\title{
Dimetil-karbonát szintézis vizsgálata különböző szén hordozós katalizátorokon
}

\author{
Doktori (Ph.D.) értekezés
}

\section{Merza Gabriella}

Témavezető:

Dr. Erdőhelyi András, professor emeritus

Környezettudományi Doktori Iskola

Természettudományi és Informatikai Kar

Fizikai Kémiai és Anyagtudományi Tanszék

SZTE TTIK

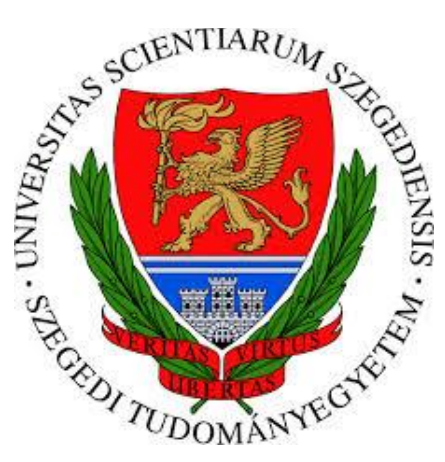

Szeged

2015 


\section{Tartalomjegyzék}

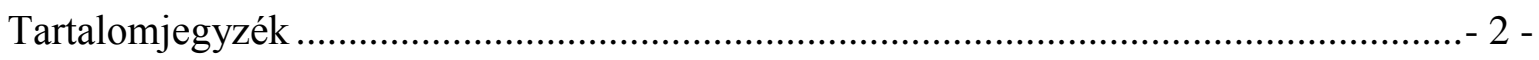

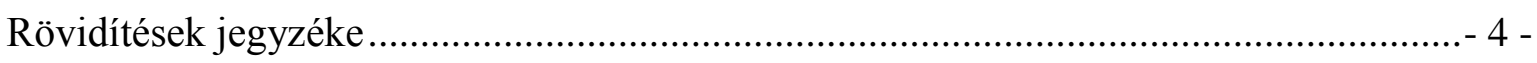

1. Bevezetés .............................................................................................. 5 -

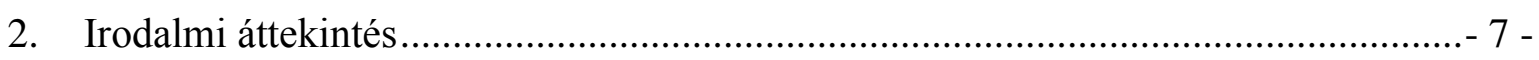

3. Kísérleti rész.......................................................................................... 21 -

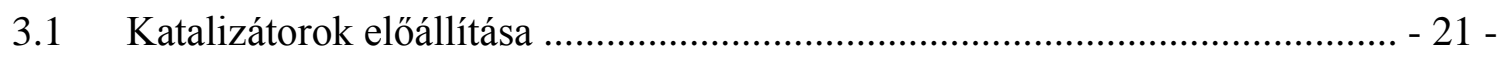

3.1.1 Fajlagos felület mérése .................................................................. - 21 -

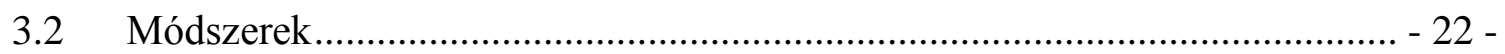

3.2.1 Katalitikus reakciók kivitelezése …................................................... - 22 -

3.2.2 Röntgen fotoelektron spektroszkópiás vizsgálatok (XPS) ...................... - 23 -

3.2.3 Infravörös spektroszkópiás vizsgálatok (IR) ..................................... - 24 -

3.2.4 DMC hőmérséklet programozott deszorpciós vizsgálatok (TPD)............ - 24 -

3.2.5 $\mathrm{NH}_{3}$ és $\mathrm{CO}_{2}$ hőmérséklet programozott deszorpciós vizsgálatok (TPD) . - 24 -

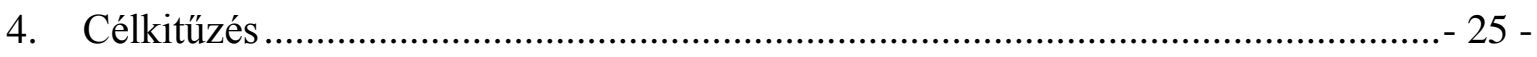

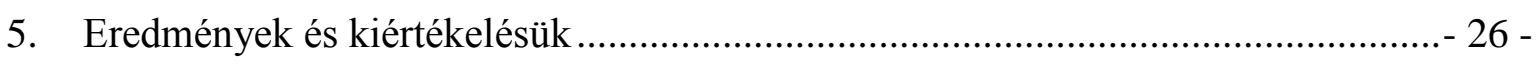

5.1 Többfalú szén nanocső hordozós katalizátorok vizsgálata ............................. - 26 -

5.1.1 Metanol oxidatív karbonilezése.......................................................... - 26 -

5.1.2 Metanol oxidációja .......................................................................... - 30 -

5.1.3 DMC katalitikus bontása ............................................................. - 31 -

5.1.4 XP spektroszkópiás vizsgálatok ....................................................... - 34 -

5.1.5 Infravörös spektroszkópiás vizsgálatok ........................................... - 40 -

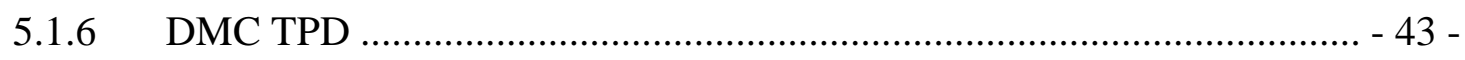

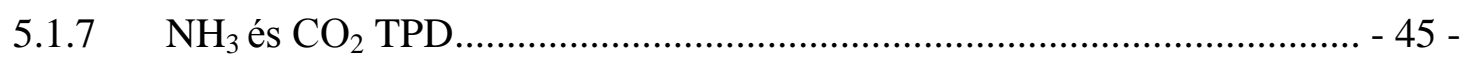

5.2 Norit hordozós katalizátorok vizsgálata.................................................. - 47 -

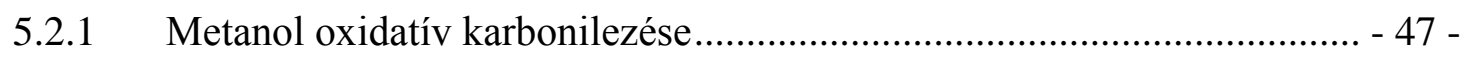


5.2.2 DMC katalitikus bontása .................................................................... - 53 -

5.2.3 XP spektroszkópiás vizsgálatok ...................................................... - 57 -

5.2.4 Infravörös spektroszkópiás vizsgálatok ................................................. - 62 -

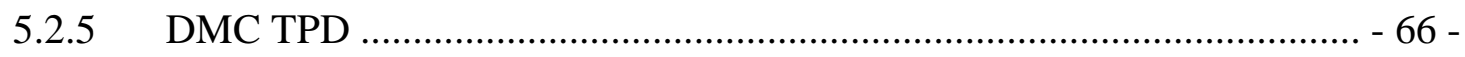

5.2.6 $\mathrm{NH}_{3}$ és $\mathrm{CO}_{2}$ TPD................................................................... 6 - 67 -

6. Eredmények kiértékelése................................................................................ 70 -

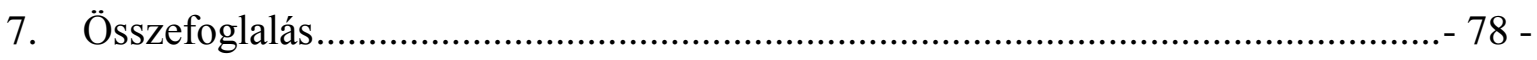

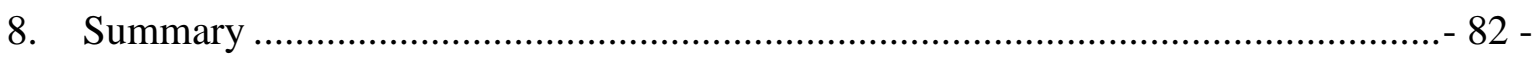

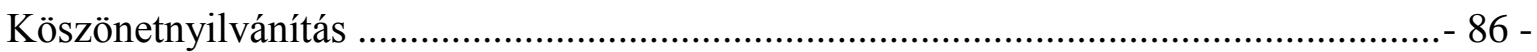

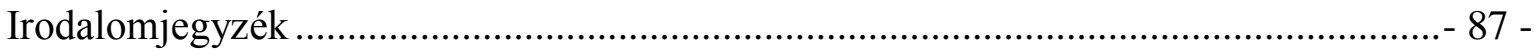




\section{Rövidítések jegyzéke}

AC - Aktív szén

DMC - Dimetil-karbonát

DME - Dimetil-éter

DMM - Dimetoxi-metán

FA - Formaldehid

FWHM - Félértékszélesség

IR - Infravörös spektroszkóp

MF - Metil-formiát

MMC - Monometil-karbonát

MWCNT - Többfalú szén nanocső

TPD - Hőmérséklet programozott deszorpció

VOC - Illékony szerves vegyületek

XPS - Röntgen fotoelektron spektroszkóp 


\section{Bevezetés}

A kémiai felfedezések, valamint az ezekből származó új technológiák és termékek bevezetésével a vegyipar meghatározó szerepe a társadalom szükségleteinek kielégítésében az elmúlt évtizedekben folyamatosan növekedett. Ennek ellenére az emberiség egy része negatívan értékeli a vegyipart, ami néhány szintetikus termék környezetre és/vagy egészségre káros hatása miatt alakulhatott ki.

A környezeti problémák forrását nem elég felderíteni és azokkal utólag foglalkozni, hanem törekedni kell olyan új vegyipari folyamatok és termékek kifejlesztésére, amelyek az egészségre és a környezetre nem lesznek károsak. A környezetbarát értékrend számos rutinszerüen használt vegyületet, módszert és technológiai megoldást elavulttá tesz, bár a célok elérése így gyakran számottevően nehezebb. A zöld kémia erre a problémára próbál megoldást találni úgy, hogy utat mutat a környezeti szempontból jobb megoldások kialakításához. A zöld kémia alapvetően a környezetszennyezés molekuláris megelőzése.

Az 1990-ben elfogadott amerikai szennyezés-megelőzési törvény a környezeti szennyezők forrásának csökkentésére helyezte a hangsúlyt. A megelőzési stratégia alapja hogy, ha egy szennyező anyag nem keletkezik, akkor az nem okozhat környezeti problémát sem. Az első zöld kémiai programot "Alternatív szintetikus utak" címmel 1991-ben indította el az Amerikai Környezeti Minisztérium, amelyet egy évvel később az Amerikai Tudományos Alap hasonló célú "Környezetbarát szintézisek és eljárások" nevü programjának meghirdetése követett. 1993-ban az Amerikai Környezeti Minisztérium hivatalos programjává vált a zöld kémia támogatása. Az Európai Közösségben először az 1993-ban Velencében megalakult konzorcium indított zöld kémiai programot. Ezt követően az Egyesült Királyságban a "Green Chemistry Network", majd Japánban a "Green and Sustainable Chemistry Network" kezdte meg müködését. 2002-ben indult el az európai COST program zöld kémiai akciója. Napjainkban számos intézmény és szervezet foglalkozik világszinten az említett témával.

A zöld kémiát mint a kémiai termékek tervezését, termelését és felhasználását irányító elvek egységes alkalmazását definiálták [1], amelynek célja a környezetre veszélyes anyagok előállításnak és felhasználásának csökkentése vagy megszüntetése. Noha az alapelvek közül számos triviálisnak tünik, együttes alkalmazásuk egy adott probléma megoldására gyakran megkívánja, hogy az alapoktól induljon egy új termék vagy folyamat 
tervezése. Ennek következtében a zöld kémia az alapkutatások jelentőségére irányítja a figyelmet. Világszerte tapasztalható fejlődése annak a felismerésnek is köszönhető, amely szerint a környezetbarát és egészségre ártalmatlan termékek és technológiák bevezetése ugyan költséges, de emellett hosszú távon mégis gazdaságos.

Szinte minden reakcióban használunk olyan segédanyagokat, amelyek elősegíthetik a kémiai reakció lejátszódását vagy a termékek elválasztását, de nem lesznek részei a termékeknek. Ez különösen igaz az oldószerekre, amelyeknek lehetnek emberre és környezetre ártalmas tulajdonságaik. Egy másik gyakori probléma, hogy egy új, látszólag egészségre és környezetre látszólag nem káros segédanyag esetleges mellékhatása lehet, hogy csak évek, évtizedek múlva jelentkezik.

Az emberiség legfontosabb célja az, hogy a civilizáció folyamatos fejlődése mellett az emberek életminősége is javuljon. A fenntartható civilizáció fontosabb megoldandó problémái között fontos szerepet játszik a környezetszennyezés lokális és globális csökkentése az energiatermelésben és a vegyiparban egyaránt. A zöld kémia e célok eléréséhez ad irányelveket, és segít hosszú távon, gazdaságosan alkalmazható (azaz fenntartható) anyagok és eljárások tervezésében.

A dimetil-karbonátot (DMC) elhanyagolható ökotoxicitása, alacsony bioakkumulációja, gyors elbomlása miatt környezetbarát vegyi anyagként tartják számon, de elöállítása során korábban veszélyes anyagok keletkeztek és/ vagy nem volt gazdaságos. Sokrétü felhasználási lehetősége miatt előállítására ipari méretü igény jelentkezik. Ennek a problémának a megoldására végzett kísérletsorozatot kutatócsoportunk, amelyben a dimetil-karbonát szintézist vizsgálta különböző szén hordozós katalizátorokon.

A DMC-ot zöld reagensként tartják számon. Alkalmazása számos lehetőséget biztosít például mérgező anyagok használatának helyettesítésére. A DMC-ot molekuláris szerkezete fontos karbonilező reagenssé teszi, mivel aktív metil, karbonil és metoxi csoportokat tartalmaz. A DMC oxigénben gazdag $(53 \mathrm{~m} / \mathrm{m} \%)$, így például oxigéntartalmú adalékként használható benzinben teljesítményjavítás és károsanyag-kibocsátás csökkentés érdekében. A DMC gyártási folyamatok és alkalmazások fejlesztésének fontosságáról tanúskodik az utóbbi évtizedben az irodalmi és a szabadalmi referenciák számbeli növekedése is. A környezetbarát feltételeknek megfelelő előállítási folyamat kialakítása azonban még mindig problémát jelent. 


\section{Irodalmi áttekintés}

Az elmúlt évtizedekben a nyilvánosság egyre nagyobb figyelmet fordít a vegyi anyagok környezeti hatásainak vizsgálatára. A vegyipari az egyik olyan gazdasági ág, amelyeknek tevékenysége során veszélyes anyagok keletkezhetnek, környezeti problémákat előidézve. A világ az utóbbi években nagy hangsúlyt fektet a környezetre veszélyes anyagok keletkezésének felszámolására. Az iparág egésze csökkentette a károsanyag kibocsátását a XX-XXI. század során, azonban továbbra is léteznek olyan eljárások, amelyek környezeti szempontokból újra értékelést, újra tervezést igényelnek. Túl sok energiát fordítunk a melléktermékek ártalmatlanitására, kezelésére vagy átalakitására. A veszélyes vegyi anyagokat felhasználó eljárások során szigorú biztonsági elöírásokat kell betartani. Nagy mennyiségü oldószert alkalmazó eljárások folyamán sok energiát kell az oldószer tisztítására és újrahasznosítására fordítani. A vonatkozó jogszabályok folyamatosan szigorodnak, ami előnyös ugyan a környezeti hatások szempontjából, de nagy anyagi terhet ró többek között az iparra. A probléma forrásának felszámolására tisztább kémiai folyamatok megtervezése adhat lehetőséget, innovatív és környezetbarát megoldásokkal, amelyre például a zöld kémia kínál kiváló lehetőségeket [2].

A zöld előállitási folyamatok föbb céljai a következőek [3]:

- a hulladék kialakulásának minimalizálása,

- mérgező és veszélyes szerek valamint segédanyagok használatának kerülése,

- a termékek könnyü biológiai lebonthatósága,

- öko-kompatibilis anyagok használata,

- energiaigény csökkentése,

- megújuló anyagok használata,

- inkább katalizátor alkalmazása, mint reagenseké sztöchiometrikus mennyiségben.

A dimetil-karbonát környezetbarát anyag, amelyre a zöld jellemzők legtöbbje igaz, így az előállitási és a felhasználási lehetősége iránt már a XX. század során érdeklődést mutattak. Az egyre növekvő figyelem kedvező tulajdonságainak köszönhető. Nem halmozódik fel a szervezetben és biológiai úton könnyen lebontható [4]. Nem mérgezö, az egyre fejlödö előállítási folyamatok ma már kerülik a foszgén használatát és szervetlen sók sem keletkeznek melléktermékként. A DMC-nak nincs irritáló vagy mutagén hatása. Ezen 
tulajdonságainak köszönhetően könnyen kezelhető különleges biztonsági feltételek nélkül [5] [6] [7].

Sokoldalúan felhasználható, a kísérleti körülményektől függően irányítható kémiai reaktivitású kétféle szén centrumának köszönhetően nukleofil reagens jelenlétében müködhet metoxi-kabonilező vagy metilező szerként is eltérő reakcióhőmérsékleteken. Elsősorban metoxi-kabonilező szerként viselkedik, ahol a nukleofil reagens a DMC karbonil csoportjának szenével reagál, így például foszgén helyettesítésére alkalmas. Magasabb hőmérsékleten (433 K) metilező szerként viselkedik, ahol a nukleofil reagens a DMC metil csoportjával reagál. Mivel mind a metilációs mind a metoxi karbonilezési reakció közben metoxi csoport $\left(\mathrm{CH}_{3} \mathrm{O}^{-}\right)$keletkezik, mindkét reakció kivitelezhető bázis jelenlétében. Így a melléktermékek, például a szervetlen sók keletkezése elkerülhető, valamint a kapcsolódó elhelyezési és ártalmatlanítási problémák is megszünnek. A reakció alatt keletkezett metanol közvetlenül újrahasznosítható a DMC elöállítására [5] [8] [9].

Aromás polikarbonátok foszgénmentes előállítása jól kivitelezhető DMC felhasználásával [10]:

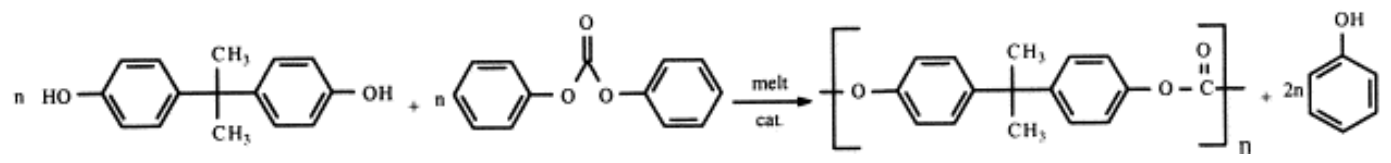

Ez a folyamat egyidejüleg mellőzi a foszgén használatát reaktánsként, a metilén-kloridot oldószerként, és a nátrium-klorid képződését a hagyományos előállítási móddal szemben, megfelelö iránymutatást adva a zöld kémiának [9] [5].

Az előállítási folyamat köztiterméke a difenil-karbonát (DPC), amely a DMC és fenol között lezajló átészterezö-diszproporcionálási folyamat eredménye [7]:

$$
\begin{gathered}
\mathrm{PhOH}+\left(\mathrm{CH}_{3} \mathrm{O}\right)_{2} \mathrm{CO} \stackrel{\mathrm{Ti}(\mathrm{OPh})_{4}}{\rightarrow} \mathrm{PhO}(\mathrm{CO}) \mathrm{OCH}_{3}+\mathrm{CH}_{3} \mathrm{OH} \\
2 \mathrm{PhO}(\mathrm{CO}) \mathrm{OCH}_{3} \stackrel{\mathrm{Ti}(\mathrm{OPh})_{4}}{\rightarrow} \mathrm{C}(\mathrm{PhO})_{2} \mathrm{CO}+\left(\mathrm{CH}_{3}\right) \mathrm{O}_{2}
\end{gathered}
$$

Az izocianát foszgénmentes előállítása a megfelelő karbamát termolízisén keresztül történik. Karbamát szintézisére számos eljárás létezik. Ezek közül a DMC vagy DPC reakciója alifás aminokkal egy igen hatékony módszer [7] [11]. 
Acetát-észterek és ketonok helyettesítésére is alkalmazható a DMC, mivel oldószerként is kiválóan viselkedik. Vízmentes elektrolit komponensként egyre inkább használják lítium akkumulátorokban. További példa habosító anyagként való alkalmazása poliuretán habban [5] [10].

Az elmúlt években a jármüvek károsanyag kibocsátásnak csökkentése kapcsán is felmerült a DMC alkalmazása. Ez annak köszönhető, hogy kiemelkedően magas a DMC molekula oxigén tartalma $(53,3 \mathrm{~m} / \mathrm{m} \%)$ valamint kiváló az elegyedési hajlama. A DMC esetleges felhasználása az üzemanyagokban a légkörre kifejtett hatásának tanulmányozásához is hozzájárult. Bebizonyosodott, hogy a fotokémiai ózontermelő tulajdonága (POCP) elhanyagolható a hagyományos üzemanyag adalékokkal szemben. Ilyen jellegü alkalmazása környezetvédelmi szempontból is biztonságos lenne, valójában a DMC igen alacsony POCP tulajdonságú anyag az oxigéntartalmú illékony szerves vegyületek között [12] [10].

Azokat a vegyi folyamatokat, amelyek a környezetre nézve nagy terhelést jelentenek, célszerü módosítani vagy környezetkímélőbb folyamatokkal helyettesíteni. A nagy mennyiségü melléktermék keletkezésével járó folyamatok szelektív reakciók használatával kiválthatóak. A megfelelő előállítási mód kiválasztása során a fő szempont nem csak a kívánt termék előállítása, hanem a környezetbarát megközelítés is fontos. Ebben a tekintetben a megfelelő szelektív reakció mellett az alkalmas katalizátor megválasztásának is nagy jelentősége van [13].

Az 1980-as évekig a DMC előállításának alapja a mérgező és veszélyes foszgén volt [10] [14]. A reakciót két lépésben kivitelezték, amely során a foszgént reagáltatták metanollal, metil-(klór-formiát) köztiterméken keresztül képzödött a DMC [6]:

$$
\begin{gathered}
\mathrm{COCl}_{2}+\mathrm{CH}_{3} \mathrm{OH} \rightarrow \mathrm{ClCOOCH}_{3}+\mathrm{HCl} \\
\mathrm{ClCOOCH}_{3}+\mathrm{CH}_{3} \mathrm{OH} \rightarrow\left(\mathrm{CH}_{3} \mathrm{O}\right)_{2} \mathrm{CO}+\mathrm{HCl}
\end{gathered}
$$

A reakció 273 K-en vízmentes oldószerben piridin vagy szervetlen bázis felesleg mellett ment végbe azért, hogy a reakcióegyensúlyt a DMC szintézis felé tolják el. Ezzel az elöállítási folyamattal ugyan magas DMC hozamot értek el, a foszgén mint reagens valamint a nagy mennyiségü piridin semlegesítése és a keletkező $\mathrm{NaCl}$ eltávolításának 
szükségessége azonban erőteljesen szabályozott és drága szintézis utáni tisztítási folyamatokat igényelt.

Az Enichem által kifejlesztett folyadék fázisú metanol oxi-karbonilezése már egy katalitikus előállítási mód [15], amely a következő egyenleten alapszik:

$$
2 \mathrm{CH}_{3} \mathrm{OH}+\mathrm{CO}+0,5 \mathrm{O}_{2} \stackrel{\mathrm{CuCl}}{\rightarrow}\left(\mathrm{CH}_{3} \mathrm{O}\right)_{2} \mathrm{CO}+\mathrm{H}_{2} \mathrm{O} \quad \Delta H r_{(773 \mathrm{~K})}=-318 \mathrm{~kJ} / \mathrm{mol}
$$

A módszer egy olyan iparosított folyamatra épült, amely a $\mathrm{CuCl}$ katalitikus tulajdonságait használta ki a reakcióban. A módszer azonban fokozatosan háttérbe szorult. A termékek elválasztása a katalizátortól valamint a reakció közben keletkező $\mathrm{HCl}$ problémát jelentett $[16]$.

Gáz fázisú DMC előállítására fejlesztették ki a metil-nitrit karbonilezési eljárást [17]. Az első lépésben a metil-nitritet állították elö [7]:

$$
2 \mathrm{CH}_{3} \mathrm{OH}+2 \mathrm{NO}+0,5 \mathrm{O}_{2} \rightarrow 2 \mathrm{CH}_{3} \mathrm{ONO}+\mathrm{H}_{2} \mathrm{O}
$$

A következő lépéshez a rendszerből eltávolították a vizet, így a DMC szintézis teljesen vízmentes közegben mehetett végbe. A második lépés a metil-nitrit és a szénmonoxid gőzfázisú katalitikus reakciója volt, amelyhez aktív szén hordozós $\mathrm{PdCl}_{2}$ katalizátort használtak:

$$
\mathrm{CO}+2 \mathrm{CH}_{3} \mathrm{ONO} \stackrel{\mathrm{PdCl}_{2}}{\rightarrow} \mathrm{CO}\left(\mathrm{OCH}_{3}\right)_{2}+2 \mathrm{NO}
$$

Az eljárás előnye, hogy külön kezeli a vizet, a metanolt és a DMC-ot, ami más előállítási módszereknél általában elválasztási problémákat okozott, a három termék között kialakuló azeotróp egyensúly miatt. Az eljárás kialakítása során több katalizátort teszteltek, mint például a fentiekben említett $\mathrm{CuCl}$-ot, amely azonban alacsony aktivitást mutatott [18]. Többféle hordozó hatását is nyomon követték a reakció folyamán. A kapott eredmények alapján az aktív szén hordozó bizonyult katalitikusan a legaktívabbnak, specifikus fajlagos felülete és porózus jellege nagyban megnövelte a teljesítményt. Megállapították, hogy a katalizátor sav-bázis karaktere fontos szerepet játszott a folyamat során.

A DMC direkt szintézise $\mathrm{CO}_{2}$-ot használ szénforrásként. Az eljárás egyidejűleg célozza meg a környezetvédelmi és a hatékony kémiai szintézis feltételeinek elérését. Előnye nem csak az, hogy csökkenti a légkörbe kibocsátott $\mathrm{CO}_{2}$ mennyiségét, és az ebből eredő környezetvédelmi problémákat, hanem igen olcsó és könnyen elérhető alapanyag is. 
A DMC direkt szintézisét $\left(\mathrm{CO}_{2}\right.$ és metanol reakciója) már az 1980-as évek óta tanulmányozzák [19]:

$$
2 \mathrm{CH}_{3} \mathrm{OH}+\mathrm{CO}_{2} \leftrightharpoons \mathrm{CO}_{2}\left(\mathrm{OCH}_{3}\right)_{2}+\mathrm{H}_{2} \mathrm{O}
$$

$\mathrm{Az}$ eljárásban rejlő lehetőségek ellenére a $\mathrm{CO}_{2}$ aktiválása nehézségekkel járt termodinamikai stabilitásának és kinetikus inertségének köszönhetően. A katalizátor esetleges bomlásából származó káros anyagok valamint a karbonát hidrolízise is hátrányosan befolyásolhatják a reakciót. Külön kutatási terület alakult ki a problémák megoldására, vizsgálva a különböző katalizátorokat, dehidratáló szereket, reakciókörülményeket és kivitelezési lehetőségeket. A termodinamikai korlátok feloldására megoldást jelent például a reakcióegyensúly eltolása a nyomás növelésével, hatékony vízelvonó szerek használatával valamint a megfelelő katalizátorok kifejlesztésével. Széles körben vizsgálták a katalizátorok alkalmasságát. $\mathrm{K}_{2} \mathrm{CO}_{3}$ [20], $\mathrm{ZrO}_{2}$ [21] [22], $\mathrm{H}_{3} \mathrm{PW}_{12} \mathrm{O}_{4}$ $\mathrm{ZrO}_{2}[23]$ ) katalizátorok alkalmazása esetén a DMC képződési sebessége alacsony volt, még szuperkritikus körülmények vagy adalékanyagok használata mellett is. $\mathrm{CeO}_{2}$-ot [24] [25], $\mathrm{SiO}_{2}$ és VSO $\left(\mathrm{V}_{2} \mathrm{O}_{5}-\mathrm{SiO}_{2}\right)$ hordozós $\mathrm{Cu}-(\mathrm{Ni}, \mathrm{V}, \mathrm{O})$ és $\mathrm{Cu}-\mathrm{Ni}$ rendszereket [26] [27] valamint különböző szerkezetü aktív szén hordozós Cu-Ni kétfémes rendszereket [28] [29] [30] is tanulmányoztak.

A szén-dioxid reagál a metanollal bázikus jellegü katalizátor $\left(\mathrm{K}_{2} \mathrm{CO}_{3}, \mathrm{~K}_{3} \mathrm{PO}_{4}\right)$ és metiljodid promóter jelenlétében [20], amely során dimetil-karbonát keletkezik nagy nyomású rendszerben. Megfigyelések alapján a katalizátor bázicitása a meghatározó a folyamat során, a karbonát ionokkal szemben. A szerves bázisok hatékonysága rávilágított arra a tényre, hogy a karbonát sók közötti reaktivitásbeli differencia a különböző méretü alkálifém-ionok által indukált eltérő bázikusságnak tulajdonítható. A reakció útvonalát, amely magában foglalja a metanol aktiválását, a szén-dioxid beékelődését és a dimetilkarbonát képződését, a következőképpen írták le [20]:

$$
\begin{gathered}
\mathrm{CH}_{3} \mathrm{OH}+\text { Bázis } \rightarrow \mathrm{CH}_{3} \mathrm{O}^{-}+\mathrm{H}^{+} \text {- - - Bázis } \\
\mathrm{CO}_{2} \rightarrow\left[\mathrm{CH}_{3} \mathrm{OC}(\mathrm{O}) \mathrm{O}\right]^{-}+\mathrm{H}^{+}-\text {- - Bázis } \\
\mathrm{CH}_{3} \mathrm{I} \rightarrow \mathrm{CH}_{3} \mathrm{OC}(\mathrm{O}) \mathrm{OCH}_{3}+\mathrm{HI}+\text { Bázis }
\end{gathered}
$$

A DMC előállítása metanol és $\mathrm{CO}_{2}$ reakciójával $\mathrm{ZrO}_{2}$ katalizátoron nagy szelektivitással kivitelezhető. A DMC képződési sebességét nagyban befolyásolta az előállítási folyamat 
során változtatott paraméterek miatt kialakuló különböző $\mathrm{ZrO}_{2}$ szerkezet. A katalitikus aktivitást a $\mathrm{ZrO}_{2}$ felületen lévő sav-bázis helyekkel hozták összefüggésbe az $\mathrm{NH}_{3}$ és a $\mathrm{CO}_{2}$ TPD eredmények alapján. Az elöállítási folyamat gyenge pontja az, hogy a konverzió mértékét korlátozza az érzékeny reakcióegyensúly. A rendszerben a reakció folyamán keletkező víz eltávolításával (például trimetil-ortoformiát alkalmazásával) azonban az eredmény pozitív irányba befolyásolható [21].

Vizsgálták a reakciót $\mathrm{H}_{3} \mathrm{PW}_{12} \mathrm{O}_{4}-\mathrm{ZrO}_{2}$ katalizátoron is. A katalizátor elöállítása során alkalmazott kezelések a kompozit elsődleges Keggin szerkezetét nem befolyásolták, a kompozit egyaránt tartalmazott Brönsted és Lewis savas helyeket. A DMC direkt szintézise leginkább a $\mathrm{CO}_{2}$ nyomástól függött. A Brönsted savas helyeket a kompozitban a metanol aktiválásához, a $\mathrm{ZrO}_{2}$ hordozó hatását pedig a katalitikus aktivitás erősítéséhez rendelték [23].

A különböző fémsók, mint például $\mathrm{ZrO}_{2}$ [21], $\mathrm{ZrO}_{2}-\mathrm{CeO}_{2}$ [31] alkalmazásának célja hatékony katalitikus rendszerek kiépítése volt. A fö probléma ezekben az esetekben a viszonylag kis fajlagos felület, a magas beszerzési költség, az alacsony katalitikus aktivitás vagy a rövid élettartam volt.

A DMC direkt szintézisében használt különböző $\mathrm{CeO}_{2}$ katalizátorok vizsgálata rámutatott, hogy az aktív hely a reakció szempontjából egy stabil kristály felület, mint például a $\mathrm{CeO}_{2}$ (111) [25]. A Ce(IV) használata esetében a katalizátor élettartamának és stabilitásának vizsgálata során a dezaktiválódást kiváltó oknak a Ce redukálódást és a felület módosulását tartották. A különböző fémek eltérő stabilizációs hatást gyakoroltak a Ce katalizátor aktivitására. Az $\mathrm{Al}$ adalékolás stabilizálta a katalizátort és többször használatát tette lehetővé dezaktiválódás nélkül, akár több cikluson keresztül is. A részecskék méreteloszlása is meghatározó volt, 15-60 nm között a legaktívabbak, míg a mikrométeres méretű részecskék már sokkal kevésbé azok [24].

Új V-O-Si kötés jött létre, amikor $\mathrm{V}_{2} \mathrm{O}_{5}$-ot vittek fel $\mathrm{SiO}_{2}$-ra. $\mathrm{A} \mathrm{V}_{2} \mathrm{O}_{5}$ kristályszerkezet változatlan maradt a VSO felületen, de megváltozott, amikor a $\mathrm{CuO}-\mathrm{NiO} / \mathrm{VSO}-$ ot redukálták $\mathrm{Cu}-\mathrm{Ni} / \mathrm{VSO}$-dá. A metanol és $\mathrm{CO}_{2}$ a katalizátorra adszorbeáltatva aktiválódott a DRIFT spektrumok alapján. A katalizátorok kristályossága kismértékben ugyan, de befolyásolta a DMC szintézist. A reakcióhőmérséklet növelésével nagyobb lett a $\mathrm{CH}_{3} \mathrm{OH}$ 
konverzió, azonban $413 \mathrm{~K}$ felett a DMC kitermelés csökkeni kezdett. A DMC szelektivitása csökkent $400 \mathrm{~K}$ felett a DMC bomlásának köszönhetően [27].

Bian és munkatársai a DMC direkt szintézisének vizsgálata során többféle aktív szén hordozós $\mathrm{Cu}-\mathrm{Ni}$ katalizátor alkalmasságát tesztelték: többfalú szén nanocső (MWCNT) hordozós [28], hőkezelt grafithordozós (TEG) [29], grafén alapú nanolap (GNS) [30], vanádium adalékolt aktív szén (AC) [32], AC kompozit [33], grafit nanokompozit [34] rendszereket vizsgáltak. A jó katalitikus aktivitást a fém réz és nikkel szinergikus hatásának, a $\mathrm{Cu}-\mathrm{Ni}$ ötvözet $\mathrm{CH}_{3} \mathrm{OH}$ és $\mathrm{CO}_{2}$ aktiválására gyakorolt hatásának, a fém részecskék megfelelő felületi eloszlásának valamint a szén hordozók sajátos jellemzőinek (mint például speciális morfológiájuk, mikro- és mezoporózusos szerkezetük, változó pórusméret eloszlásuk) tulajdonították.

Az MWCNT hordozós Cu-Ni kétfémes katalizátort optimális reakciókörülmények között (393 K és 1,2 MPa) igen hatékony katalizátornak találták. A metanol legmagasabb konverziója több mint 4,3\%, a DMC szelektivitása 85\% körüli volt [28].

A $\mathrm{CuCl}_{2} / \mathrm{AC}$ katalizátor esetében $\mathrm{Cu}^{0}, \mathrm{Cu}^{+}$és $\mathrm{Cu}^{2+}$ egyszerre voltak jelen a felületen a DMC direkt szintézisben, amelyeket a DMC képződés aktív centrumaiként határoztak meg. A katalizátor kalcinálása maximalizálta a $\mathrm{Cu}^{+}$és $\mathrm{Cu}^{2+}$ mennyiségét a mintán, így a $\mathrm{CuCl}_{2} / \mathrm{AC}$ katalizátor aktivitását is [35].

A DMC előállítására kialakított ipari méretű technológiák több hátránya ismert. Az Enichem által kifejlesztett folyamatban, a nagy mennyiségü réz(I)-klorid sósav képződéséhez vezet. A metil-nitrit karbonilezési folyamat gazdaságosabbnak tünik. Bár nem termelödik nagy mennyiségü $\mathrm{CO}_{2}$ és nagyobb a DMC hozam, viszont a folyamat biztonsági problémákat vet fel. A $\mathrm{Pd} / \mathrm{NO} / \mathrm{O}_{2}$ keverék használata robbanásveszélyes, a metil-nitrit pedig erősen toxikus. Ha a koncentrációja meghaladja az 50 ppm-t, okozhat hányingert és eszméletvesztést, a metil-nitrit mérgezőbb a szén-monoxidnál. A DMC direkt szintézise során elért eredmények figyelemre méltóak, mégis a $\mathrm{CO}_{2}$ termodinamikai stabilitásából és kinetikus inertségéből fakadó korlátok feloldása nagy energia befektetést igényel [31].

A hátrányok miatt a gőzfázisú metanol oxidatív karbonilezése felé fordultak a kutatások, amely közvetlenül származtatható a folyadék fázisú Enichem módszerből: 


$$
2 \mathrm{CH}_{3} \mathrm{OH}_{(\mathrm{g})}+\mathrm{CO}_{(\mathrm{g})}+0,5 \mathrm{O}_{2(\mathrm{~g})} \rightarrow\left(\mathrm{CH}_{3} \mathrm{O}\right)_{2} \mathrm{CO}_{(\mathrm{g})}+\mathrm{H}_{2} \mathrm{O}_{(\mathrm{g})}
$$

A folyamat során dimetil-éter (DME), metil-formiát (MF) és dimetoxi-metán (DMM) képződik az alábbi egyenletek szerint [36]:

$$
\begin{gathered}
2 \mathrm{CH}_{3} \mathrm{OH}_{(\mathrm{g})} \rightarrow \mathrm{CH}_{3} \mathrm{OCH}_{3(\mathrm{~g})}+\mathrm{H}_{2} \mathrm{O}_{(\mathrm{g})} \\
2 \mathrm{CH}_{3} \mathrm{OH}_{(\mathrm{g})}+\mathrm{O}_{2(\mathrm{~g})} \rightarrow \mathrm{HCOCCH}_{3(\mathrm{~g})}+2 \mathrm{H}_{2} \mathrm{O}_{(\mathrm{g})} \\
3 \mathrm{CH}_{3} \mathrm{OH}_{(\mathrm{g})}+0,5 \mathrm{O}_{2(\mathrm{~g})} \rightarrow\left(\mathrm{CH}_{3} \mathrm{O}\right)_{2} \mathrm{CH}_{2(\mathrm{~g})}+2 \mathrm{H}_{2} \mathrm{O}_{(\mathrm{g})}
\end{gathered}
$$

A metanolt párologtató kamrán keresztül injektálták álló ágyas reaktorra a szénmonoxiddal és az oxigénnel egyetemben. A reakciót rendszerint 373-403 K közötti hőmérsékleten, nyomás alatt (10-30 bar) kivitelezték. Az állandó hőmérséklet tartása fontos tényezö, mivel a szén-monoxid nem-katalitikus oxidációja is végbe mehet magasabb hőmérsékleteken.

A katalizátor a reaktor belsejében található általában, amely valamilyen hordozóra (aktív szén, zeolit, stb.) felvitt aktív fázis. Sokféle katalizátor alkalmasságát vizsgálták és szabadalmaztatták erre a reakcióra [37] [38] [39].

Például Zheng munkája nyomán a $\mathrm{CuCl}_{2} / \mathrm{SiO}_{2}-\mathrm{ZrO}_{2}$ ígéretes katalizátorként viselkedett a metanol oxidatív karbonilezése során, figyelemre méltó eredményeket ért el a DMC szelektivitást és metanol konverziót tekintve [40].

A $\mathrm{SiO}_{2}-\mathrm{TiO}_{2}$ hordozós $\mathrm{CuCl}$ is kiváló katalitikus aktivitást mutatott ebben a reakcióban. A klaszter modelleken végzett kvantumkémiai számítások azt jelezték, hogy a $\mathrm{CuCl}$ molekulák és a Si-O-Ti kötések között létrejött kölcsönhatások viszonylag erösen kötött Okomplexek képzödéséhez vezettek. Ezekben a Si-O-Ti kötésekben az összekötő oxigénatomok elektrondonorként funkcionálnak a $\mathrm{CuCl}$ központi réz ionja számára [41].

Sokféle hordozó leírása megtalálható az irodalomban, amelyek között a zeolitok kiemelkedő szerepet kapnak a DMC szintézisben. Kiváló kationcserélő tulajdonságuk előnyös a katalitikus reakciók során. Felhasználásuk igen elterjedt, többek között rézioncserélt zeolitokat sikeresen alkalmaztak katalizátorként nitrogén-oxid szelektív redukciójára [42] [43], gázolaj kéntelenítésére [44] vagy akár adszorbensként is [45]. Csak a XXI. században vált azonban jellemzővé a réz-ioncserélt zeolitok használata DMC szintézis során. 
1996-ban King írta le elsőként, hogy a réz-ioncserélt Y zeolit savas formája (HY-nak nevezte) aktív katalizátora a gőzfázisú metanol oxidatív karbonilezésének 403 K-en. Tapasztalatai szerint a $\mathrm{Cu}(\mathrm{I}) \mathrm{Y}$ nagyobb hatásfokot és kisebb dezaktiválódást mutatott, mint a szén hordozós $\mathrm{CuCl}_{2}$ katalizátor. Ezzel szemben az ioncserélt $\mathrm{Cu}(\mathrm{II}) \mathrm{Y}$ nagyon alacsony aktivitású volt ugyanebben a reakcióban [46].

King munkája nyomán a zeolit hordozós katalizátorok használata igen gyakorivá vált. Richter és társai $\mathrm{Y}$ zeolit hordozós réz katalizátort sikeresen alkalmaztak DMC előállítására. Metanol oxidatív karbonilezése során 413-443 K hőmérséklet tartományban 70-75\%-os DMC szelektivitást értek el, 5-12\%-os metanol konverzió mellett nagy nyomáson (0,4-1,6 MPa) [47] [48].

Nam és munkatársai egy új reakció rendszert alkalmaztak Cu-alapú katalizátor jelenlétében. Számos hordozó alkalmasságát vizsgálták, azonban az Y zeolit mutatta a legjobb katalitikus eredményeket. A promóterek hatását is tanulmányozták, végezetül a következő sorrendet állították fel az aktivitások alapján [49]:

\section{$\mathrm{CuCl}_{2}>\mathrm{Cu} / \mathrm{Na} / \mathrm{Y}$ zeolit $>\mathrm{Cu}(\mathrm{OH})_{2}$}

A $\mathrm{Cu}^{+} \mathrm{X}$ és $\mathrm{Cu}^{+} \mathrm{ZSM}-5$ zeolit hordozós katalizátorokon végzett kísérletek szerint a katalizátor felületén végbemenő erős $\mathrm{CO}$ adszorpció nem függ össze a megnövekedett DMC hozammal. Anderson és Root szerint a képződési sebesség meghatározó eleme a szintézis során a gáz fázisú CO reakciója a felületi metoxi csoportokkal [50] [51].

Metanol oxidatív karbonilezését Cu-ZSM-5 katalizátoron Bell és munkatársai is vizsgálták. A DMC szintézis során két féle réz kationt határoztak meg a katalizátor felületén. Az egyiket metanol borította, a másikon $\mathrm{CO}$ és metanol együttesen adszorbeálódott. Megállapították, hogy a CO jelenléte mindenképp szükséges a DMC kialakulásához [52].

$\mathrm{A} \mathrm{Cu} \mathrm{Y} \mathrm{zeolit} \mathrm{katalizátoron} \mathrm{az} \mathrm{erősen} \mathrm{diszpergált} \mathrm{CuCl}$ és az ioncserélt $\mathrm{Cu}^{+}$is aktívnak bizonyult a $\mathrm{DMC}$ szintézis során. $\mathrm{A} \mathrm{CuCl}$ és a $\mathrm{CuCl}_{2}$ párhuzamosan jelen volt a katalizátor külső felületén, amíg az Y zeolit belső szerkezete ioncserélt $\mathrm{Cu}^{+}-\mathrm{t}$ vagy kis mennyiségü adszorbeált CuCl-ot tartalmazott [53].

Újabban széntartalmú anyagokat használnak hordozóként katalitikus reakciókban kiváló szerkezeti, mechanikai, kémiai, egyedi elektromos vezetőképességi tulajdonságaik miatt [54]. A heterogén katalízisben már régóta alkalmaznak szén hordozós katalizátorokat [55]. 
Számos szén fajtát használtak erre a célra, például: aktív szenet, aktivált szénszálat, grafitot, kormot, grafit vegyületeket és a szén nanocsöveket [55] [56] [57] [58].

Norit típusú aktív szenet használva hordozóként többféle katalitikus reakciót sikeresen hajtottak végre korábban is. Solymosi és munkatársai $\mathrm{Mo}_{2} \mathrm{C} /$ Norit katalizátoron vizsgálta a metanol bomlását és a gőz reformálását [59], az etanol bomlását [60] valamint a dimetiléter (DME) bomlását és gőzreformálását [61]. Marban és munkatársai Norit hordozós Rh katalizátoron vizsgálták a metanol bomlást [62], Tolmacsov és munkatársai Pt/Norit katalizátoron tanulmányozták a metanol bomlását és gőz reformálását [63].

Az aktív szén különböző fajtái egyre gyakrabban használt hordozók a gőzfázisú metanol oxidatív karbonilezésében is, fóként a Cu katalizátorok esetében.

A CuCl/AC katalizátor a metanol oxidatív karbonilezése során nagy aktivitást mutatott. A kutatások alapján egyértelmüvé vált, hogy a $\mathrm{CuCl}_{3}{ }^{2-}$ felületi formák a reakció közben a $\mathrm{Cu}^{0}$ irányba tolódtak. A réz-klorid aktív volt a DMC előállításában [64].

Az aktív szén hordozós $\mathrm{CuCl}_{2}$ katalizátoron optimális körülmények között $(7 \mathrm{~m} / \mathrm{m} \% \mathrm{Cu}$ tartalom, 673 K kalcinálási hőmérséklet, 12 MPa nyomás és 393 K reakcióhőmérséklet $1 \mathrm{~g}$ katalizátort használva) a DMC képződési sebessége elérte a 4,77 mmol/órát. A DMC képződési sebessége összefüggésben állt a $\mathrm{Cl} / \mathrm{Cu}$ aránnyal. A felületen a réz-klorid és a metanol reakciójából egy $\mathrm{Cu}-\mathrm{Cl}-\mathrm{OH}$ forma keletkezett, amely réz-oxikloriddá alakult a reakció előrehaladtával. A $\mathrm{CO}_{2}$-nak, mint a metanol oxidatív karbonilezési reakció melléktermékének, a képződési sebessége magasabb volt abban az esetben, amikor a $\mathrm{CuCl}_{2} / \mathrm{AC}$ katalizátoron a réz-oxiklorid nagyobb mennyiségben volt jelen, mint a $\mathrm{Cu}-\mathrm{Cl}$ $\mathrm{OH}$ forma. Megállapították, hogy a $\mathrm{Cu}-\mathrm{Cl}-\mathrm{OH}$ forma fenntartása a felületen elösegítheti a szelektívebb DMC képződést [65].

Ren és munkatársai megfigyelték [66], hogy az aktiválási hőmérséklet a keményítő alapú szén hordozós $\mathrm{Cu}$ katalizátor használata során jelentősen befolyásolta a minta aktivitását. A hőmérséklet változtatása különböző hatást fejtett ki a mintára, a fajlagos felület, a mikropórus-térfogat és a teljes pórustérfogat is megváltozott, különböző hatékonyságot eredményezve.

A $\mathrm{CuCl}_{2} / \mathrm{NaOH} / \mathrm{AC}$ katalizátor optimális reakcióhőmérsékletét 393-403 $\mathrm{K}$ között határozták meg. A $\mathrm{CuCl}_{2} / \mathrm{NaOH} / \mathrm{AC}$ katalizátor $(\mathrm{OH} / \mathrm{Cu}=0,5-1,0$ mólaránnyal $)$ volt a 
leghatásosabb. Megállapították, hogy a katalitikus aktivitás megnövekedett a $\mathrm{OH} / \mathrm{Cu}$ mólarány növelésével a $\mathrm{CuCl}_{2} / \mathrm{AC}$-hez képest [67]. A morfológiai elemzés során két kristályszerkezetet azonosítottak a katalizátor felületén: rombos és romboéderes szerkezeteket. Az utóbbi kedvezőbb volt a DMC szintéziséhez [68].

A kókusz héj alapú aktív szén hordozót salétromsavas kezelés után nano réz heterogén katalizátor előállításához használták. A salétromsav lényegesen nem változtatta meg az AC fajlagos felületét és szerkezeti tulajdonságát. A katalizátor savas tulajdonságáért felelős oxigén tartalmú csoportok - mint például a lakton, karboxil- és fenol csoportok- azonban kialakultak az AC felületen a savas kezelés alatt, és mennyiségük a salétromsav koncentrációval párhuzamosan növekedett. A több felületi oxigénezett csoport nem csak a $\mathrm{Cu}$ diszperzióját befolyásolta, hanem a réz vegyérték eloszlását is. $\mathrm{A} \mathrm{Cu} / \mathrm{AC}$ katalizátort különböző töménységü $\mathrm{HNO}_{3}$-val kezelték a reakció előtt. Amikor a $\mathrm{HNO}_{3}$ koncentrációja $4 \mathrm{M}$ alatt volt, a megnövekedett mennyiségü felületi oxigénezett csoportokhoz kötődött a réz. Amikor a $\mathrm{HNO}_{3}$ koncentráció $4 \mathrm{M}$ felett volt, több instabil karboxil csoport keletkezett a felületen és a réz ezekhez kötött. Hökezelés hatására ezek elbomlottak, ami a viszonylag nagy réz részecskék kialakulását okozhatta. A nagy mennyiségü felületi oxigénezett csoport elősegíti a $\mathrm{Cu}^{2+}$ redukcióját és a $\mathrm{Cu}^{+} / \mathrm{Cu}^{0}$ aránya is nőtt az említett csoportok mennyiségének növekedésével. A DMC kitermelés akkor volt a legnagyobb, amikor 4 Mos töménységü $\mathrm{HNO}_{3}$-at alkalmaztak. Ezt annak tulajdonították, hogy ebben az esetben volt a legmagasabb a $\mathrm{Cu}^{+}$és a $\mathrm{Cu}^{0}$ diszperziója [69].

Az aktív szén hordozóra impregnált $\mathrm{CuCl}_{2}$ katalizátor röntgen diffrakciós spektruma a rézkloridhoz rendelhető diffrakciós csúcsok teljes hiányát mutatta $10 \mathrm{~m} / \mathrm{m} \%$-nál alacsonyabb koncentrációjú minták esetében. A magasabb $\mathrm{Cu}$ koncentrációjú mintáknál megfigyelt diffrakciós csúcsok megfeleltethetőek voltak a réz-kloridnak [70]. A diffrakciós csúcsok hiányát alacsony koncentráció esetén az aktivált réz kedvező diszperziójához rendelték a szén felületen. $\mathrm{A} \mathrm{Cl} / \mathrm{Cu}$ mólarány a katalizátor impregnálása és a szárítási folyamat után általában alacsonyabb volt, mint az elméleti érték (2), bár közelített a 2-höz a réz mennyiségének növelésével [65] [71]. Kriventsov és munkatársai a szárítás utáni klorid veszteség lehetséges magyarázatát kapcsolatba hozták a réz(II)-klorid és az oxigénezett aktív szén felületi csoportjainak kölcsönhatásával (AC-COOH és C-OH), amely sósav képződéséhez vezetett [72].

$$
\mathrm{AC}-\mathrm{COOH}+\mathrm{CuCl}_{2} \rightarrow \mathrm{AC}-\mathrm{COOCuCl}+\mathrm{HCl}
$$




$$
\mathrm{AC}-\mathrm{OH}+\mathrm{CuCl}_{2} \rightarrow \mathrm{AC}-\mathrm{OCuCl}+\mathrm{HCl}
$$

Amikor a réz tartalom kisebb volt, mint $5 \mathrm{~m} / \mathrm{m} \%$, a réz föként az aktív szén oxigénezett felületi csoportjaihoz kapcsolódott (a $\mathrm{CuCl}$ sztöchiometriának megfelelően), amíg magasabb réztartalom esetén többrétegü borítottság alakult ki $\left(\mathrm{a} \mathrm{Cu}_{2} \mathrm{Cl}\right.$ sztöchiometriának megfelelően). Yamamoto és munkatársai rámutattak, hogy a $\mathrm{Cu}(\mathrm{I})$ iont három klór atom koordinálta a katalizátor felületén $1,2 \mathrm{~m} / \mathrm{m} \% \mathrm{Cu}$ tartalom esetében. A szén felületen megjelenő karboxil- és hidroxilcsoportokat redukáló centrumoknak tekintették, amelyek elösegítették a $\mathrm{Cu}(\mathrm{II}) \mathrm{Cl}_{2}$ redukcióját $\mathrm{Cu}(\mathrm{I}) \mathrm{Cl}$-dá [71].

Katalitikus aktivitás szempontjából, az optimális réz tartalom $5-10 \mathrm{~m} / \mathrm{m} \%$ irodalomtól függően. Han és munkatársai 21\%-os metanol konverzió és 80\%-os DMC szelektivitást értek el $5 \mathrm{~m} / \mathrm{m} \%$-os a réz tartalom felett [67]. Ezzel ellentétben Punnoose arról számolt be, hogy az aktivitás a réztartalom növelésével együtt növekedett [73]. Megfigyelték, hogy a szén-monoxid deszorpciós görbe a réztartalomtól függetlenné válik $5 \mathrm{~m} / \mathrm{m} \%$-os $\mathrm{Cu}$ adalékolás felett, mivel állandóvá válik a rendelkezésre álló aktív helyek száma. Megállapították azt is, hogy a réz lerakódás egyrétegüből többrétegűvé változik, ezzel magyarázva az aktivitásbeli stagnálást magasabb réz tartalom esetén.

A metanol oxidatív karbonilezése során feltételezhető mechanizmust elméletileg vizsgálták Ren és munkatársai. A számítások szerint a DMC kialakulása során először monometilkarbonát (MMC) képződik metoxi-csoporthoz történő CO beékelődéssel, majd az MMC reagálva a metanollal DMC-ot alkot [74].

Hatféle DMC elöállítási módszert hasonlítottak össze gazdasági és környezetvédelmi mutatóik alapján, azzal a céllal, hogy megtalálják a leginkább fenntartható reakciót. A fenntarthatósági mutatók (elfogadott mérőszámok) alapján elkészített értékelés magában foglalja például a $\mathrm{CO}_{2}$ megkötési potenciálokat, a szennyezés-megelöző technológiák alkalmazhatóságát, az ipari megvalósíthatóságot. A gazdasági értékelésben a termék ára, a reagensek költsége (sztöchiometrikus mennyiségek alapján), míg a környezeti vizsgálatban a toxicitás és a környezeti hatás volt a fö szempont [75]. Az eredményeket az alábbi táblázatban foglaltuk össze [76]. 


\begin{tabular}{|c|c|c|c|}
\hline $\begin{array}{c}\text { Végső } \\
\text { besorolás }\end{array}$ & Előállítási mód & Pontszám & Korlátok \\
\hline 1 & $\begin{array}{c}\text { gőz fázisú metanol oxidatív } \\
\text { karbonilezése }\end{array}$ & 0,07 & nincs $\mathrm{CO}_{2}$ megkötés \\
\hline 2 & $\mathrm{CO}_{2}$ és metanol reakciója & 0,12 & $\begin{array}{c}\text { nem megvalósítható } \\
\text { iparilag }\end{array}$ \\
\hline 3 & metil-nitrit eljárás & 0,37 & nincs $\mathrm{CO}_{2}$ megkötés \\
\hline 4 & $\begin{array}{c}\text { etilén-oxid és a } \mathrm{CO}_{2} \\
\text { reakciója }\end{array}$ & 0,49 & 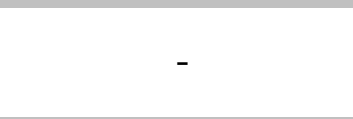 \\
\hline 5 & $\begin{array}{c}\text { karbamid és metanol } \\
\text { reakciója }\end{array}$ & 0,77 & - \\
\hline 6 & $\begin{array}{c}\text { metanol és foszgén } \\
\text { reakciója }\end{array}$ & 3,00 & - \\
\hline
\end{tabular}

1. táblázat DMC előállítás lehetőségek besorolása fenntarthatósági mutatók alapján, minél alacsonyabb az elért pontszám, annál zöldebb az elöállítási mód [75]

Az 1. táblázatban feltüntetettek szerint a gőz fázisú metanol oxidatív karbonilezése ugyan $\mathrm{CO}_{2}$ megkötéssel nem párosuló tevékenység, mégis gazdasági és környezetvédelmi szempontból a legelőnyösebb DMC elöállítási mód.

A dimetil-karbonát előállítását számos módszerrel és katalizátoron részletesen tanulmányozták változatos szelektivitást és a hozamot produkálva, azonban a DMC bomlást ritkán vették figyelembe.

$\mathrm{Az}$ irodalomban mégis található néhány eredmény a DMC bomlására vonatkozóan. Anderson és munkatársai összefoglalták a $\mathrm{Cu}$ zeoliton elért eredményeket témában. Kimutatták, hogy a katalizátor Brönsted savas centrumokkal rendelkezik, amelyek kialakulása a részleges réz ioncserének köszönhető. Ezeket piridinnel és $\mathrm{NH}_{3}$ adszorpcióval vagy kation $\left(\mathrm{Li}^{+}\right.$és $\left.\mathrm{Na}^{+}\right)$cserével módosították. A piridinnel kezelt $\mathrm{H}^{+} \mathrm{Y}$ zeolit csökkentette a DMC bomlást a rendelkezésre álló savas helyek számának csökkentésével. A trimetil-foszfit használata hasonló hatást gyakorolt a katalizátorra. A zeolit vizes fázisú $\mathrm{Li}^{+}$ion cseréjével próbálták csökkentetni a DMC bomlását a katalizátor savas helyeinek blokkolásával vagy eltávolításával [77].

A dimetoxi-metán (DMM) és a DMC termikus bomlását vizsgálták Fu és munkatársai $\mathrm{MgO}, \mathrm{H}-\mathrm{ZSM}-5, \mathrm{SiO}_{2}, \gamma-\mathrm{Al}_{2} \mathrm{O}_{3}$ és $\mathrm{ZnO}$ katalizátoron. A DMM $623 \mathrm{~K}$-ig stabil volt olyan bázikus jellegü oxidon, mint a $\mathrm{MgO}$ és csaknem teljes egészében elbomlott $423 \mathrm{~K}$-en a savas jellegü oxidon, mint a H-ZSM-5. A vizsgálatok azt mutatták, hogy a DMC könnyen 
elbomlik bázikus és savas jellegü oxidokon is, könnyen elbomlott MgO-on és H-ZSM-5 mintán. Még ennél is könnyebben ment végbe a bomlás amfoter $\gamma-\mathrm{Al}_{2} \mathrm{O}_{3}$-on. $\mathrm{A}$ bázikus és savas helyek párhuzamos jelenléte ugyanazon a felületen szinergikus hatást gyakorolt a DMC bomlásra. Mind a DMM mind a DMC viszonylag stabil volt $\mathrm{SiO}_{2}$-on és még stabilabb ZnO-on, feltételezhetően az alacsony felületi bázicitásuk és savasságuk miatt [78].

A DMC-ot elhanyagolható ökotoxicitása, alacsony bioakkumulációja, gyors lebomlása miatt környezetbarát vegyi anyagként tartják számon. Felhasználása kielégíti az egyre szigorodó környezeti elvárásokat. A DMC előállítása a foszgént használó folyamaton túllépve az utóbbi évtizedekben nagy fejlődésen ment keresztül, amelyből kiemeltem és összefoglaltam a leginkább fejlődőképeseket. Számos kutatás foglalkozik a leghatásosabb eljárás kidolgozásával. Mindehhez azonban elengedhetetlen a folyamatok során végbemenő lépések megismerése és feltérképezése. Nem elég tehát a legjobb katalizátor, az optimális hőmérséklet meghatározása, hanem alaposan kell vizsgálni a részfolyamatokat is. 


\section{Kísérleti rész}

\subsection{Katalizátorok előállítása}

Többfalú szén nanocsövet (MWCNT) acetilén katalitikus bontásával állítottuk elő 5\%-os $\mathrm{Co}, \mathrm{Fe} / \mathrm{Al}_{2} \mathrm{O}_{3}$ katalizátoron, álló ágyas, áramlásos reaktorban $993 \mathrm{~K}$-en. A termékeket a katalizátor részecskék feloldásával tisztítottuk $\mathrm{NaOH}$ majd tömény $\mathrm{HCl}$-oldat hozzáadásával [79].

Az aktív szén hordozós $\mathrm{Cu}, \mathrm{Cu}-\mathrm{Ni}$ és Ni katalizátorokat impregnálással állítottuk elö. A hordozót, Noritot (ROW 0,8 mm-es pellet, Alfa Aesar gyártmány) vagy MWCNT-t (az előbbiekben leírt eloállítás szerint) impregnáltuk ammónia oldatban feloldott $\mathrm{Cu}\left(\mathrm{NO}_{3}\right)_{2} * 3$ $\mathrm{H}_{2} \mathrm{O}$ és/vagy $\mathrm{Ni}\left(\mathrm{NO}_{3}\right)_{2} * 6 \mathrm{H}_{2} \mathrm{O}$ sókkal. A kétfémes minták esetében a $\mathrm{Cu} / \mathrm{Ni}$ atomarány 2 volt. Az elóállítás során számított mennyiségü fémsót feloldottunk 25\%-os ammónia oldatban, majd hozzáadtuk a hordozót $10 \mathrm{~m} / \mathrm{m} \%$-os fémtartalomig. Az elegyet 24 órán át kevertettük szobahömérsékleten, amit 2 órás ultrahangos kezelés követett. A mintát 24 órán keresztül öregítettük szobahőmérsékleten, majd 363 K-en vákuumbepárlással szárítottuk. A száraz port $\mathrm{N}_{2}$ áramban $723 \mathrm{~K}$-en kalcináltuk 3 órán át. A mintákat a reakciók előtt általában $873 \mathrm{~K}$-en hidrogén áramban 1 órán keresztül redukáltuk.

\subsubsection{Fajlagos felület mérése}

A katalizátorok BET felületét $\mathrm{N}_{2}$ adszorpcióval mértük folyékony nitrogén hőmérsékletén BELCAT A eszközzel, egypontos módszerrel.

A vizsgált katalizátorok BET felületei:

\begin{tabular}{ccccc}
\hline & \multicolumn{4}{c}{ BET felület $\left(\mathrm{m}^{2} / \mathrm{g}\right)$} \\
\hline Hordozó & Fémmentes & $\mathrm{Cu}$ & $\mathrm{Ni}$ & $\mathrm{Cu}-\mathrm{Ni}$ \\
MWCNT & 239 & 235 & 332 & 241 \\
Norit & 1212 & 1070 & 900 & 951 \\
\hline
\end{tabular}

2. táblázat Katalizátorok BET felülete 


\subsection{Módszerek}

\subsubsection{Katalitikus reakciók kivitelezése}

A katalitikus reakciót áramlásos rendszerben hajtottuk végre, álló ágyas kvarc reaktorban, légköri nyomáson. A reaktor cső belső átméröje $7 \mathrm{~mm}$, hossza körülbelül $20 \mathrm{~cm}$ volt. A katalizátorokat a reakciók előtt a fentiekben említettek szerint előkezeltük. Az adott mennyiségü katalizátort $873 \mathrm{~K}$-re felfütöttük $\mathrm{He}$ áramban, majd 60 percig $\mathrm{H}_{2}$ áramban redukáltuk. A rendszert He áramban visszahütöttük az adott reakcióhőmérsékletre.

A metanol oxidatív karbonilezése során $1 \mathrm{~g}$ katalizátort előkezeltünk. A reakciót általában $393 \mathrm{~K}$-en követtük. A metanolt a rendszerbe gázmosón keresztül vittük be, a $\mathrm{CO}$ és $\mathrm{O}_{2}$ keverék átbuborékoltatásával, $323 \mathrm{~K}$ hőmérsékletü metanolon keresztül. A reagensek aránya $\left(\mathrm{CH}_{3} \mathrm{OH} / \mathrm{CO} / \mathrm{O}_{2}=2 / 1 / 1\right)$ azonos volt a kísérletek során. Az együttes áramlási sebesség $16 \mathrm{ml} / \mathrm{min}$ volt.

A DMC bontás során $0,3 \mathrm{~g}$ katalizátort a fent említett módon elökezeltünk. A DMC-ot gázmosón keresztül vezettük a rendszerbe, amely során szobahőmérsékletü DMC-on He vivőgázt buborékoltattunk keresztül $(\mathrm{DMC} / \mathrm{He}=1 / 4)$. Az együttes áramlási sebesség 16 $\mathrm{ml} / \mathrm{min}$ volt a kísérletek során. Végeztünk hömérséklet programozott, valamit izoterm méréseket is. A redukálás után az első esetben He áramban szobahőmérsékletre hütöttük vissza a katalizátort és a reakció indítása után $5 \mathrm{~K} / \mathrm{min}$ sebességgel fütöttük általában 873K-ig. A második esetben a reakció hőmérséklete általában $473 \mathrm{~K}$ volt.

A reagenseket és a termékeket on-line analizáltuk Agilent 6890 típusú gázkromatográffal (GC), az elválasztáshoz HP PlotQ típusú kolonnát használtunk. A GC Agilent MSD 5975C VL típusú tömegspektrométerrel (MS), hővezetőképességi (TC) és láng ionizációs (FI) detektorokkal volt ellátva. A szén-monoxid és a szén-dioxid jobb kimutathatósága érdekében a müszer egy metanizáló egységet is tartalmazott, ami az előbb említett anyagokat $\mathrm{H}_{2}$ áramban Ni katalizátor segítségével a FI detektorban nagy érzékenységgel detektálhatóvá alakította át. A gázkromatográf vezérlését és a kromatogramok kiértékelését ChemStation nevü szoftverrel végeztük.

A kromatogramokból nyert anyagmennyiségi adatok segítségével számítottuk a termékek szelektivitását az alábbi képlet szerint: 


$$
S_{i}=\frac{x_{i} n_{i}}{\sum_{i} x_{i} n_{i}} * 100
$$

ahol $x_{i}$ az adott termék (i) móltörtje, $n_{i}$ pedig a szénatomok száma az adott termék molekulájában.

A metanol/CO/DMC konverziót az alábbi képlettel definiáltuk:

$$
K=\frac{\sum_{i} x_{i} n_{i}}{x_{0}+\sum_{i} x_{i} n_{i}} * 100
$$

ahol $\mathrm{x}_{\mathrm{i}}$ az adott reagens móltörtje, $\mathrm{n}_{\mathrm{i}}$ az adott termék szénatomjainak száma a metanol/CO/DMC szénatom számához viszonyítva, $\mathrm{x}_{0}$ pedig az el nem reagált metanol/CO/DMC móltörtje.

A konverziókat és a termékek szelektivitását a kromatogramokból nyert anyagmennyiségekből Microsoft Excel segítéségével számoltuk ki, majd az Origin szoftverrel ábrázoltuk.

\subsubsection{Röntgen fotoelektron spektroszkópiás vizsgálatok (XPS)}

Az XPS mérésekhez a mintákat körülbelül $10 \mathrm{~mm}$ átméröjü, néhány tized mm-es vastagságú tablettákká préseltük majd a spektrométer zsiliprendszerébe helyeztük. A minták kezelését úgynevezett nagynyomású cellában (katalízis kamra) végeztük, amely közvetlenül kapcsolódik egy záró szeleppel izolálható analizáló kamrához. A minta egy manipulátor és egy másodlagos mozgató mechanizmus segítségével átemelhető az analizáló kamrából a nagynyomású cellába vákuum alatt anélkül, hogy közben levegővel érintkezne. A minták előkezelése megegyezett a katalitikus reakció kivitelezésénél leírtakkal. Minden elökezelési lépés után a mintát nitrogén áramban lehütöttük szobahőmérsékletre. Ezután az áramlást megállítottuk, a nagynyomású cellát leszívattuk, és a mintát visszavittük az analizáló kamrába. Az XP spektrumokat egy PHOIBOS 150 MCD 9 félgömb energia analizátorral ellátott SPECS müszerrel rögzítettük, amely FAT módban üzemelt. A gerjesztő forrás a magnéziumanód $\mathrm{K}_{\alpha}$ sugárzása $(\mathrm{h} v=1253,6 \mathrm{eV})$ volt. A röntgen ágyú $210 \mathrm{~W}$ teljesítménnyel $(14 \mathrm{kV}, 15 \mathrm{~mA})$ müködött. A pass energy $20 \mathrm{eV}$ volt, az energia lépésköz pedig $25 \mathrm{meV}$. Általában öt söpretést összegeztünk egy spektrum 
elkészítéséhez. Az adatok feldolgozásához és értékeléséhez mind gyártói (Specslab2) mind kereskedelmi (CasaXPS, Origin) szoftvercsomagot használtunk.

\subsubsection{Infravörös spektroszkópiás vizsgálatok (IR)}

A katalitikus reakció közben a felületen kialakuló formák analíziséhez infravörös spektrumokat rögzítettünk egy diffúz reflexiós cellával (Harrick) felszerelt $\mathrm{BaF}_{2}$ ablakú \pm 4 $\mathrm{cm}^{-1}$ hullámszám felbontású Agilent Cary 670 típusú FTIR spektrométerrel. Jellemzően 32 felvételt összegeztünk. Az egész optikai útvonalat $\mathrm{N}_{2}$-nel öblítettük. A katalizátorokat a fent leírt módon előkezeltük, majd a katalitikus mérések kísérleti körülményeit alkalmaztuk és az infravörös spektrumokat rögzítettük. Az eredmények kiértékelésénél jellemzően az előkezelt katalizátoron rögzített spektrumot használtuk háttérként. A spektrumok kiértékelését Agilent Resolutions Pro 5.2.0 szoftverrel végeztük.

\subsubsection{DMC hömérséklet programozott deszorpciós vizsgálatok (TPD)}

A reagensek adszorpcióját és a deszorbeált termékeket mikromérleg (Netzsch STA 409 PC) segítségével mértük és a hozzá kapcsolt tömegspektrométer (Pfeiffer QMS 200) segítségével elemeztük. Az előkezelés után a katalizátort tartalmazó kamrát He-mal öblítettük át és közben szobahőmérsékletre hütöttük. A DMC-ot úgy adszorbeáltattuk a felületre, hogy a He vivőgázt $40 \mathrm{ml} / \mathrm{min}$ sebességgel 30 percig $273 \mathrm{~K}$ hőmérsékletü DMCon buborékoltattuk át és vezettük a katalizátorágyra. Ezt követően a kamrát ismét átöblítettük tiszta héliummal 15 percen keresztül. A felületen megkötődött $\mathrm{DMC}$ mennyiségére a katalizátor súlyváltozásából következtettünk. A mintánkat ezután 20 $\mathrm{K} /$ min sebességgel $40 \mathrm{ml} / \mathrm{min}$ He áramban szobahőmérsékletről $900 \mathrm{~K}$-ig fütöttük, és a deszorbeálódó termékeket tömegspektrométerrel követtük.

\subsection{5 $\mathrm{NH}_{3}$ és $\mathrm{CO}_{2}$ hömérséklet programozott deszorpciós vizsgálatok (TPD)}

A katalizátorokon végzett $\mathrm{NH}_{3}$ és $\mathrm{CO}_{2}$ TPD vizsgálatokat TC detektorral ellátott BELCAT A készülékkel végeztük. A reaktort (amely $100 \mathrm{mg}$ katalizátort tartalmazott) elöször 873 $\mathrm{K}$-en 60 percig redukáltuk $\mathrm{H}_{2}$ áramban, majd He áramban lehütöttük $373 \mathrm{~K}$-re. Ezután $\mathrm{NH}_{3}$ vagy $\mathrm{CO}_{2}$ áramot $(50 \mathrm{ml} / \mathrm{min})$ vezetünk a reaktorba 30 percen keresztül, majd 15 percig öblítettük He-mal. Végül a rendszert $(20 \mathrm{~K} / \mathrm{min}$ fütési sebességgel) He-ban $873 \mathrm{~K}$-ig fütöttük. 


\section{Célkitüzés}

A zöld kémia a környezetbarát anyagok tanulmányozását és előállítását tartja szem elött, olyan fenntartható lehetőségeket vizsgálva, amelyek kísérleti és ipari szinten is kivitelezhetőek.

A dimetil-karbonát olyan környezetbarát anyag, amely sokoldalúan felhasználható, azonban előállítási módszerei a zöld kémia elvárásainak nem megfelelőek.

Munkám célja a dimetil-karbonát környezetbarát katalitikus szintézisének fejlesztése. A kísérletek kivitelezése során alacsony környezeti hatású reagensek használata és káros melléktermékek keletkezésének minimalizálása fó szempont volt. A dimetil-karbonát előállítási lehetőségei közül a metanol oxidatív karbonilezési reakciójának részletes tanulmányozásával foglalkoztam, amelyet egy áramlásos rendszerben, álló ágyas reaktorban, atmoszferikus nyomáson vizsgáltam. Az irodalomban gyakran említett klorid tartalmú katalizátorok használatát mindenképp mellözni kívántam.

A reakció komplexitása miatt több párhuzamos kísérlet sorozatot hajtottunk végre. A katalizátorok és a felületi folyamatok jellemzésére röntgen fotoelektron spektroszkópiás, infravörös spektroszkópiás valamint hőmérséklet programozott deszorpciós vizsgálatokat alkalmaztunk.

Célom, hogy a szintézis a kivitelezés körülményei, a felhasznált anyagok valamint a reakciók során keletkező mellék- és végtermékek tekintetében is környezetbarátnak minősüljön. 


\section{Eredmények és kiértékelésük}

A metanol oxidatív karbonilezését az összehasonlíthatóság érdekében többfajta $\mathrm{Cu}, \mathrm{Cu}-\mathrm{Ni}$ és Ni katalizátoron tanulmányoztuk azonos reakciókörülmények között. A minták közül az MWCNT és a Norit (aktív szén) hordozós Cu katalizátorok aktivitása kiemelkedő volt, így ezeket részletesen vizsgáltuk.

\subsection{Többfalú szén nanocső hordozós katalizátorok vizsgálata}

\subsubsection{Metanol oxidativ karbonilezése}

A katalitikus reakciót légköri nyomáson, $393 \mathrm{~K}$-en $\mathrm{Cu}$, Ni és $\mathrm{Cu}-\mathrm{Ni} / \mathrm{MWCNT}$ katalizátoron végeztük. Összehasonlításképpen többféle katalizátor alkalmasságát teszteltük. A reakciók során $\mathrm{CO}_{2}$, DMC és $\mathrm{MF}$ volt a fötermék. $\mathrm{Cu} / \mathrm{MWCNT}$ esetében DME és DMM is képződött kis mennyiségben.

$\mathrm{Cu} / \mathrm{MWCNT}(\mathrm{A})$

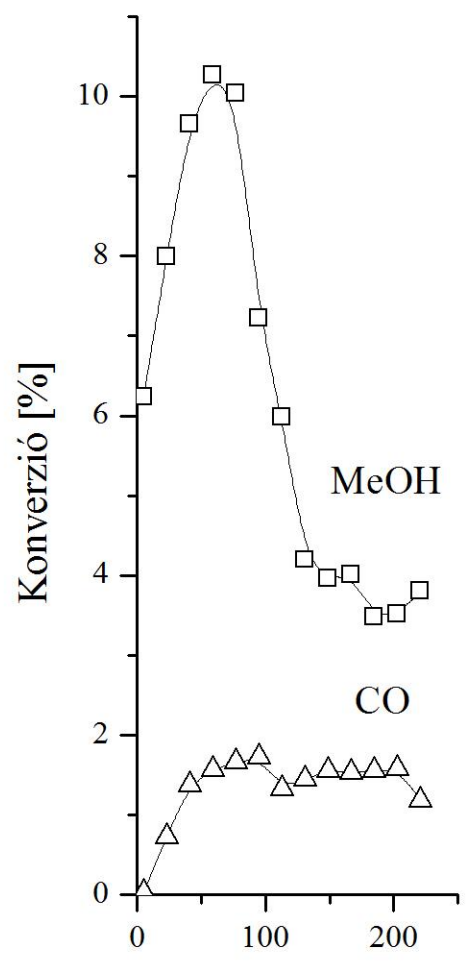

Idő [min]
$\mathrm{Ni} / \mathrm{MWCNT}(\mathrm{B})$

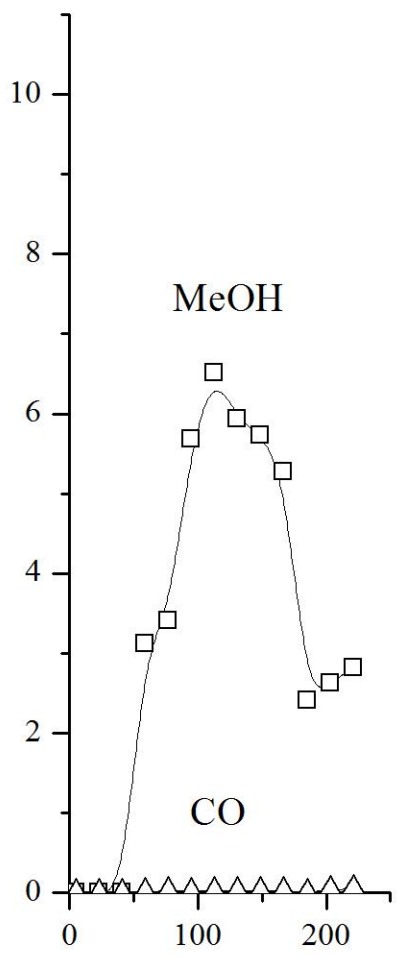

Idő [min]
$\mathrm{Cu}-\mathrm{Ni} / \mathrm{MWCNT}(\mathrm{C})$

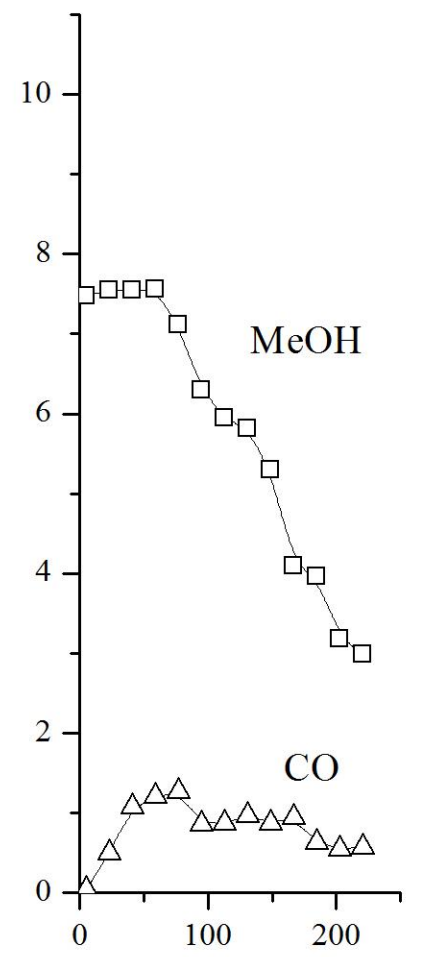

Idő [min]

1. ábra $\mathrm{CO}$ és metanol konverziója $\mathrm{Cu}(\mathrm{A}), \mathrm{Ni}(\mathrm{B})$ és $\mathrm{Cu}-\mathrm{Ni} / \mathrm{MWCNT}$ (C) katalizátorokon $\mathrm{CH}_{3} \mathrm{OH}+\mathrm{CO}+\mathrm{O}_{2}$

\section{(2:1:1) reakció során $393 \mathrm{~K}$-en}

A metanol konverzió $\mathrm{Cu} / \mathrm{MWCNT}$ mintán 10\%-ig nőtt a reakció első 60 percében, majd a maximum elérése után fokozatosan csökkent, a közel állandó aktivitású szakaszban beállt 
értéke körülbelül $4 \%$ volt 2 óra eltelte után. Ugyanezen reakcióban a CO konverzió nőtt a reakció első órájában, majd 60 perc után közel állandó maradt, körülbelül 1,5\% volt.

A metanol konverzió Ni/MWCNT katalizátoron végrehajtott kísérletek esetében a reakció századik percéig növekedett és 6,5\% körül elérte a maximumot, majd drasztikusan csökkent. A CO konverzió érdekes eredményt mutatott, értéke nem változott, a reakció során végig nulla maradt.

A metanol konverzió Cu-Ni/MWCNT katalizátoron 7,5\% körüli volt a reakció elején, de egy óra elteltével folyamatosan csökkent és még 220 perc után sem érte el az állandó aktivitású szakaszt 3\% alatt. A CO konverzió hasonló tendenciát mutatott, mint a $\mathrm{Cu} / \mathrm{MWCNT}$ katalizátor esetében, nőtt a reakció első órájában, majd közel állandó maradt, $1 \%$ körül (1. ábra).
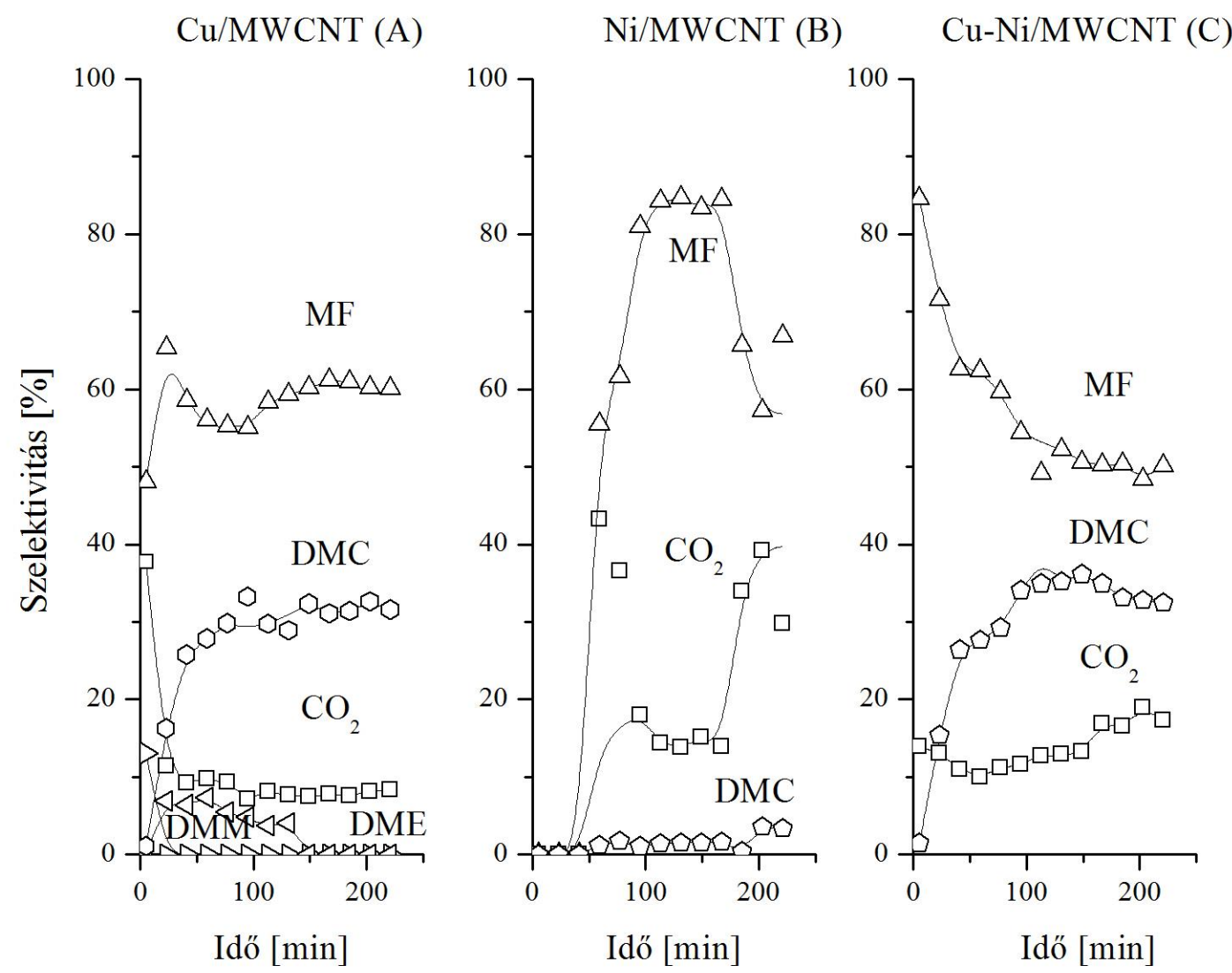
A MF szelektivitása kissé, a DMC szelektivitása szignifikánsan növekedett a reakció elején a $\mathrm{Cu} / \mathrm{MWCNT}$ esetében. 60 perc elteltével a MF szelektivitása körülbelül $55 \%$ volt, a DMC pedig 30\% körüli. A $\mathrm{CO}_{2}$ szelektivitás 38\%-ról kevesebb, mint $10 \%$-ra csökkent a reakció elörehaladtával. DMM csak a kezdeti szakaszban, DME pedig a reakció első százötven percében keletkezett kis mennyiségben.

A Ni/MWCNT katalizátor esetében a MF szelektivitása az első 50 perc után ugrásszerüen növekedett 85\%-ig, majd száz perc után csökkenni kezdett. A $\mathrm{CO}_{2}$ szelektivitása 40\%-ig növekedett, azonban a DMC szelektivitása csak 2,2\%-os maximumot ért el a kétszázhuszadik perc után.

A Cu-Ni/MWCNT katalizátor alkalmazása során a MF szelektivitása 85\%-ról csökkent 50\%-ra, a DMC fokozatosan 35\%-ra valamint a $\mathrm{CO}_{2}$ 17\%-ról 22\%-ra nőtt az idő előrehaladtával (2. ábra).

$\mathrm{Cu} / \mathrm{MWCNT}(\mathrm{A})$

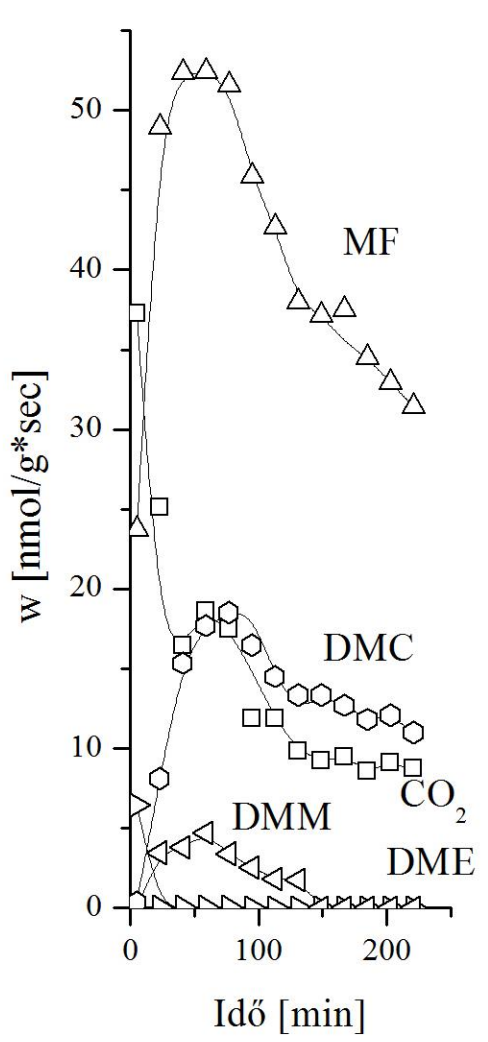

Idő [min]
Ni/MWCNT (B)

$\mathrm{Cu}-\mathrm{Ni} / \mathrm{MWCNT}$ (C)
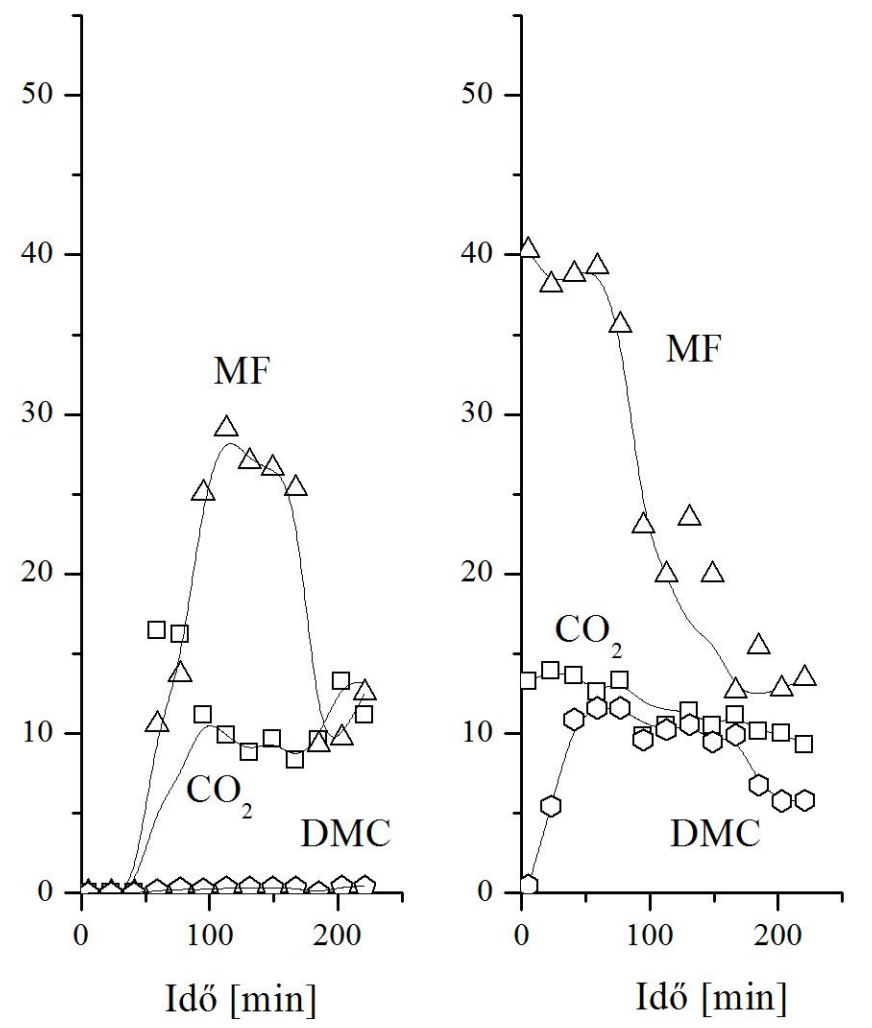

3. ábra DMC, MF, $\mathrm{CO}_{2}$, DMM és DME képződési sebességei $\mathrm{Cu}$ (A), Ni (B) és Cu-Ni/MWCNT (C) katalizátorokon $\mathrm{CH}_{3} \mathrm{OH}+\mathrm{CO}+\mathrm{O}_{2}(2: 1: 1)$ reakció során 393 K-en 
A Cu/MWCNT esetében a MF, a $\mathrm{CO}_{2}$ és a DMM képződési sebességek maximum görbe szerint változtak időben $\left(\mathrm{w}_{\operatorname{maxMF}}=53 \mathrm{nmol} / \mathrm{g} * \mathrm{sec}, \mathrm{w}_{\operatorname{maxCO} 2}=17 \mathrm{nmol} / \mathrm{g}^{*} \mathrm{sec}\right.$ és $\mathrm{w}_{\operatorname{maxDMM}}=$ $17 \mathrm{nmol} / \mathrm{g} * \mathrm{sec})$. A DMC képződési sebessége szignifikánsan, a DME-é pedig enyhén csökkent.

A Ni/MWCNT katalizátor esetében a MF és a $\mathrm{CO}_{2}$ képződési sebessége az idő előrehaladtával növekedett, azonban a MF 180 perc után csökkenni kezdett. A DMC képződési sebessége igen alacsony maradt végig a reakció folyamán.

A Cu-Ni/MWCNT mintán a MF képződési sebessége jelentősen, 40-ről 14 nmol/g*sec-ra, amíg a $\mathrm{CO}_{2}$ enyhén, 13-ról $10 \mathrm{nmol} / \mathrm{g}$ *sec-ra csökkent a reakció alatt, miközben a DMC $\left(\mathrm{w}_{\text {maxDMC }}=12 \mathrm{nmol} / \mathrm{g}^{*} \mathrm{sec}\right)$ képződési sebessége maximum görbe szerint változott $(3$. ábra).

A DMC képződési sebessége közel kétszerese volt $\mathrm{Cu}$ /MWCNT katalizátoron, mint a CuNi/MWCNT mintán, bár a szelektivitás valamivel magasabb volt a második esetben. A Ni/MWCNT katalizátoron csak kis mennyiségben keletkezett DMC.

Bian és munkatársai [28] megállapították, hogy az MWCNT hordozós Cu-Ni kétfémes katalizátorok aktívak DMC direkt szintézisben $\left(\mathrm{CH}_{3} \mathrm{OH}+\mathrm{CO}_{2}\right.$ reakcióban) 393 K-en . Tapasztalataik szerint a DMC hozam 0,4 MPa nyomáson és $393 \mathrm{~K}$ 0,9\% volt, ami a nyomás csökkentésével együtt csökkent. Az általunk végzett kísérletek során a DMC hozam körülbelül 2,1\% volt $\mathrm{Cu}-\mathrm{Ni} / \mathrm{MWCNT}$ mintán légköri nyomáson a reakció elején. Ez az érték folyamatosan csökkent a reakció idővel ugyanúgy, mint a metanol konverziója. A reakció 240. percében, a DMC hozam már csak 0,99\% volt. Cu/MWCNT esetében a közel állandó aktivitású szakaszban a DMC kitermelés körülbelül 1,2\% volt. Az általunk bemutatott értékek atmoszferikus nyomáson is magasabbak, mint a közölt irodalmi adatok DMC szintézis során 0,4 MPa nyomáson Cu-Ni/MWCNT katalizátoron [28]. 


\subsubsection{Metanol oxidációja}

A
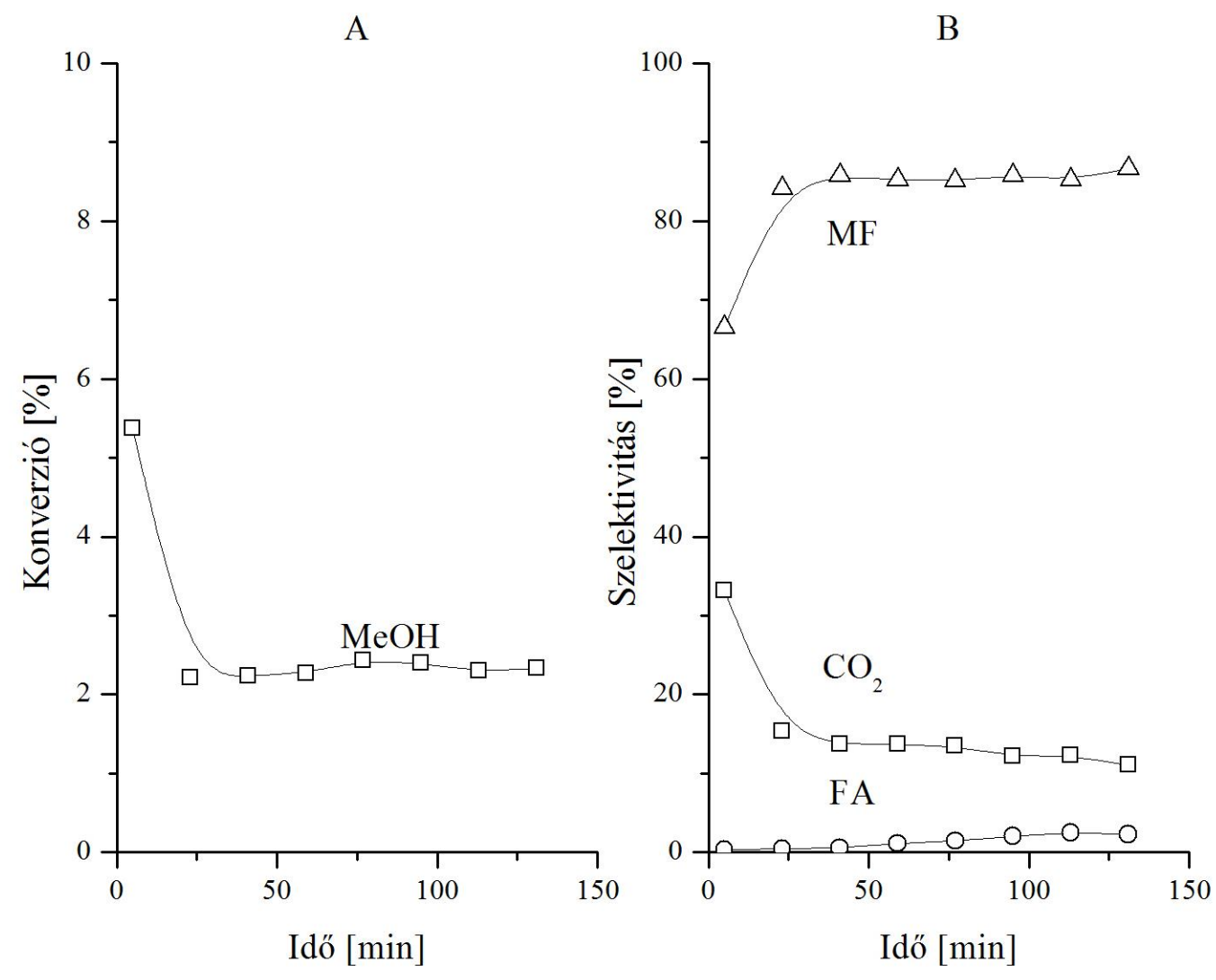

4. ábra Metanol konverziója (A) valamint $\mathrm{MF}, \mathrm{CO}_{2}$, és FA szelektivitásai (B) $\mathrm{Cu} / \mathrm{MWCNT}$ katalizátoron

$\mathrm{CH}_{3} \mathrm{OH}+\mathrm{O}_{2}(2: 1)$ reakció során $393 \mathrm{~K}$-en

A metanol oxidatív karbonilezése során keletkezett termékek képződési mechanizmusának jobb megértése érdekében vizsgáltuk azonos kinetikai paraméterek között a metanol oxidációját is a korábban használt katalizátorokon.

A metanol konverziókban nem volt szignifikáns különbség a különböző katalizátorok használata során. Ezekben az esetekben MF volt a fő termék valamint kis mennyiségü $\mathrm{CO}_{2}$ és nyomokban formaldehid (FA) is képződött, mint például a $\mathrm{Cu} /$ Norit katalizátor esetében, mint ahogy azt a 4. ábra mutatja. A képződési sebességek az első harminc percben csökkentek, majd stabilizálódtak. 


\subsubsection{DMC katalitikus bontása}

Külön kísérletben vizsgáltuk a DMC szintézisben az MWCNT hordozós minták közül a legaktívabb katalizátoron a DMC bomlását. Összehasonlításként bemutatjuk a hordozó, az MWCNT hatását is.

MWCNT

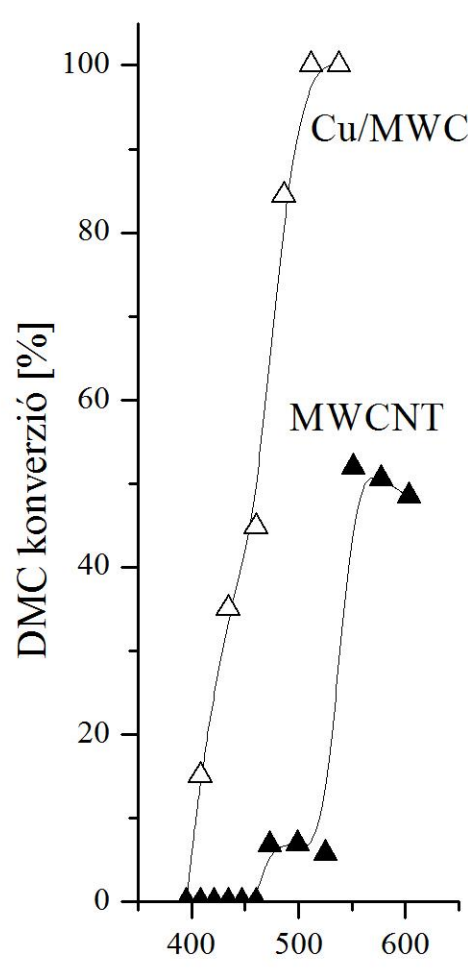

Hőmérséklet [K]

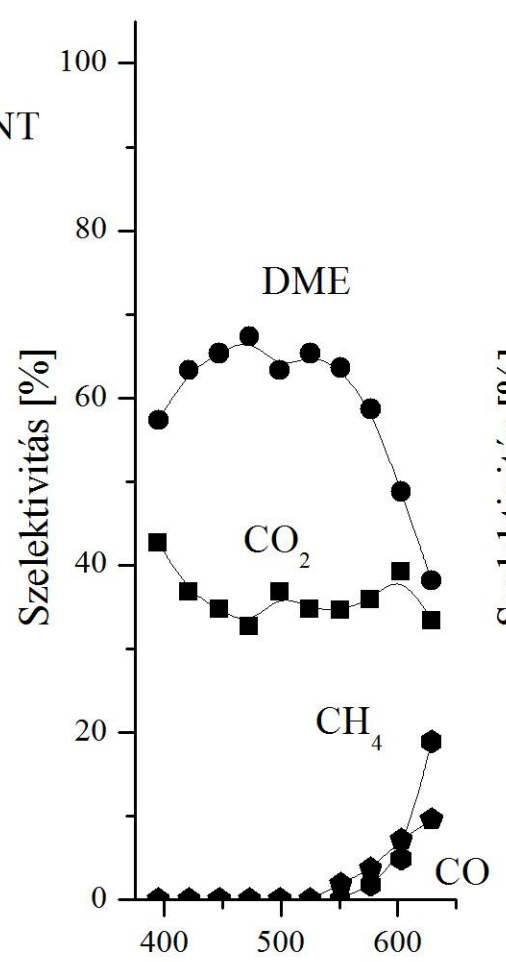

Hőmérséklet [K]
$\mathrm{Cu} / \mathrm{MWCNT}$

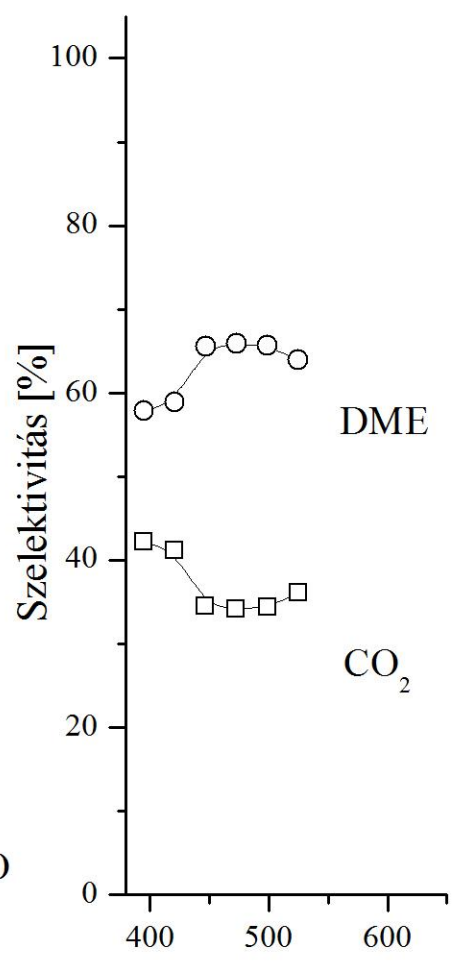

Hömérséklet [K]

5. ábra DMC konverziója (A) MWCNT és Cu/MWCNT mintákon a keletkezett termékek szelektivitásainak változása MWCNT (B) és Cu/MWCNT mintákon (C) DMC bontás során a hőmérséklet függvényében

$\mathrm{Az}$ 5. ábra a DMC konverzióját és a termékek szelektivitását mutatja $\mathrm{Cu} / \mathrm{MWCNT}$ minta esetében a hőmérséklet programozott reakcióban, amely során $\mathrm{CO}, \mathrm{CH}_{4}, \mathrm{CO}_{2}, \mathrm{DME}$ és $\mathrm{CH}_{3} \mathrm{OH}$ volt a fö termék. A DMC bomlás $430 \mathrm{~K}$ fölött indult meg a $\mathrm{Cu} / \mathrm{MWCNT}$ mintán, és körülbelül 550 K-nél érte el a 100\%-os DMC konverziót. A tiszta MWCNT aktivitása sokkal gyengébb volt, hasonló mértékü átalakulást mintegy 100 K-nel magasabb hőmérsékleten kaptunk. A konverzió ebben az esetben csak 530 K-ig emelkedett (36\% volt), ezután csökkenni kezdett.

Alacsonyabb hömérséklettartományban minden esetben $\mathrm{DME}$ és $\mathrm{CO}_{2}$ képződött. Magasabb hőmérsékleten a hordozón a DME szelektivitás csökkent, a $\mathrm{CO}$ és a $\mathrm{CH}_{4}$ 
szelektivitás nőtt a hőmérséklet függvényében. A termékek szelektivitása a hordozón és a $\mathrm{Cu} / \mathrm{MWCNT}$ mintán körülbelül megegyezett.

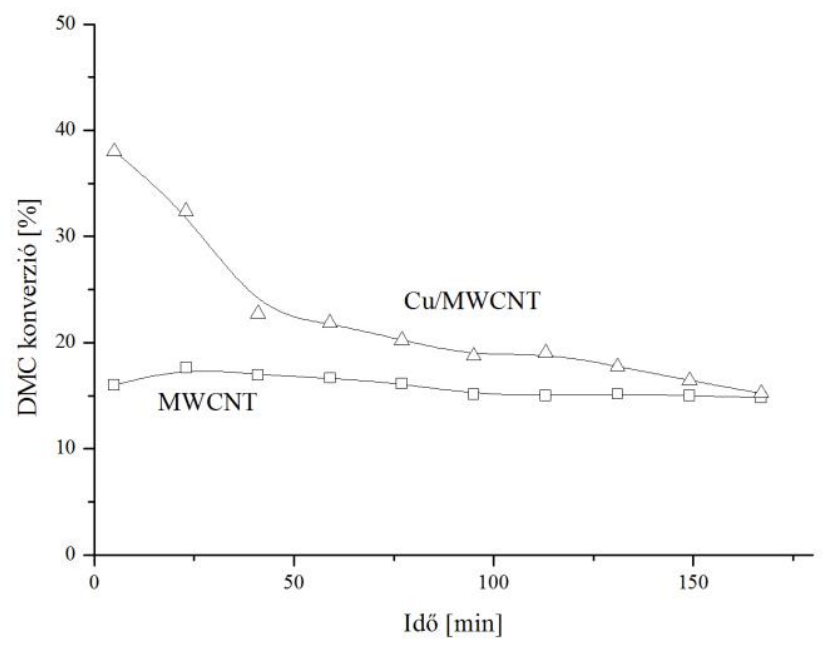

6. ábra DMC konverziója MWCNT és Cu/MWCNT mintákon izoterm DMC bontás során $473 \mathrm{~K}$-en

A DMC bontását részleteiben tanulmányoztuk izoterm körülmények között $\mathrm{Cu} / \mathrm{MWCNT}$ katalizátoron és tiszta hordozón $473 \mathrm{~K}$-en (6. ábra). A DMC konverzió $\mathrm{Cu} / \mathrm{MWCNT}$ mintán jelentősen csökkent az idő függvényében a reakció első órájában, amíg a tiszta hordozón viszonylag stabil volt. A termékek DME és $\mathrm{CO}_{2}$ voltak mindkét esetben és a szelektivitásuk is hasonlóan alakultak.

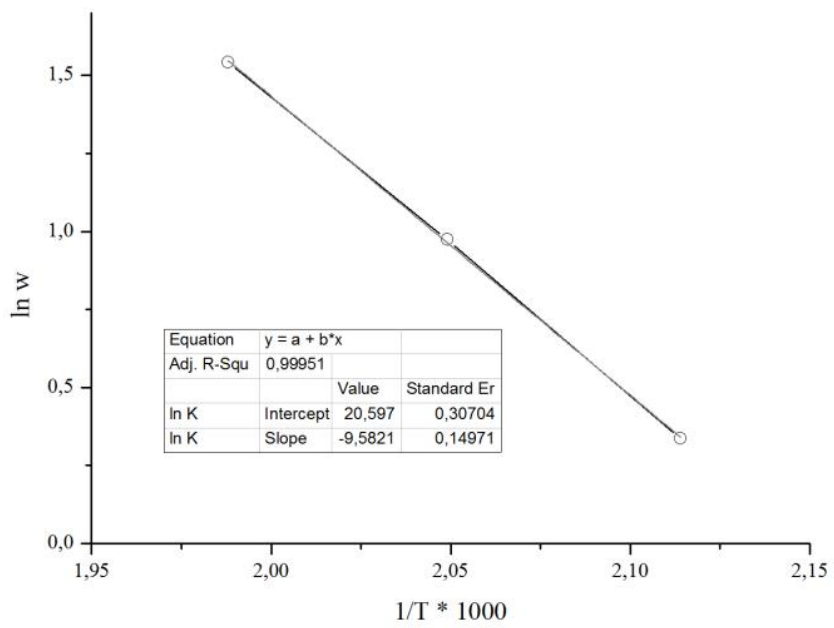

7. ábra DMC bomlás során a DMC fogyás sebességének hőmérsékletfüggése $\mathrm{Cu} / \mathrm{MWCNT}$ katalizátoron 
Amikor a reakciót magasabb hőmérsékleten hajtottuk végre (488 és $503 \mathrm{~K}$ ) a konverziók nőttek valamint a $\mathrm{Cu} / \mathrm{MWCNT}$ mintán $485 \mathrm{~K}$ felett kis mennyiségü $\mathrm{CO}$ és $\mathrm{CH}_{4}$ is képződött.

A DMC fogyás sebességének hőmérsékletfüggéséből meghatároztuk a bomlás aktiválási energiáját (7. ábra) az Arrhenius egyenlet alapján, amelyre 79,6kJ/mol értéket kaptunk. Ezeket az adatokat figyelembe véve a metanol oxidatív karbonilezésénél használt $393 \mathrm{~K}$ reakció hőmérsékletre extrapoláltuk. Kiszámoltuk a DMC szintézis során lezajlódó DMC bomlás konverzióját (0,036\%), amelyböl arra következethetünk, hogy a szintézis során a bomlás mértéke nem számottevő.

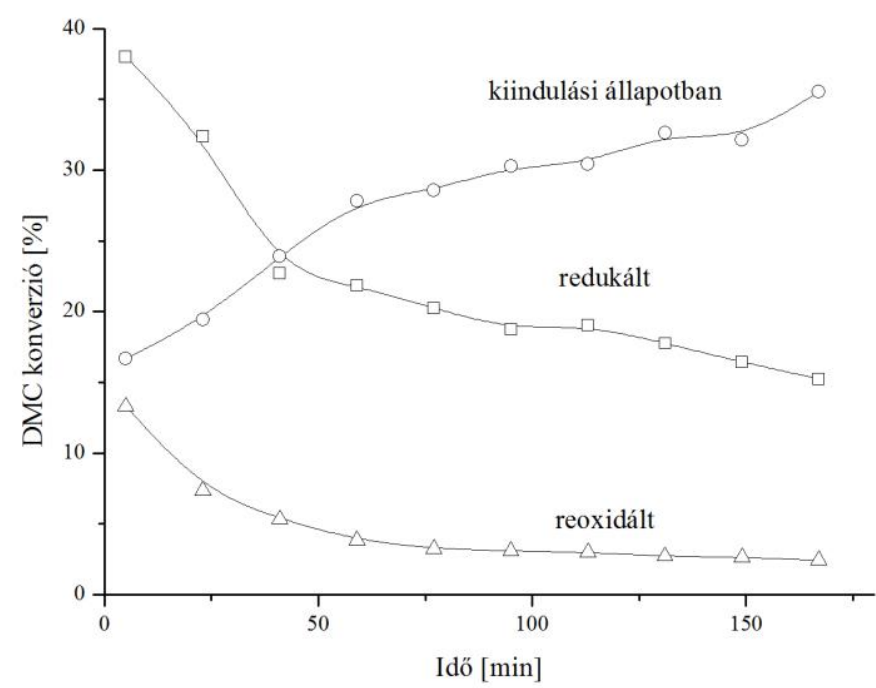

A katalizátor előkezelése változó hatást gyakorolt a DMC bomlására $473 \mathrm{~K}$-en (8. ábra). A redukált $\mathrm{Cu}$ /MWCNT mintán a DMC konverzió a kezdeti 37\%-ról lecsökkent 16\%-ra 150 perc alatt, mint ahogy a 8. ábra mutatja. Amikor nem alkalmaztunk előzetes redukciót (kiindulási állapotban) a DMC konverzió 17\%-ról 35\%-ra növekedett. Amennyiben a redukált katalizátort újra oxidáltuk, a DMC konverzió sokkal alacsonyabb volt, mint amikor csak redukáltuk a mintát, habár időben szintén csökkent, a közel állandó aktivitású szakaszban is csak körülbelül $3 \%$ volt. 


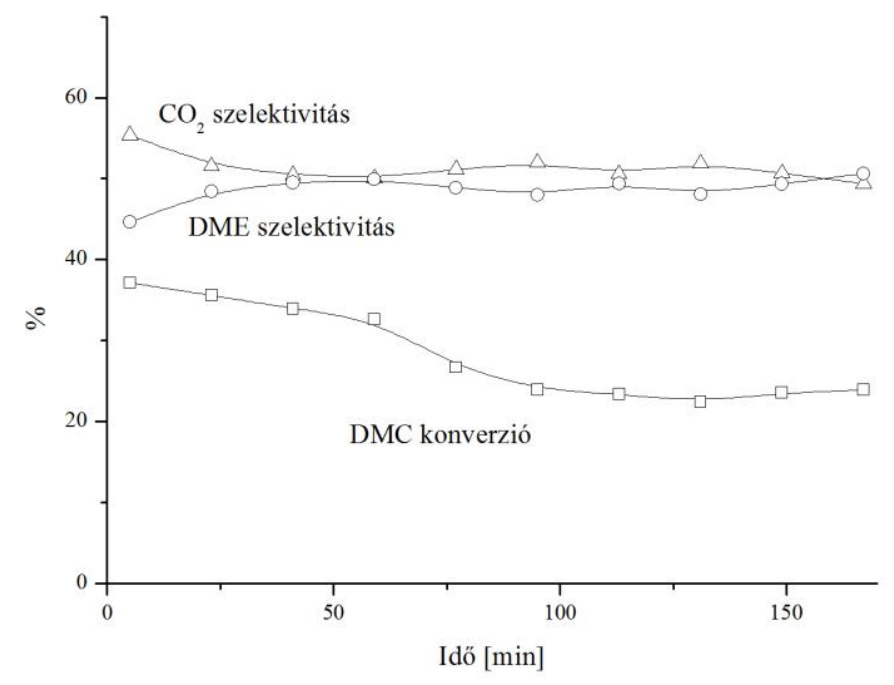

9. ábra DMC konverziója valamint DME és $\mathrm{CO}_{2}$ szelektivitása $\mathrm{Cu} / \mathrm{MWCNT}$ katalizátoron izoterm DMC + $\mathrm{O}_{2}$ reakció során $473 \mathrm{~K}$-en

Amikor $\mathrm{O}_{2}$ - $\mathrm{t}\left(\mathrm{DMC} / \mathrm{O}_{2} / \mathrm{He}=1 / 2 / 2\right)$ is kevertünk a reakcióelegyhez, a DMC konverzió 473 $\mathrm{K}$-en $\mathrm{Cu} / \mathrm{MWCNT}$ mintán hasonlóan alakult, mint a redukált minta esetében, jóllehet 80 perc elteltével a konverzió elért egy állandó értékét, amely körülbelül $22 \%$ volt. A $\mathrm{Cu} / \mathrm{MWCNT}$ mintán oxigén jelenlétében is $\mathrm{DME}$ és $\mathrm{CO}_{2}$ képződött (9. ábra).

Azért, hogy kizárjuk annak lehetőségét, hogy a DMC bomlás első lépésében metanol keletkezik, amely tovább reagálva DME-t képez, a metanol bomlását is tanulmányoztuk 473 K-en Cu/MWCNT katalizátoron. A kísérlet során sem metanol fogyást, sem termékképződét nem tapasztaltunk. A metanol az adott körülmények között nem bomlott el, így joggal feltételezhetjük, hogy a DME, amit a DMC bontás során kimutattunk, közvetlenül a reakció során keletkezett.

\subsubsection{XP spektroszkópiás vizsgálatok}

A katalizátorok felületi jellemzése céljából XPS vizsgálatokat is végeztünk. A reakció kinetikai paraméterei megegyeztek a korábbiakban alkalmazottakkal. 


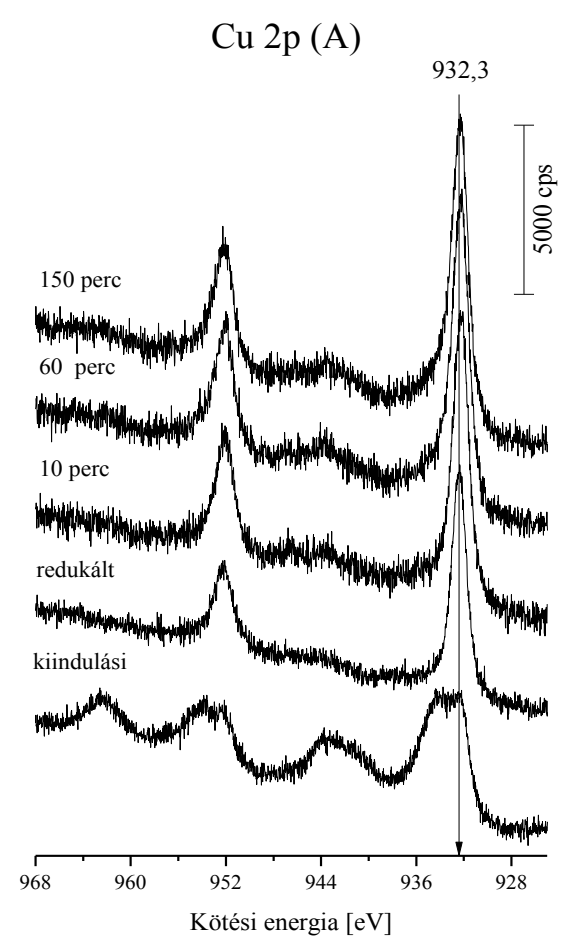

$\mathrm{Cu} \operatorname{LMM}(\mathrm{B})$

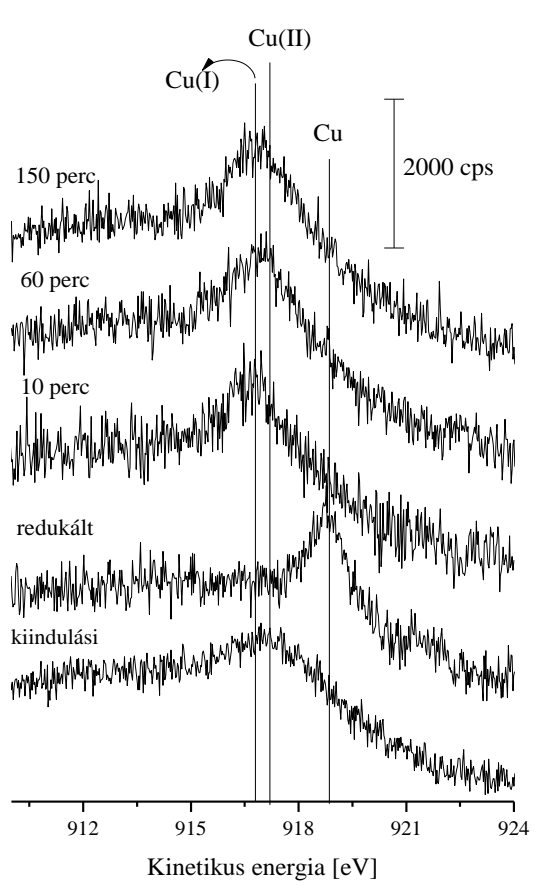

10. ábra Cu 2p XP spektrumok (A) és Cu LMM Auger spektrumok (B) Cu/MWCNT katalizátoron kiindulási és redukált állapotban, a $\mathrm{CH}_{3} \mathrm{OH}+\mathrm{CO}+\mathrm{O}_{2}(2: 1: 1)$ reakció 10., 60., 150. percében $393 \mathrm{~K}$-en

Nagy felbontású XP spektrumokat rögzítettünk Cu/MWCNT katalizátor esetében a Cu 2p, $\mathrm{Ni} 2 \mathrm{p}, \mathrm{C} 1 \mathrm{~s}, \mathrm{O} 1 \mathrm{~s}$ és $\mathrm{Cu} \mathrm{LMM}$ régiókban a kezelés és a reakció minden szakaszában. A Cu $2 \mathrm{p}_{3 / 2}$ csúcs pozíciója a kezeletlen mintán (kiindulási) $\mathrm{Cu}\left(\mathrm{NO}_{3}\right)_{2}$ jelenlétét mutatta 935,5 eV-nál [80] valamint CuO-ot 932,3 eV-nál, ami a nitrát só bomlásából származhat. Az utóbbi csúcs elhelyezkedése nem változott a redukció után, de a szatellitek eltüntek, ami a réz redukciójára utal (10. ábra) [81]. A fémben és a $\mathrm{Cu}^{+}$állapotban a kötési energia nagyon hasonló, ezért megkülönböztetésükhöz figyelembe kell venni az Auger paramétert is, amely egyszerüsített formában a $\mathrm{Cu} 2 \mathrm{p}_{3 / 2}$ kötési energiának és az $\mathrm{L}_{3} \mathrm{MM}$ átmenet kinetikai energiájának összege. Ezek alapján a réz fémmé redukálódott az előkezelés során. A reakció alatt a $\mathrm{Cu} 2 \mathrm{p}_{3 / 2}$ kötési energia és a jelintenzitás nem változott, de megjelent egy új szatellit csúcs 944 eV körül. Ez a csúcs megfigyelhető volt még a reakció tízedik perce után is. Az Auger spektrumok jobban hasonlítanak a kiindulási állapothoz, mint a redukció után rögzített spektrumhoz. Tehát arra következtethetünk, hogy a réz oxidálódott a reakcióelegyben, és leginkább a $\mathrm{Cu}^{+}$formában volt a felszínen kevés $\mathrm{Cu}^{2+}$ jelenlétében. A 
$\mathrm{Cu}^{2+}$ mennyisége arányosan nőtt az idő előrehaladtával, ami a szatellit csúcs intenzitásának növekedéséböl is látszik (10. ábra).

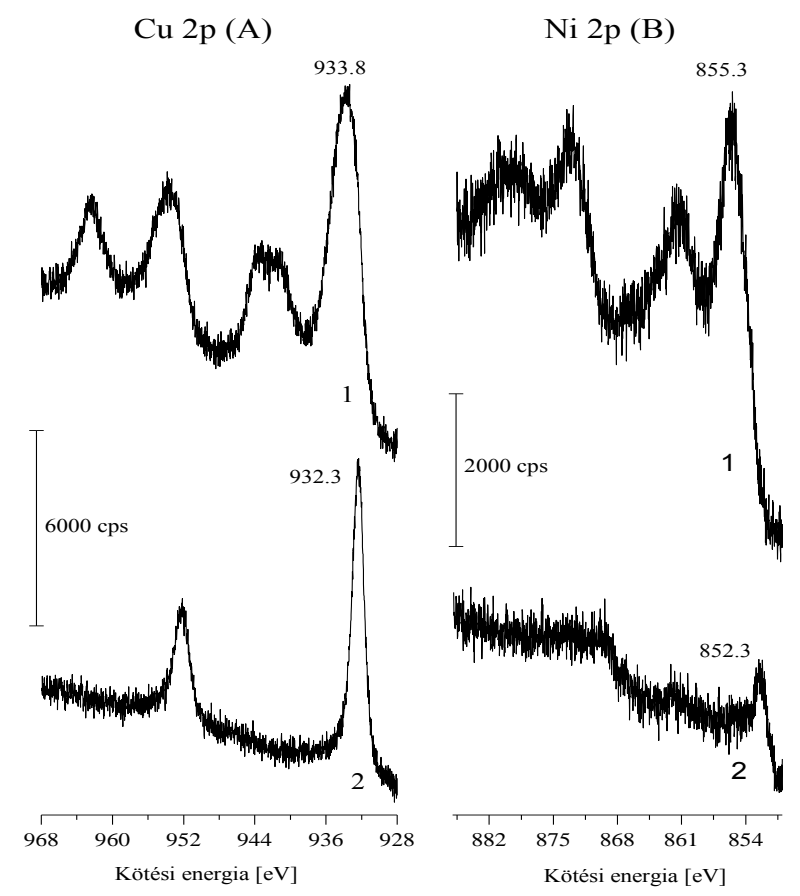

11. ábra $\mathrm{Cu} 2 \mathrm{p}(\mathrm{A})$ és $\mathrm{Ni} 2 \mathrm{p}(\mathrm{B}) \mathrm{XP}$ spektrumok $\mathrm{Cu}-\mathrm{Ni} / \mathrm{MWCNT}$ katalizátoron kiindulási-1 és redukált-2 állapotban

Hasonló spektrumokat rögzítettünk a $\mathrm{Cu}-\mathrm{Ni} / \mathrm{MWCNT}$ katalizátor $\mathrm{Cu}$ komponensére. Figyelembe véve a Ni 2p kötési energiáját a kiindulási minta esetében $\mathrm{NiO}(855,6 \mathrm{eV})$ és kis mennyiségü fémes $\mathrm{Ni}(852,7 \mathrm{eV})[82]$ jelenlétére utalt. A redukált katalizátor $\mathrm{Ni} 2 \mathrm{p}$ spektruma fémes $\mathrm{Ni}(852,7 \mathrm{eV})$ és $\mathrm{Ni}^{2+}(855,6 \mathrm{eV})$ jelenlétét mutatta. Feltehetőleg a Ni egy része nem redukálódott a $\mathrm{H}_{2}$-es előkezelés során (11. ábra). Ezen felül egy új állapot kialakulását is megfigyeltük a fémes Ni-nél alacsonyabb kötési energiánál. Irodalmi adatok szerint a $\mathrm{Cu}-\mathrm{Ni}$ ötvözetben a $\mathrm{Ni} 2 \mathrm{p}$ kötési energiája alacsonyabb értékre tolódhat a $\mathrm{Cu}$ tartalom függvényében, miközben a $\mathrm{Cu}$ csúcs elhelyezkedése viszonylag stabil marad. Ezek az eredmények arra utalnak, hogy a redukált mintában $\mathrm{Cu}-\mathrm{Ni}$ ötvözet képzödött [83]. 

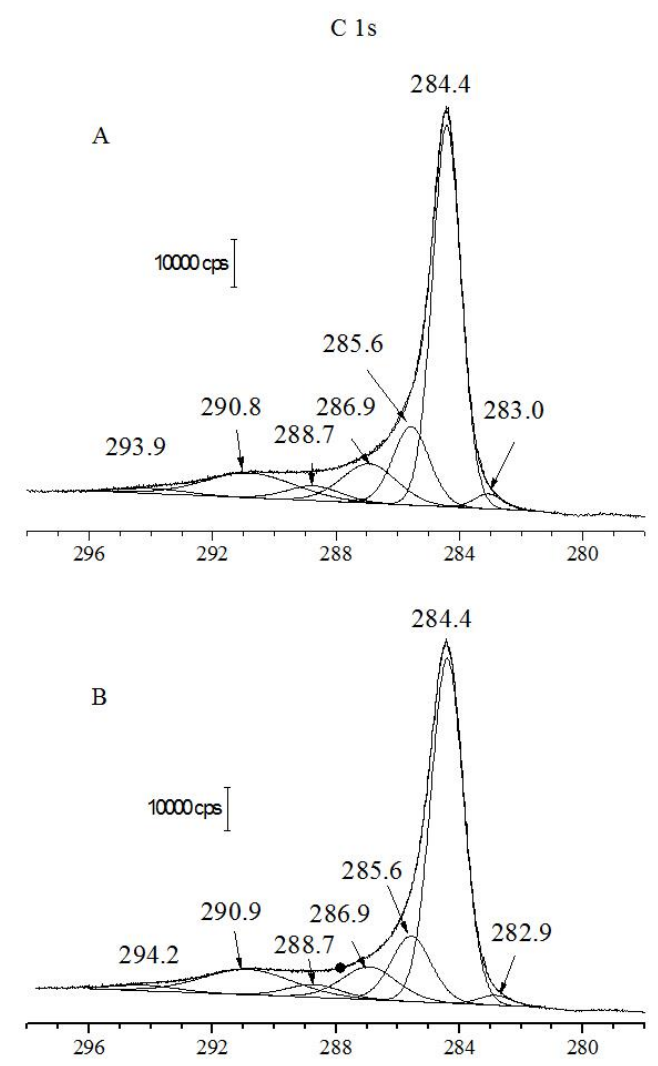

Kötési energia $[\mathrm{eV}]$

\section{2. ábra $\mathrm{C} 1 \mathrm{~s} X P$ spektrumok $\mathrm{Cu} / \mathrm{MWCNT}$ katalizátoron kiindulási (A) és redukált (B) állapotban}

A nagy felbontású szén spektrumokon egy keskeny aszimmetrikus csúcs látható (FWHM = 1,3-1,4 eV), jellegzetes vállal a nagy kötési energiájú oldalon 290,8 eV-nál. A csúcs alakja és a csúcs alatti terület gyakorlatilag konstans maradt az egész kísérlet alatt, a változás bőven 10\%-on belül volt $\mathrm{Cu}$ és $\mathrm{Cu}-\mathrm{Ni} / \mathrm{MWCNT}$ katalizátoron egyaránt (12. ábra).

A redukált minta egy intenzív csúcsot mutatott 284,4 eV-nál. A csúcsfelbontás során 285,6, 286,9, 288,7, 290,8 és 293,3 eV-nál azonosítottunk komponenseket. A 284,4 eV-os csúcs sp2 hibridizált szén C-C és C-H kötéseinek feleltethető meg, a 285,6 eV-nál levő csúcs sp3 hibridizált szénhez köthetö. A 286,9 és 288,8 eV-nál található csúcsok oxigénezett szén kötésekhez rendelhetőek, mint például C-O (fenolos, alkoholos, éteres) és $\mathrm{O}-\mathrm{C}=\mathrm{O}$ (karboxil, észter). A legnagyobb kötési energiájú komponens adszorbeált CO-ból, $\mathrm{CO}_{2}$-ból vagy az aromás gyürük $\pi-\pi *$ átmeneteinek „shake-up” szatellitjeiből származhat [84] [85]. A felbontott spektrumon egy gyenge komponens is megfigyelhető $283 \mathrm{eV}$ körül, amely karbid jellegü anyag jelenlétére utalt [86]. 
$\mathrm{O} 1 \mathrm{~s}$
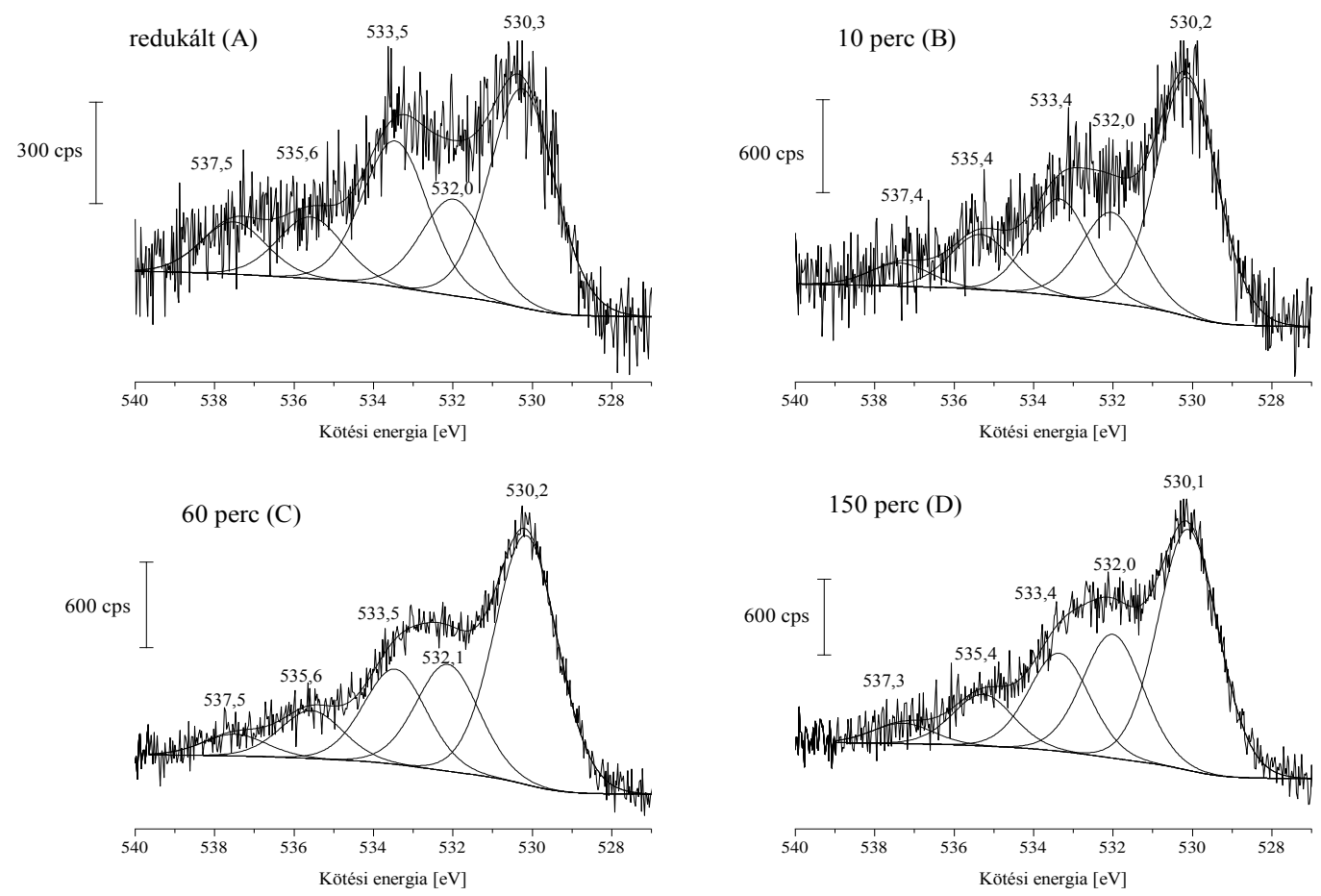

13. ábra $\mathrm{O} 1 \mathrm{~s} X P$ spektrumok $\mathrm{Cu} / \mathrm{MWCNT}$ katalizátoron redukált $(\mathrm{A}), \mathrm{CH}_{3} \mathrm{OH}+\mathrm{CO}+\mathrm{O}_{2}(2: 1: 1)$ reakció 10.

(B), 60. (C), 150. (D) percében 393 K-en

A réz dublett könnyen azonosítható az áttekintő spektrumon, de az $\mathrm{O}$ 1s régió nehezen megkülönböztethető, különösen a kezelt mintákon. A nagy felbontású O 1s spektrum megmutatta ennek a régiónak a meglehetősen komplex alakját, a spektrum hosszan elnyúlik a nagy kötési energiájú oldalon (13. ábra) [81]. A két nagyobb kötési energiájú komponens 535,5 és 537,5 eV körül a Cu LMM Auger sorozat része lehet. Az irodalom [87] szerint egy gyenge csúcs található a 718 eV közelében, amely nagyjából megegyezett a mi eredményünkkel, figyelembe véve az 1253,6 eV-os Mg Ka gerjesztő forrás energiáját. A fent említett csúcsok mellett az $\mathrm{O}$ 1s régió 3 csúcsra bontható (13. ábra). Az O 1s jel intenzitása drasztikusan csökkent a redukció után, az eredeti érték mintegy 25\%-ára, azonban duplájára nőtt a reakció első perceiben, majd változatlan maradt. A másik három komponens pozíciója redukált állapotban, és a reakció közben 530,1-530,3, 532,0-532,1 és 533,4-533,6 eV volt, amelyek közül az első volt a legintenzívebb. Mivel a réz fémes állapotban volt a redukció után, és más elemeket nem találtunk a minta felületén, így mind a három csúcs feltehetően az MWCNT C-O kötéseinek tulajdonítható. Az O 1s elektronok kötési energiája a CuO-ban 529,6 eV-nál van [88], így nem tudtuk meghatározni, hogy a csúcs körülbelül 530 eV-nál tartalmazza-e a $\mathrm{CuO} \mathrm{O}$ 1s jelét. 
O $1 \mathrm{~s}$
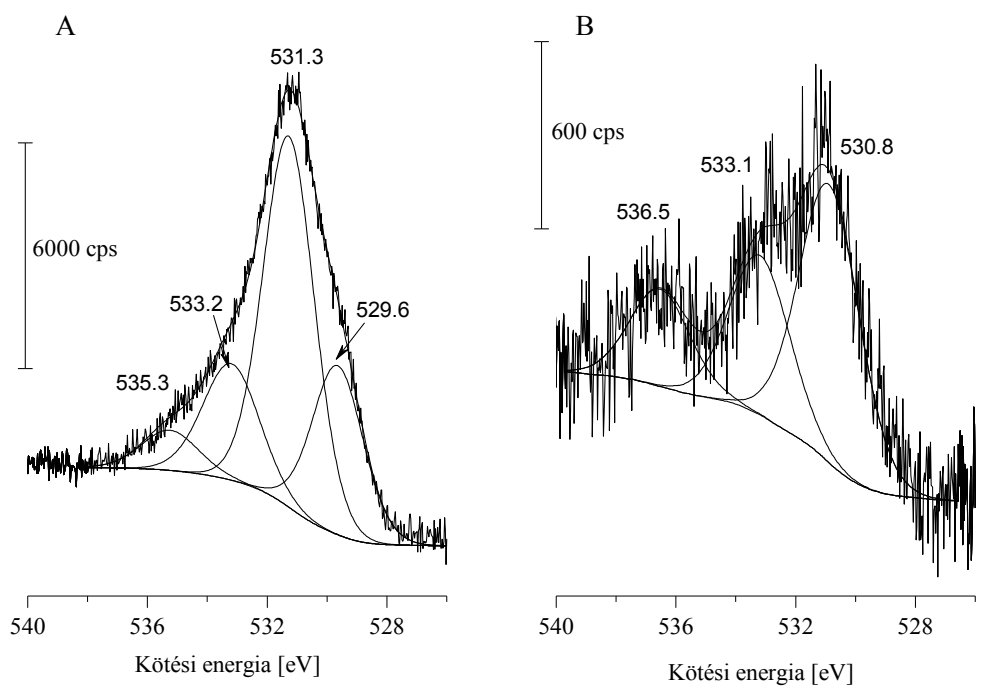

14. ábra O 1s XP spektrumok Cu-Ni/MWCNT katalizátoron kiindulási (A) és redukált (B) állapotban

Összehasonlításképpen a fém nélküli, tiszta MWCNT hordozó XP spektrumát is rögzítettük. Több oxigént figyeltünk meg a tiszta kezeletlen MWCNT esetében, mint a réz tartalmú mintán. A C 1s forma megfelelt a Cu/MWCNT mintán rögzítettnek, de a félértékszélessége valamivel nagyobb volt, körülbelül 1,5 eV. Az O 1s régió Cu/MWCNTre jellemző nagy kötési energiájú nyúlványa teljesen hiányzott. Amikor a $\mathrm{C} 1 \mathrm{~s}$ csúcsot összehasonlítottuk a réz tartalmú spektrumokkal, kiderült, hogy teljesen hiányzott az 530,2 eV-nál levő összetevő. Csak két komponenst lehetett azonosítani, az intenzívebbet 532,1 eV körül és a gyengébbet 536,5 eV-nál.

Az XP spektrumok alapján meghatároztuk a felületi fémkoncentrációkat az előkezelt minták esetében. A redukált $\mathrm{Cu} / \mathrm{MWCNT}$ katalizátoron a $\mathrm{Cu}$ tartalom 0,3 at.\% volt, amíg a $\mathrm{Cu}-\mathrm{Ni} / \mathrm{MWCNT}$ katalizátoron 0,5 at.\% Cu-et és 1 at.\% Ni-t detektáltuk.

Érdekes, hogy a felületi $\mathrm{Cu}$ tartalom körülbelül 100\%-kal nőtt az első órában, majd nagyjából változatlan maradt, enyhén csökkent. A 932,3 eV-os csúcs területe összefüggésben lehet a felületi $\mathrm{Cu}$ tartalommal és a metanol konverzió első órában történt növekedésével, így feltehető, hogy a $\mathrm{CH}_{3} \mathrm{OH}$ fogyás mértéke függ a felületi $\mathrm{Cu}$ atomok mennyiségétől. A reakció első perceiben a DMC képződés igen csekély volt (2. ábra). Az oxidált $\mathrm{Cu}$-re jellemző csúcsok fokozatosan erősödtek, majdnem nulláról, így joggal tételezhetjük fel, hogy a DMC képződési sebessége nem csak a felületi fém 
koncentrációjától függ, hanem annak oxidációs állapotától is. Amikor a katalizátort az előkezelés után újra oxidáltuk, a reakció kezdete előtt a metanol konverzió magasabb volt, de a DMC képződés kezdete a reakció idő ötvenedik percére tolódott. Ez azt jelenti, hogy nem csak teljes mértékben oxidált Cu szükséges a DMC szintézishez.

\subsubsection{Infravörös spektroszkópiás vizsgálatok}

A katalizátor felületén az adszorbeált rétegben a reakció során végbemenő változások nyomon követésére infravörös spektroszkópiás kísérleteket végeztünk.

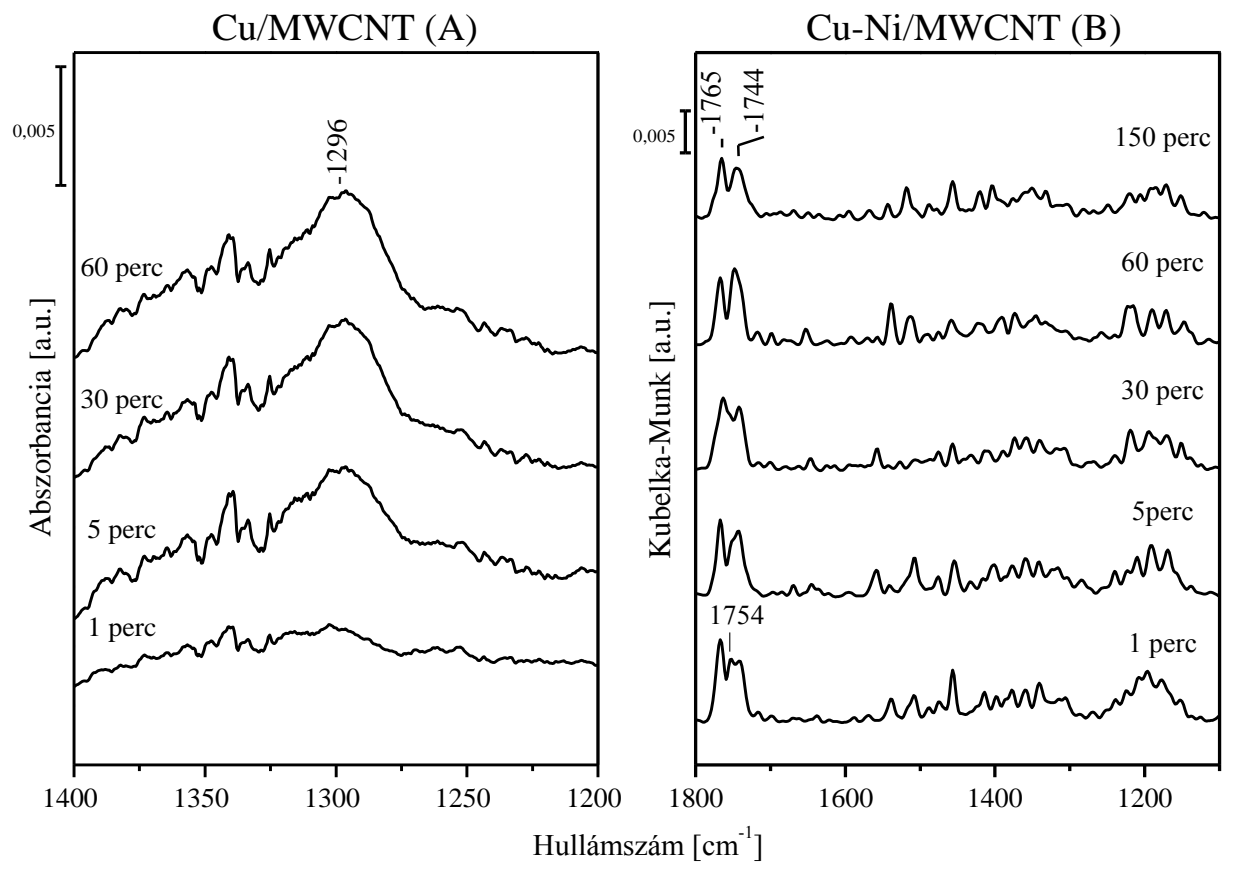

15. ábra IR spektrumok $\mathrm{Cu}(\mathrm{A})$ és $\mathrm{Cu}-\mathrm{Ni} / \mathrm{MWCNT}$ (B) katalizátorokon $\mathrm{CH}_{3} \mathrm{OH}+\mathrm{CO}+\mathrm{O}_{2}(2: 1: 1)$ reakció 1 ., 5., 30. és 60. percében $393 \mathrm{~K}$-en

A DRIFT cellában rögzített spektrumok a Cu/MWCNT katalizátoron 393 K-en lejátszódó reakció alatt főként a gázfázisú $\mathrm{CO}$ és metanol jeleit mutatták. A reagáló gázkeverék gázfázisú spektrumát kivonva a mért spektrumokból gyenge abszorpciót figyeltünk meg 1296, 1742 és $1764 \mathrm{~cm}^{-1}$-nél. Ezeknek a sávoknak az intenzitása enyhén növekedett a reakcióidővel (15. ábra). Amikor a reakció után a cellát átöblítettük He-mal a reakció hőmérsékletén csak kis mértékben csökkent ezeknek a sávoknak az intenzitása.

A Cu-Ni/MWCNT katalizátoron új sávokat detektáltunk 393 K-en a reakció folyamán 1765, 1754, és $1744 \mathrm{~cm}^{-1}$-nél. Ezeknek a sávoknak az intenzitása időben némileg csökkent (15. ábra), majd eltüntek a He-os öblítés hatására. 


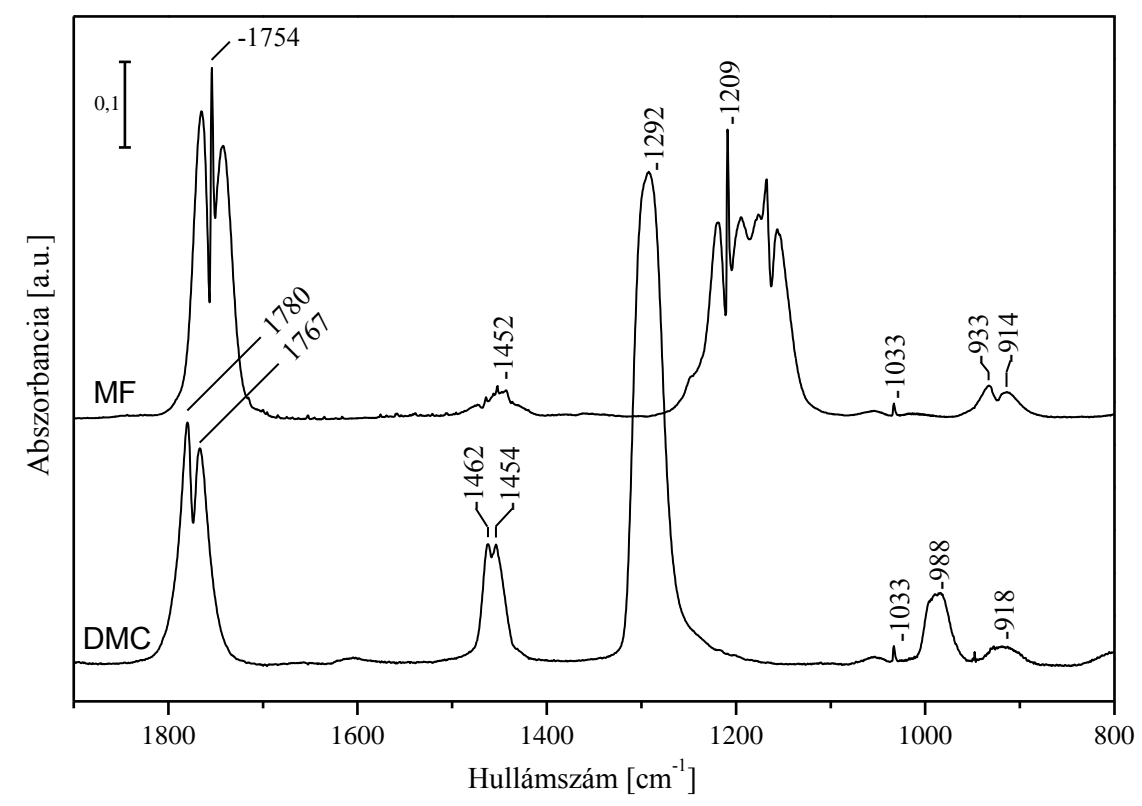

16. ábra MF és DMC adszorpció során rögzített IR spektrumok $\mathrm{Cu} / \mathrm{MWCNT}$ katalizátoron

Az elnyelési sávok azonosításához a fö termékek infravörös spektrumait is rögzítettük. Dimetil-karbonát szobahőmérsékletű adszorpcióját követően a következő sávokat regisztráltuk a 2000-1100 $\mathrm{cm}^{-1}$ régióban: 1780, 1767, 1462, 1454, $1292 \mathrm{~cm}^{-1}$ (16. ábra). Az IR spektrumokat $\mathrm{DMC} / \mathrm{He}$ gőz jelenlétében rögzítettük. A sávok azonosításhoz Kar és munkatársai [89] valamint Bohets és van der Veken [90] munkáit használtuk fel. Az 1780 és $1767 \mathrm{~cm}^{-1}$-nél lévő sávokat a DMC v(C=O) rezgéseinek tulajdonították, az 1463 és 1454 $\mathrm{cm}^{-1}$-nél megjelenő sávokat pedig a DMC cisz-transz és cisz-cisz szerkezetü $\delta_{\mathrm{as}}\left(-\mathrm{CH}_{3}\right)$ rezgéseihez rendelték. Az abszorpció $1299 \mathrm{~cm}^{-1}$-nél az vas (OCO) rezgéshez rendelhető. A MF spektruma 2000 és $1500 \mathrm{~cm}^{-1}$ között 1766, 1754 és $1743 \mathrm{~cm}^{-1}$-nél mutatott sávokat (16. ábra). Wilmhurst szerint [91] ezeket a sávokat a gáz fázisú $\mathrm{MF} \mathrm{C}=\mathrm{O}$ rezgéséhez lehet rendelni.

A fenti adatok világosan mutatják, hogy a dimetil-karbonát adszorbeálódott a felszínen a $\mathrm{Cu} / \mathrm{MWCNT}$ katalizátoron a katalitikus reakció közben, amíg a Cu-Ni/MWCNT katalizátoron csak MF volt kimutatható a gáz fázisban. Ezt támasztják alá a reakció után végzett He-os öblítés után felvett spektrumok. A MF-hoz tartozó sávok rögtön eltüntek, de a DMC viszonylag stabil volt a reakció hőmérsékletén.

A MF és a DMC adszorpciós centrumainak azonosítása nem egyértelmü. Sexton és munkatársai [92] megállapították, hogy a tiszta $\mathrm{Cu}(110)$ felületen a $\mathrm{MF}$ teljesen deszorbeálódik $250 \mathrm{~K}$ alatt. Az oxidált $\mathrm{Cu}$ felület két deszorpciós sávot mutatott 390 és 
$480 \mathrm{~K}$ közelében, metoxi és formiát jelenlétére utalva, amelyet elektron energia veszteségi spektroszkópiai (EELS) mérések eredménye is alátámasztott. Monti és társai [93] kétféle MF abszorpciós formát találtak $\mathrm{Cu} / \mathrm{SiO}_{2}$-on 1726 és $1666 \mathrm{~cm}^{-1}$-nél. Az előbbit megfigyelték tiszta $\mathrm{SiO}_{2}$-on is MF adszorbeáltatása esetén és a felszíni $\mathrm{SiOH}$ csoportokhoz hidrogénkötéssel kapcsolódó MF molekulákhoz rendelték. Az $1666 \mathrm{~cm}^{-1}$-nél lévő sávot karbonil csoporton keresztül felszíni $\mathrm{Cu}$ atomokhoz kapcsolódó $\mathrm{MF} \mathrm{C}=\mathrm{O}$ rezgéséhez rendelték. Ezek a megfigyelések alátámasztják, hogy a MF 1765, 1754, és $1744 \mathrm{~cm}^{-1}$-nél a katalitikus reakció alatt rögzített jelei, már csak a gáz fázisban vannak jelen és nem a felszínen.

Cu/MWCNT-re tiszta metanolt adva 393 K-en jól definiált sávokat figyeltünk meg 2962 és $2843 \mathrm{~cm}^{-1}$-nél, a metanol aszimmetrikus és a szimmetrikus $\mathrm{CH}$ rezgéseinek megfelelően. A He-os öblítés után az intenzitások fokozatosan csökkentek. Hasonló spektrumokat rögzítettünk, amikor a metanolt a minta oxidálása után adtuk a katalizátorra. A tiszta felületre adszorbeált metanol spektrumát kivonva, gyenge abszorpciót figyeltünk meg 3600, 2957, 2939, 2845 és $2821 \mathrm{~cm}^{-1}$-nél. A 2957 és $2845 \mathrm{~cm}^{-1}$-nél levő sávok adszorbeált metanolra jellemzőek, a 2939 és $2821 \mathrm{~cm}^{-1}$-nél rögzítettek pedig metoxi formák kialakulására utalnak. Hasonló eredményeket kaptak különböző $\mathrm{Cu}$ zeolitok esetében is [46] [52]. A gyenge $3600 \mathrm{~cm}^{-1}$-es jel ahhoz a OH csoporthoz rendelhetö, amely a rézhez kötődő oxigén és a metanol disszociációjából keletkező hidrogén reakciója során keletkezik. Ezekből az eredményekböl arra következtethetünk, hogy a metoxi csak oxidált rézen keletkezik. 


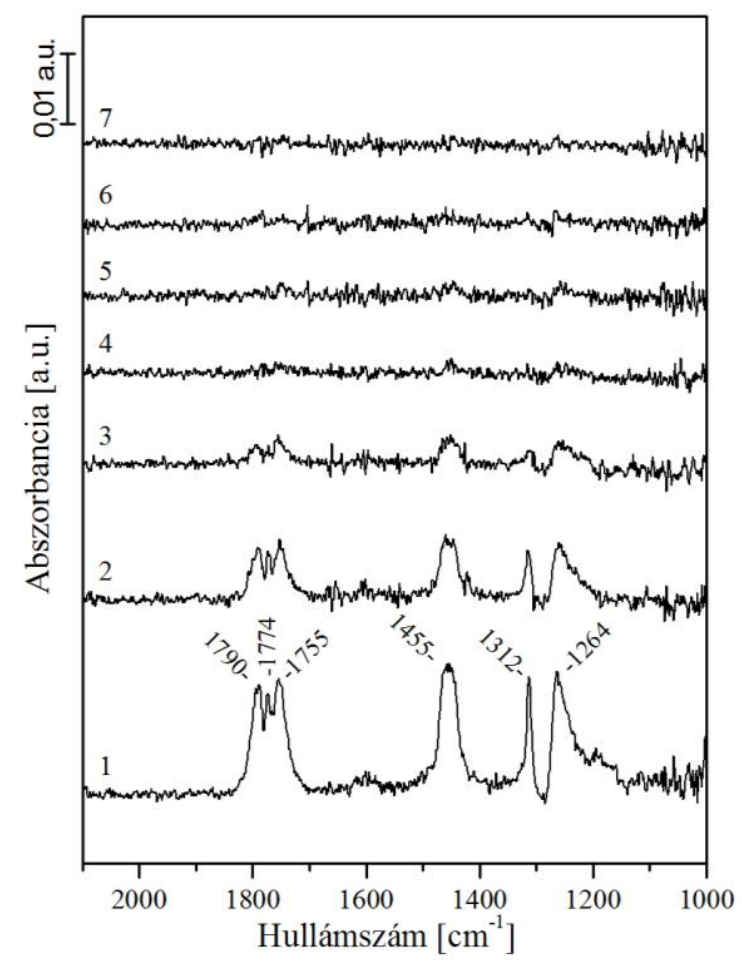

17. ábra $\mathrm{Cu} / \mathrm{MWCNT}$ katalizátoron $\mathrm{DMC}$ bontás során $503 \mathrm{~K}$-en rögzített különbségi IR spektrumok, amelyeket az őket követőekből kivontuk(10-5 min (1), 20-10 min (2), 30-20 min (3), 60-50 min (4) 90-80 $\min (5), 120-110 \min (6), 180-170 \min (7))$

A DMC bontás során rögzített infravörös spektrumok $\mathrm{Cu}$ /MWCNT katalizátoron $503 \mathrm{~K}$-en főleg a gázfázisú DMC-ra jellemző sávokat mutatták, amelyeket az előbbiekben meghatároztunk. A reakció alatt 10 percenként rögzítettünk spektrumokat és minden spektrumot kivontuk az azt követőből. A 2000-1100 $\mathrm{cm}^{-1}$ közötti régióban abszorpciós sávokat figyeltünk meg 1790, 1774, 1755, 1455, 1312, $1264 \mathrm{~cm}^{-1}$-nél, amelyek intenzitása csökkent az idő előrehaladtával, majd 30 perc után a spektrumok már nem változtak tovább (17. ábra). Az 1780, 1765, 1462, 1453 és $1306 \mathrm{~cm}^{-1}$ sávok a már meghatározott DMC rezgésekhez köthetőek. Az 1177 és $1100 \mathrm{~cm}^{-1}$-nél detektált sávok a $\mathrm{DME} \rho\left(\mathrm{CH}_{3}\right)$ és $v_{\mathrm{a}}(\mathrm{COC})$ rezgéseitől származnak.

\subsubsection{DMC TPD}

A DMC hőmérséklet programozott deszorpcióját áramlásos rendszerben tanulmányoztuk. A DMC adszorpcióját Cu/MWCNT katalizátoron és Cu-Ni/MWCNT katalizátoron $323 \mathrm{~K}$ en hajtottuk végre. A megkötött DMC mennyisége $26-29 \mathrm{mg} / \mathrm{g}$ volt. 

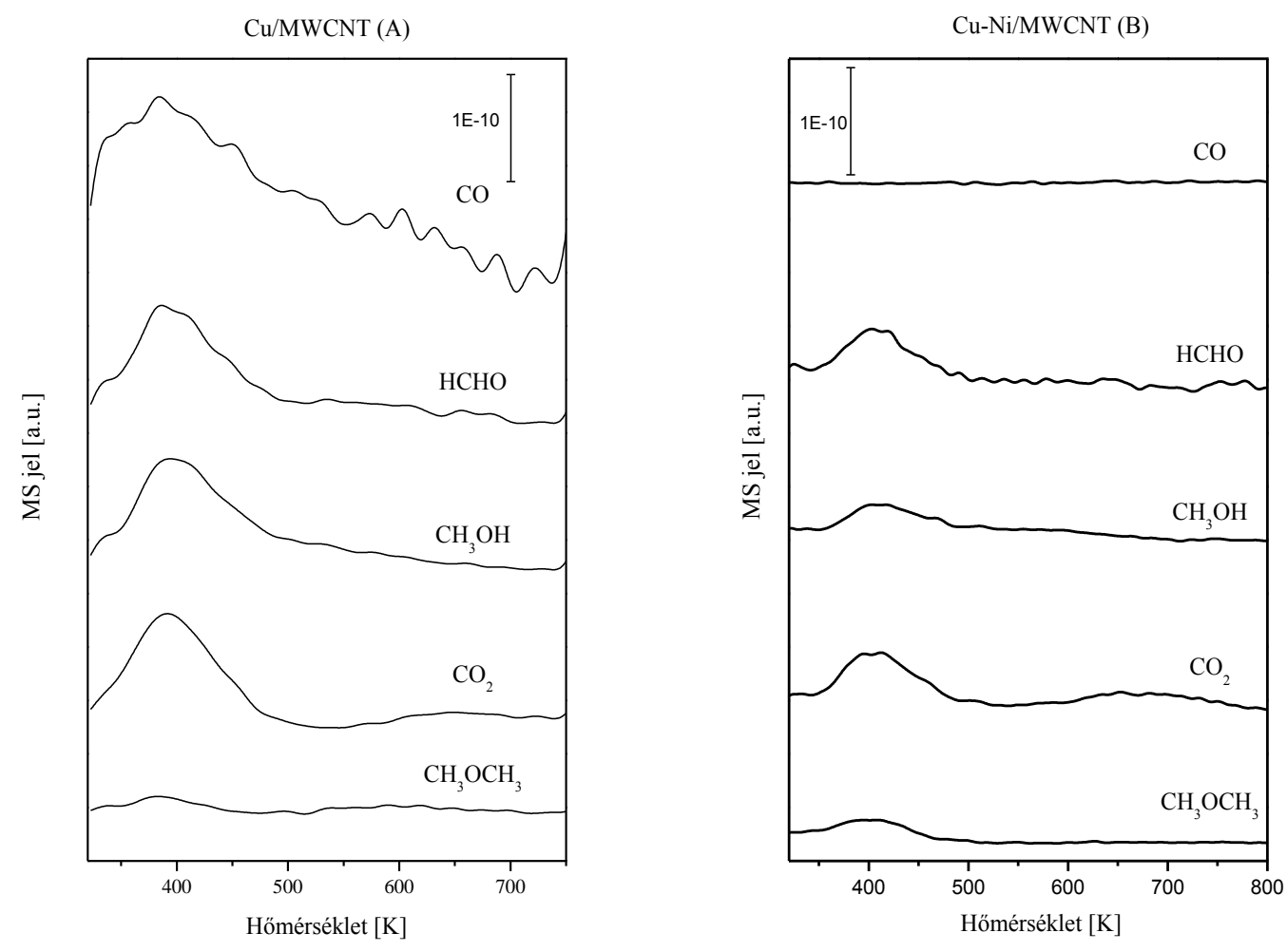

18. ábra Szobahőmérsékleten adszorbeáltatott DMC TPD spektrumai $\mathrm{Cu}(\mathrm{A})$ és $\mathrm{Cu}-\mathrm{Ni} / \mathrm{MWCNT}(\mathrm{B})$

katalizátoron

A katalizátort He áramban felfütve $330 \mathrm{~K}$ felett metanol $(\mathrm{m} / \mathrm{e}=31,32,15)$, szén-dioxid $(\mathrm{m} / \mathrm{e}=44)$, dimetil-éter $(\mathrm{m} / \mathrm{e}=45,46)$ és formaldehid $(\mathrm{m} / \mathrm{e}=29,30)$ deszorpciót figyeltünk meg mindkét esetben. $\mathrm{Cu} / \mathrm{MWCNT}$ katalizátoron szén-monoxid $(\mathrm{m} / \mathrm{e}=28$, más termékek fragmentjeit, mint például a $\mathrm{CO}_{2}$-ét, levontuk) képződést is megfigyeltük. A csúcs maximum 393 K körül volt (18. ábra). DMC képződést nem detektáltunk, amíg az m/e=59-

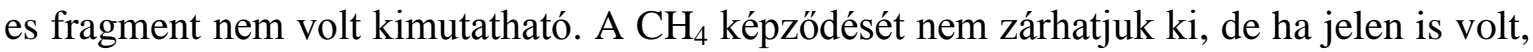
a mennyisége a többi termékhez viszonyítva csekély. A DMC-ra jellemző fragmentek megjelenésének hiánya arra utal, hogy az adszorbeált DMC teljesen elbomlott a deszorpció során.

Magasabb hőmérsékleten (393 K) adszorbeáltatva a DMC-ot, a TPD során nem találtunk termékeket vagy a kimutatási határ alatt voltak, és nem tapasztaltunk súlyváltozást sem. Ez a megfigyelés alátámasztja a TPD eredményeket, amely szerint a DMC nem lép kölcsönhatásba a felülettel ezen a hőmérsékleten. 


\subsection{7 $\mathrm{NH}_{3}$ és $\mathrm{CO}_{2} \mathrm{TPD}$}

Mint az irodalmi összefoglalóban említettük, a DMC szintézisét [18] [21] [23] [69] és bomlását [77] [78] a katalizátor sav-bázis karaktere befolyásolja.

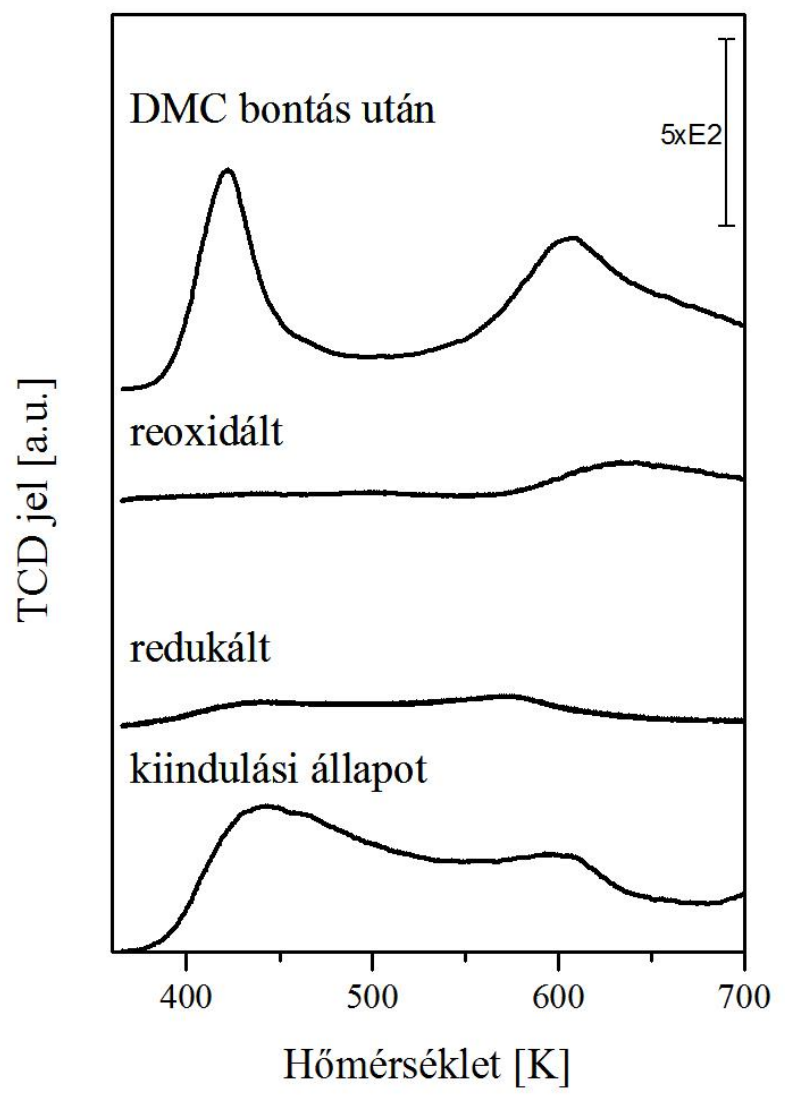

19. ábra $\mathrm{NH}_{3} \mathrm{TPD} \mathrm{Cu} / \mathrm{MWCNT}$ katalizátoron előkezelés valamint DMC bontás után

A $\mathrm{Cu} / \mathrm{MWCNT}$ katalizátor felületi savas és bázikus tulajdonságait $\mathrm{NH}_{3}$ és $\mathrm{CO}_{2}$ TPD vizsgálatokkal határoztuk meg. A deszorpciós hőmérsékletek a savas és bázikus helyek erősségét, a deszorpciós görbe csúcs alatti területe pedig a savas és bázikus helyek számát mutatja.

A $\mathrm{Cu} / \mathrm{MWCNT}$ esetében kapott $\mathrm{NH}_{3}$ TPD görbe a katalizátor felületén kétféle savas hely $\left(\mathrm{T}_{\max }=443\right.$ és $\left.603 \mathrm{~K}\right)$ létezését mutatta a kezeletlen minta esetében (kiindulási állapotban, He áramban 873 K-re felfütve), amelyeknek a mennyisége jelentősen csökkent a redukció után. Az elökezelés után újra oxidálva a mintát nem kaptunk változást, azonban a DMC bontás után rögzített görbe egyértelműen a savas helyek újbóli erőteljes megjelenését mutatta (19. ábra). 
Az eredmények hasonlóak az XPS mérések (10. ábra) esetében tett megfigyelésekkel. A savas helyek erősen jelen voltak a felületen a kiindulási állapotban, majd a redukció után nem voltak észlelhetőek. Végül a reakció alatt folyamatosan nőtt a számuk, mint ahogy azt az előbbiekben leírtuk.

Liu és munkatársai [64] a CuCl/AC vizsgálata során megfigyelték, hogy a kalcinálási hőmérséklet erőteljesen befolyásolta a savas helyek számát a katalizátoron. A hőmérséklet növekedésével a savas helyek száma csökkent. A gyengébben savas helyek könnyebben tűntek el a kalcinálással. Hasonló megfigyeléseket tettek Bian és társai [35], $873 \mathrm{~K}$ felett kezelt mintákon szinte semmilyen deszorpciós csúcsot nem tudtak kimutatni, ami szintén azt jelzi, hogy a kalcinálási hőmérséklet növelése a katalizátor felületi savasságának csökkenését eredményezte.

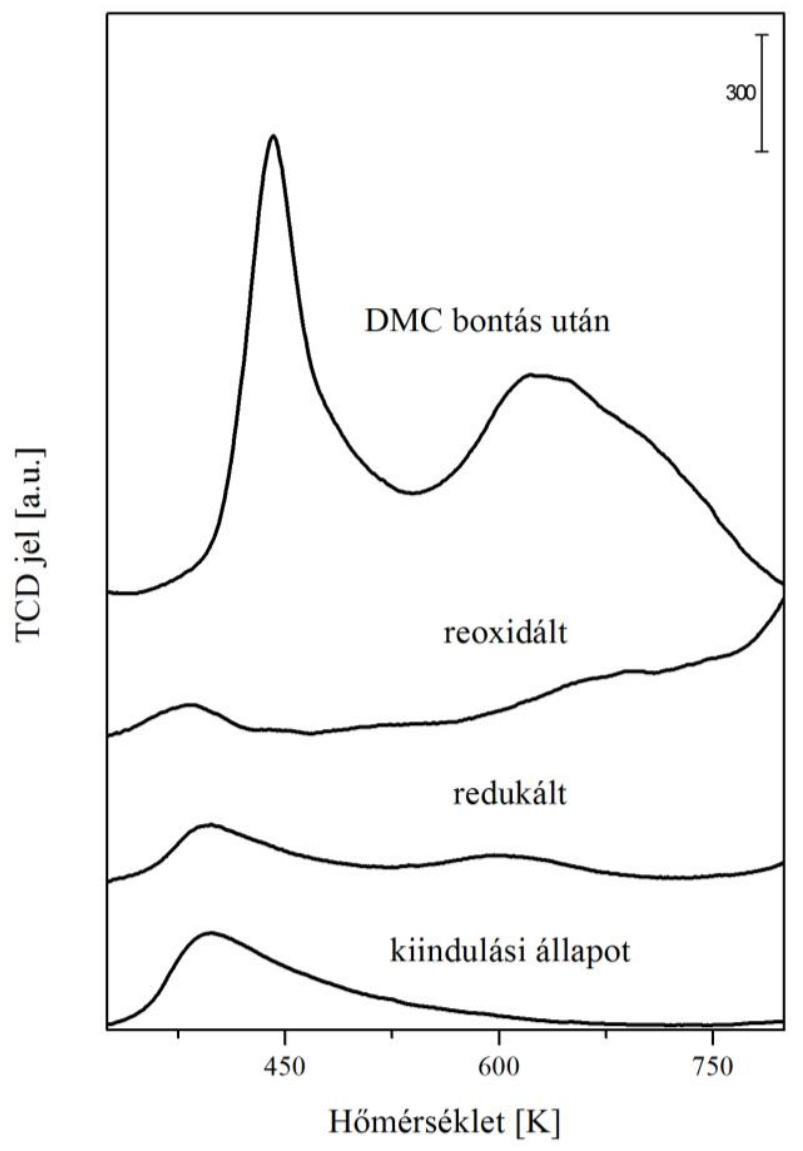

20. ábra $\mathrm{CO}_{2} \mathrm{TPD} \mathrm{Cu} / \mathrm{MWCNT}$ katalizátoron különböző elökezelés valamint DMC bontás után

$\mathrm{A} \mathrm{CO}_{2}$ TPD görbéjén $\mathrm{Cu} / \mathrm{MWCNT}$ katalizátoron egy deszorpciós csúcsot detektáltunk 394 K körül a kezeletlen mintán (kiindulási állapotban) (20. ábra). Redukció hatására ennek a csúcsnak az intenzitása jelentősen lecsökkent és $603 \mathrm{~K}$ körül egy új deszorpciós formát 
azonosítottunk. A reoxidált felület esetében a csúcsok maximum hőmérséklete magasabb értéken volt, intenzitásuk jelentősen nem változott. A DMC bontás után rögzített spektrumon két intenzív bázikus centrumot azonosítottunk, amelyeket a 446 és 629 K-nél jelentkező csúccsal jellemezhetünk (20. ábra). A magasabb hőmérsékletű csúcsmaximum jelentheti a kiindulási mintához képest új bázikus helyek kialakulását, de valószínűbb, hogy ezt a változást a deszorbeálódó $\mathrm{CO}_{2}$ mennyiségének növekedése okozta.

\subsection{Norit hordozós katalizátorok vizsgálata}

\subsubsection{Metanol oxidativ karbonilezése}

A reakciókat atmoszferikus nyomáson, általában $393 \mathrm{~K}$-en hajtottunk végre $\mathrm{Cu}, \mathrm{Ni}$ és $\mathrm{Cu}$ $\mathrm{Ni} /$ Norit katalizátorokon.
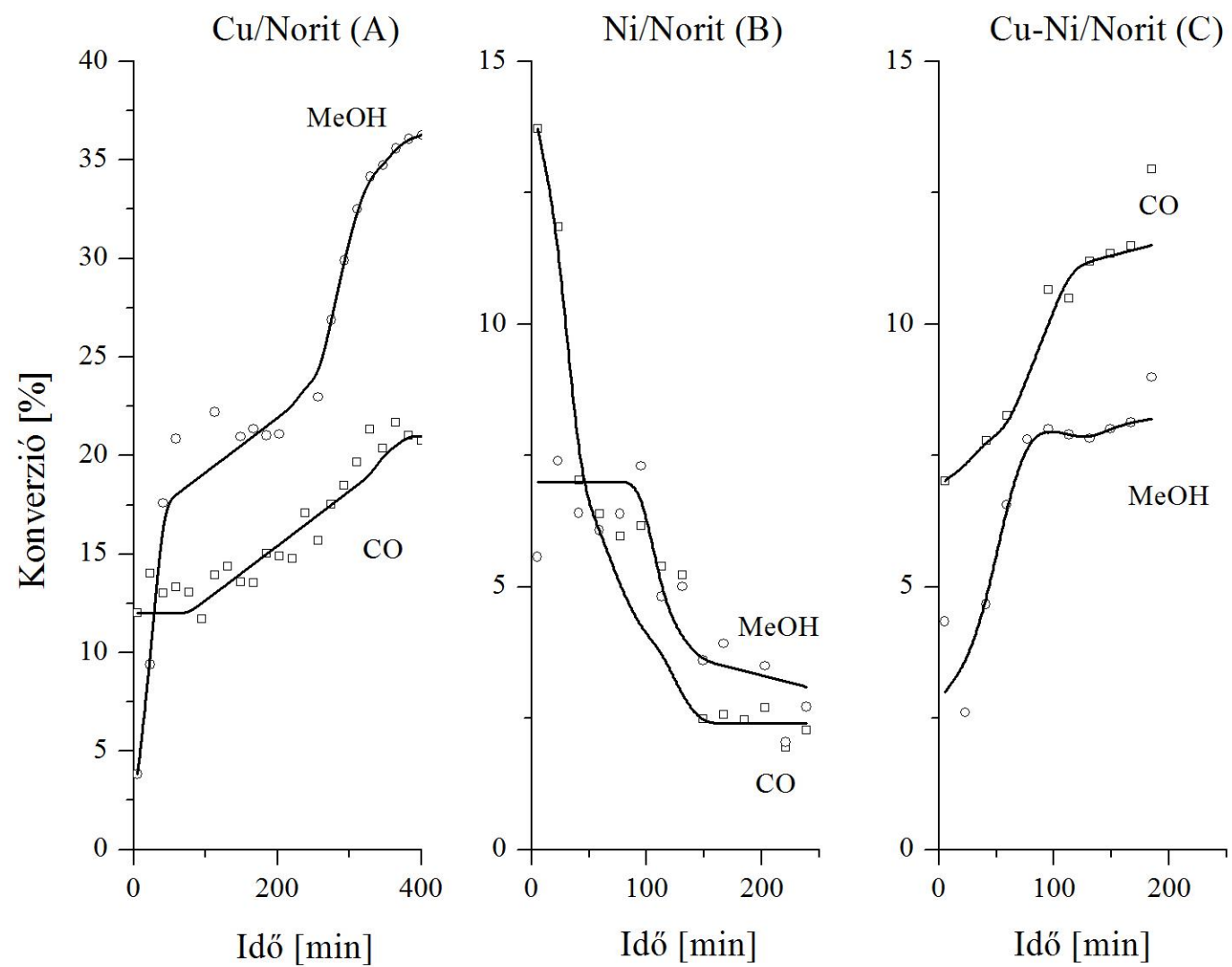

21. ábra $\mathrm{CO}$ és metanol konverziója $\mathrm{Cu}(\mathrm{A}), \mathrm{Ni}(\mathrm{B}), \mathrm{Cu}-\mathrm{Ni} / \mathrm{Norit}(\mathrm{C})$ katalizátorokon $\mathrm{CH}_{3} \mathrm{OH}+\mathrm{CO}+\mathrm{O}_{2}$

(2:1:1) reakció során $393 \mathrm{~K}$-en

A Norit hordozós katalizátorokon a fö termék $\mathrm{CO}_{2}, \mathrm{DMC}$ és MF volt. Kis mennyiségben DMM-t és nyomokban DME-t is kimutattunk. A metanol konverziója Cu/Norit esetében, amely növekedett a reakció közben, 400 perc elteltével 35\%-ot ért el. 
A Ni/Noriton a metanol konverzió körülbelül 13\% volt a reakció elején, majd 2 órán át folyamatosan csökkent, végül 150 perc eltelte után elérte a közel állandó aktivitást, körülbelül 2,5\%-ot.

$\mathrm{Cu}-\mathrm{Ni}$ /Norit katalizátoron a metanol konverzió 11\%-ig növekedett a reakció első 130 percében, majd közel állandó maradt.

A CO konverzió a metanol konverzióhoz hasonlóan változott. A Ni/Norit katalizátoron végrehajtott kísérletek során időben csökkent, de a Cu tartalmú mintáknál a konverziók az idő függvényében növekedtek (21. ábra).
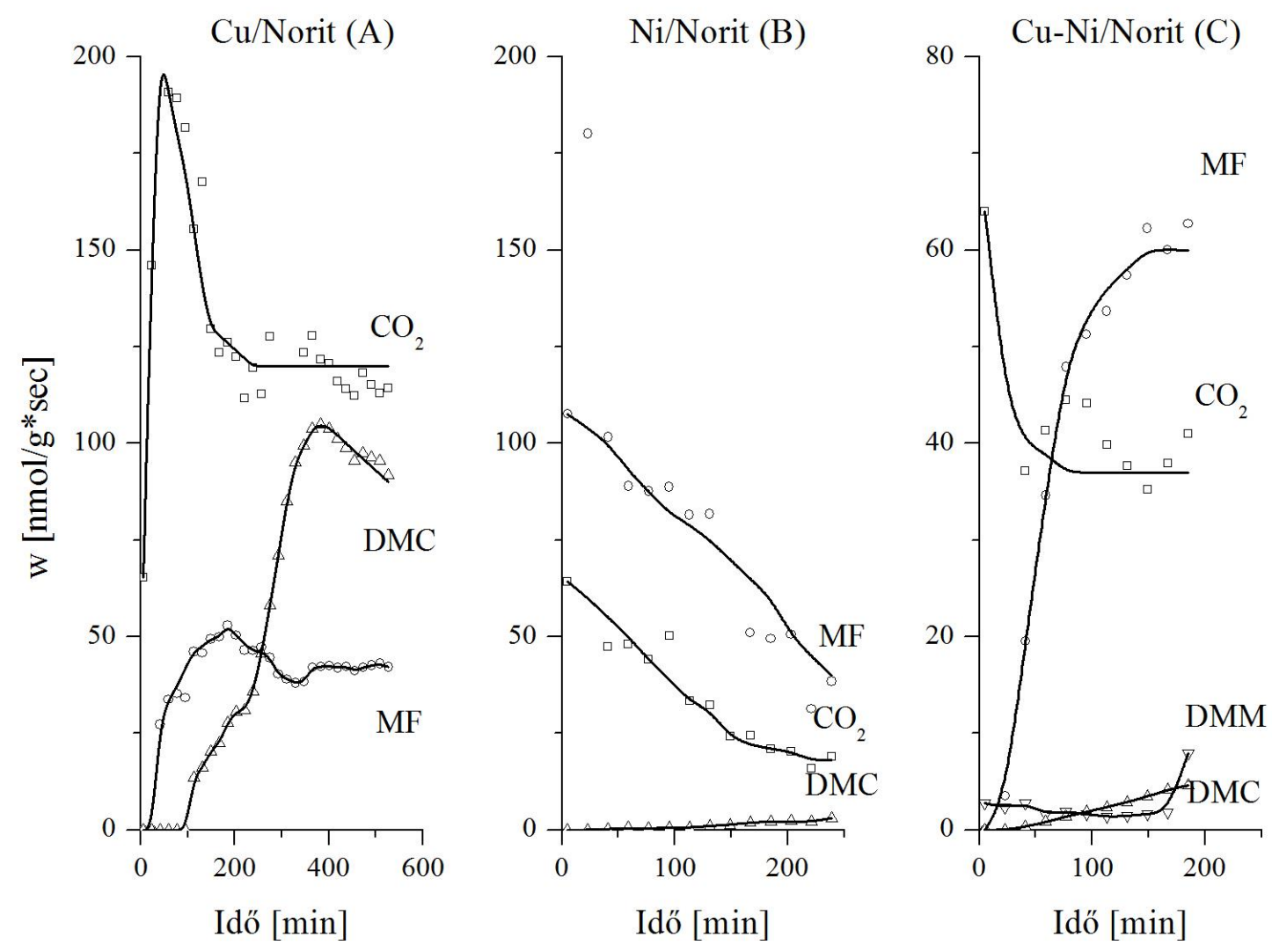

22. ábra $\mathrm{DMC}, \mathrm{MF}$ és $\mathrm{CO}_{2}$ képződési sebességei $\mathrm{Cu}(\mathrm{A}), \mathrm{Ni}(\mathrm{B}), \mathrm{Cu}-\mathrm{Ni} / \mathrm{Norit}(\mathrm{C})$ katalizátorokon

$\mathrm{CH}_{3} \mathrm{OH}+\mathrm{CO}+\mathrm{O}_{2}(2: 1: 1)$ reakció során $393 \mathrm{~K}$-en

A $\mathrm{Cu} /$ Noriton a $\mathrm{CO}_{2}$ képződési sebessége a reakció első órájában növekedett, majd csökkent, 3 óra eltelte után közel állandó maradt, amíg a MF képződési sebessége kissé emelkedett az első órában, majd változatlan maradt. A reakció első közel 100 percében 
nem tapasztaltunk DMC képződést, majd ugrásszerü növekedést figyeltünk meg a reakció 350. percéig, utána enyhén csökkenni kezdett.

A Ni/Norit esetében a MF és a $\mathrm{CO}_{2}$ képződés időben csökkent, ugyanakkor DMC alig keletkezett. A kitermelés sokkal gyengébb volt, mint a $\mathrm{Cu} /$ Norit esetében.

A $\mathrm{Cu}-\mathrm{Ni} /$ Noriton a $\mathrm{MF}$ kialakulása nagymértékben nőtt, a $\mathrm{CO}_{2}$ csökkenő tendenciát mutatott időben. A DMC és a DMM képződési sebessége alacsony szinten alig változott (22. ábra).

Kitünik a fenti adatokból, hogy ugyanolyan körülmények között a DMC képződési sebessége több mint tízszer nagyobb volt a $\mathrm{Cu} / \mathrm{Noriton}$, mint a $\mathrm{Ni} / \mathrm{Norit}$ vagy $\mathrm{Cu}-\mathrm{Ni} / \mathrm{Norit}$ esetében 5 óra eltelte után.
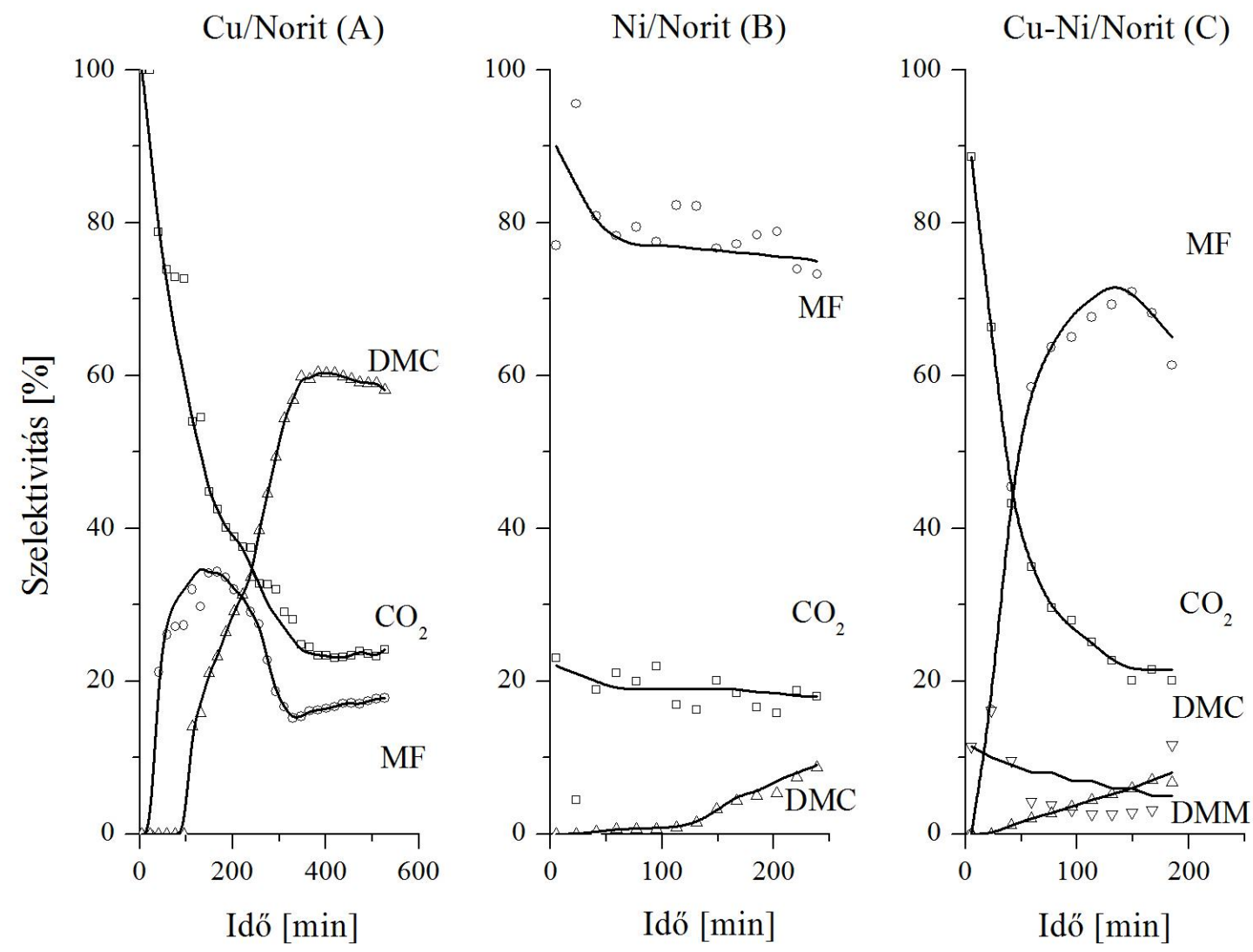
A Ni/Noriton a MF (90-ről 74\%-ra) és a $\mathrm{CO}_{2}$ (22-ről 19\%-ra) szelektivitása időben csökkent (23. ábra). Az első 100-120 percben csak kis mennyiségü DMC keletkezését detektáltuk, később növekvő szelektivitással is csak 10\%-ot ért el a reakció 250 percére.

A 23. ábra a $\mathrm{Cu}-\mathrm{Ni} / \mathrm{Norit}$ felületen keletkezett termékek szelektivitásának változásait mutatja. A DMC szelektivitás kis mértékben, a MF nagymértékben növekedett a reakció során, amíg a $\mathrm{CO}_{2}$ szelektivitása folyamatosan csökkent.

A DMC kitermelés a $\mathrm{Cu} /$ Noriton volt a legnagyobb az állandó aktivitású szakaszban, atmoszferikus nyomáson $(\sim 13,2 \%)$. A különböző katalizátorokon kapott hozamokat egymáshoz viszonyítva a következő sorrendet állíthatjuk fel:

\section{$\mathrm{Cu} / \mathrm{Norit}>\mathrm{Cu}-\mathrm{Ni} /$ Norit $>\mathrm{Ni} / \mathrm{Norit}$}

$\mathrm{A} \mathrm{Cu} /$ Noriton légköri nyomáson elért DMC kitermelés összehasonlítható a $\mathrm{Cu} \mathrm{Y}$ zeoliton kapott értékkel $(13,1 \%)$ [49], vagy az $\mathrm{AC}$ hordozós $\mathrm{CuCl}_{2}$ katalizátoron közölt eredményekkel (16,3\%) [67], amelyet 2,3 bar nyomáson autoklávban mértek. A DMC kitermelés meghaladta a $\mathrm{Cu}-\mathrm{Ni} / \mathrm{MWCNT}$ katalizátoron nagy nyomáson [94] vagy a fentiekben bemutatott $\mathrm{Cu} / \mathrm{MWCNT}$ katalizátoron atmoszferikus nyomáson általunk mért DMC kitermelést $(1,2 \%)$.

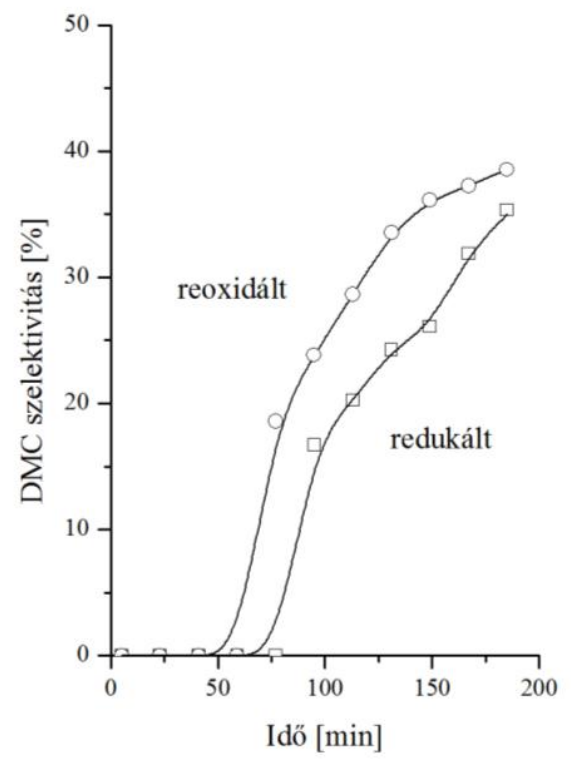


Vizsgáltuk a katalizátor előkezelésének hatását a DMC szintézisére a Cu/Norit esetében. Alacsonyabb hőmérsékletű redukálás (773 vagy 673 K) a DMC képződés indukciós idejét lényegesen elnyújtotta (előkezelés után 280 perc volt) valamint a DMC szelektivitása az állandó aktivitású szakaszban kisebb, $20 \%$ alatti volt $60 \%$ helyett. Előkezelés nélkül a katalizátor teljesen inaktív volt a DMC szintézisben. Amikor az elökezelés után a katalizátort a reakció előtt oxidáltuk, a DMC képződés indukciós ideje enyhén csökkent (24. ábra).

A metanol oxidatív karbonilezése során keletkezett termékek képződési mechanizmusának jobb megértése érdekében vizsgáltuk azonos kinetikai paraméterek mellett a metanol oxidációját is a $\mathrm{Cu} /$ Norit katalizátoron $393 \mathrm{~K}$-en. A metanol konverzió hasonlóan alakult, mint a metanol oxidatív karbonilezése során, bár ebben az esetben MF volt a fö termék, csak kis mennyiségü $\mathrm{CO}_{2}$ és nyomnyi mennyiségü FA keletkezett. A termékképződés az első 30 percben csökkent, azután állandó maradt. A metanol karbonilezése során kizárólag $\mathrm{CO}_{2}$ keletkezett.

A tiszta hordozó aktivitását is teszteltük a metanol oxidatív karbonilezése során, a fent említett kísérleti körülmények között. Ebben az esetben csak kis mennyiségü $\mathrm{CO}_{2}$ keletkezett.

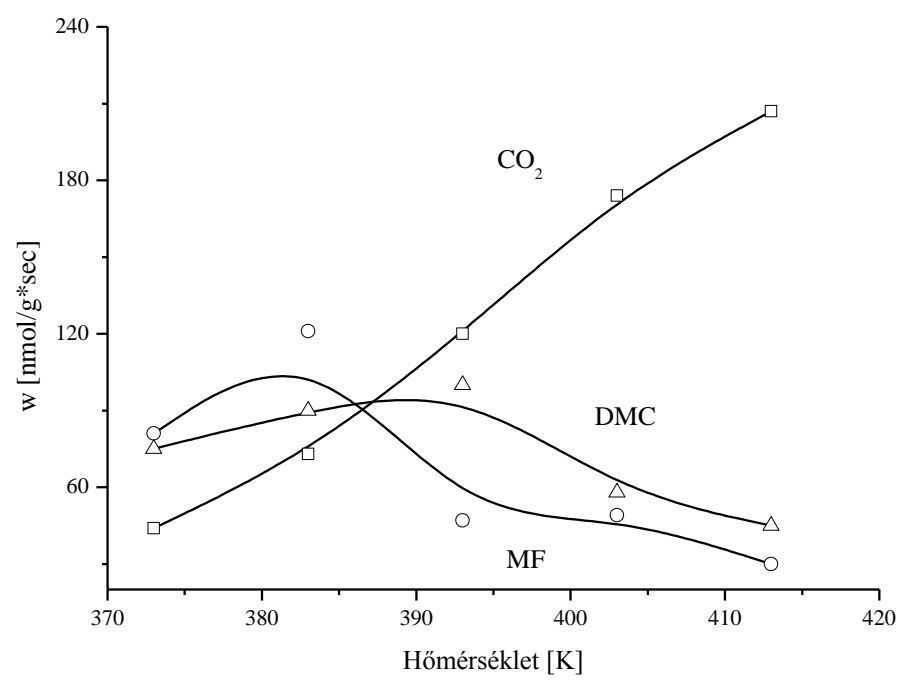


Kísérleteink során a legjobb eredményeket $\mathrm{Cu} /$ Norit katalizátor esetében értük el, így ezen a mintán részletesen tanulmányoztuk a metanol oxidatív karbonilezését. A reakció hőmérsékletet 373-413 K között változtattuk. Minden egyes kísérletet friss katalizátoron végeztünk. Különböző hőmérsékleteken a közel állandó aktivitású szakaszban kapott értékeket hasonlítottuk össze. $\mathrm{A} \mathrm{CO}_{2}$ mennyisége folyamatosan emelkedett a hőmérséklet függvényében, de a MF és a DMC képződési sebesség görbéinek 383 illetve 393 K-nél maximuma volt (25. ábra).

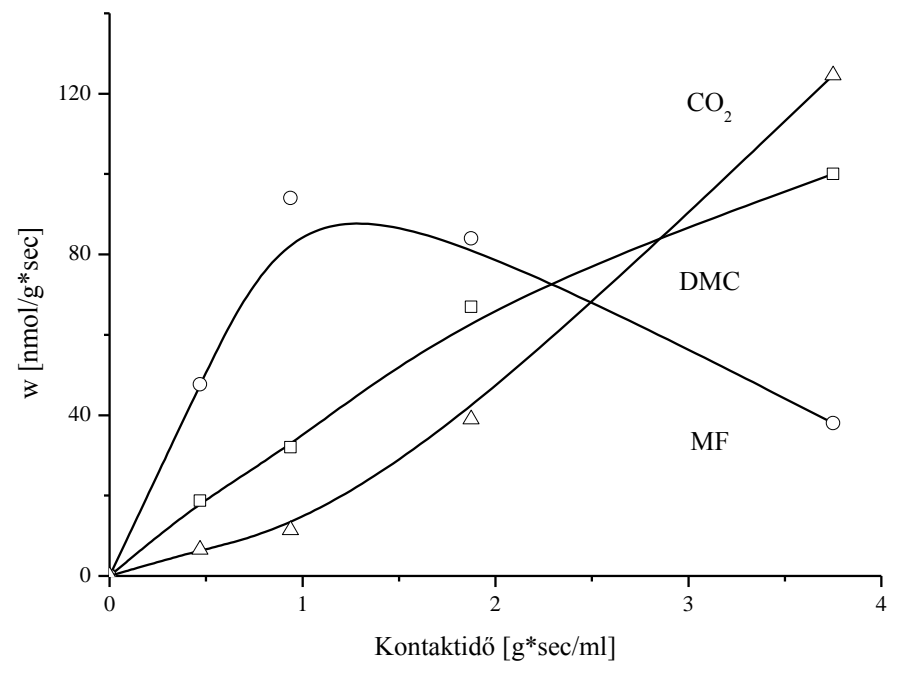

26. ábra DMC, MF és $\mathrm{CO}_{2}$ képződési sebességei kontaktidő függvényében $393 \mathrm{~K}$-en $\mathrm{CH}_{3} \mathrm{OH}+\mathrm{CO}+\mathrm{O}_{2}$

$(2: 1: 1)$ reakció során $\mathrm{Cu} /$ Norit katalizátoron

A térsebesség változtatása eltérő hatást gyakorolt a termékeloszlásra a metanol oxidatív karbonilezése során. A DMC és a $\mathrm{CO}_{2}$ képződési sebessége közel lineárisan nőtt a kontaktidő növelésével. Ezzel szemben a MF képződési sebessége maximum görbe szerint változott (26. ábra). 


\subsubsection{DMC katalitikus bontása}

A

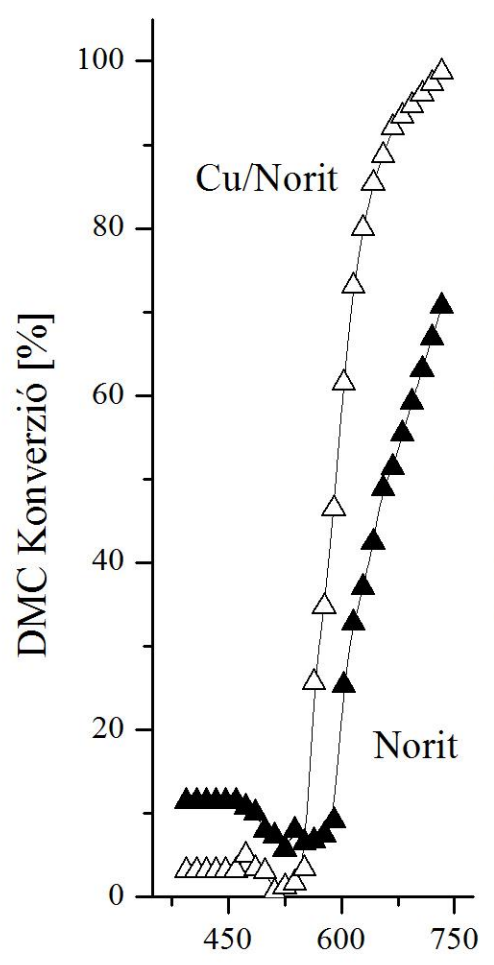

B (Norit)

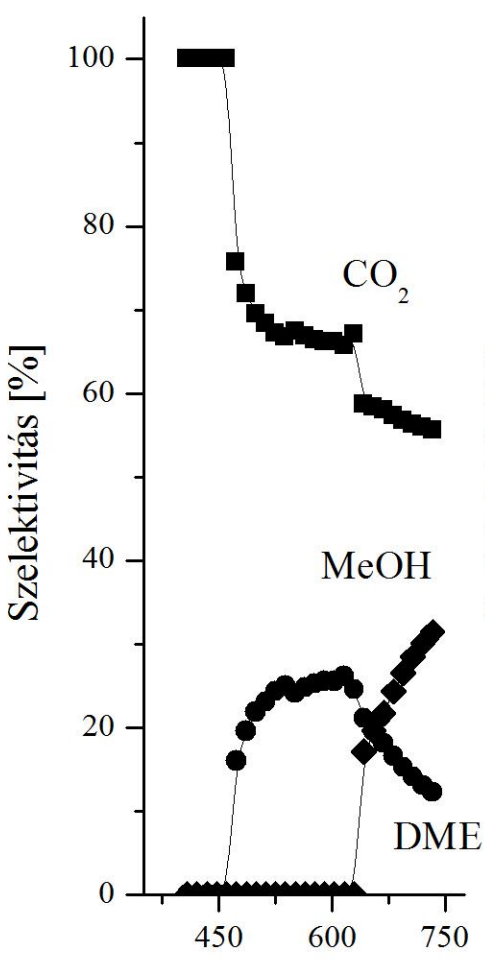

Hőmérséklet
$\mathrm{C}(\mathrm{Cu} /$ Norit $)$

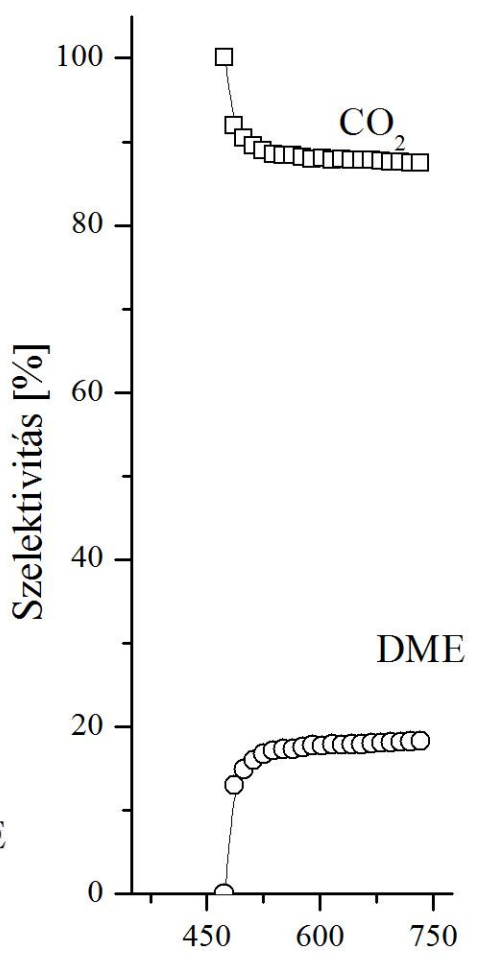

27. ábra DMC konverziója Noriton és Cu/Noriton (A), a keletkezett termékek szelektivitásainak változása Noriton (B), és $\mathrm{Cu} /$ Noriton (C) DMC bontás során a hőmérséklet függvényében

A 27. ábra a DMC konverziót és termékek szelektivitásait mutatja $\mathrm{Cu} / \mathrm{Norit}$ és tiszta Norit minta esetében a hőmérséklet programozott reakciók során. A fö termék $\mathrm{CO}_{2}, \mathrm{DME}$ és metanol volt. A $\mathrm{Cu} /$ Norit és tiszta Norit esetében a konverziók csak $550 \mathrm{~K}$ felett kezdtek emelkedni, ugrásszerü növekedést figyeltünk meg 550 és $720 \mathrm{~K}$ között. A tiszta hordozó kevésbé volt aktív megegyező kinetikai paraméterek között.

Alacsonyabb hőmérsékleten minden esetben $\mathrm{DME}$ és $\mathrm{CO}_{2}$ képződött. Magasabb hőmérsékleten a hordozón és a $\mathrm{Cu}$ /Norit esetében a termékek szelektivitásában jelentős különbséget figyeltünk meg. A hordozón a DME szelektivitás csökkent, a metanol szelektivitás nőtt. 


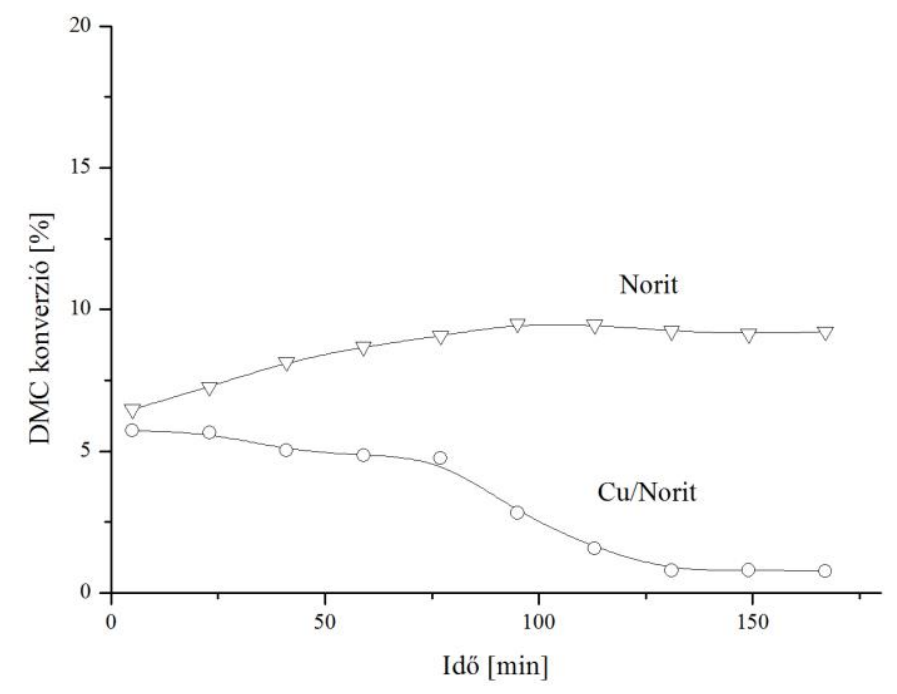

28. ábra DMC konverziója Noriton és Cu/Noriton izoterm DMC bontás során $473 \mathrm{~K}$-en

A DMC bontását részleteiben tanulmányoztuk izoterm körülmények között a $\mathrm{Cu} / \mathrm{Norit}$ katalizátoron és a tiszta hordozón is $473 \mathrm{~K}$-en. A DMC konverzió $\mathrm{Cu} / \mathrm{Norit}$ esetében jelentősen csökkent, a tiszta hordozón viszonylag stabil volt (28. ábra). A termék mindkét esetben DME és $\mathrm{CO}_{2}$ volt, a szelektivitásuk is hasonlóan alakult, amely alátámasztja az alábbi egyensúlyi reakció lezajlását a DMC bomlása során [76]:

$$
\mathrm{CO}\left(\mathrm{CH}_{3} \mathrm{O}\right)_{2} \leftrightharpoons \mathrm{CO}_{2}+\left(\mathrm{CH}_{3}\right)_{2} \mathrm{O}
$$

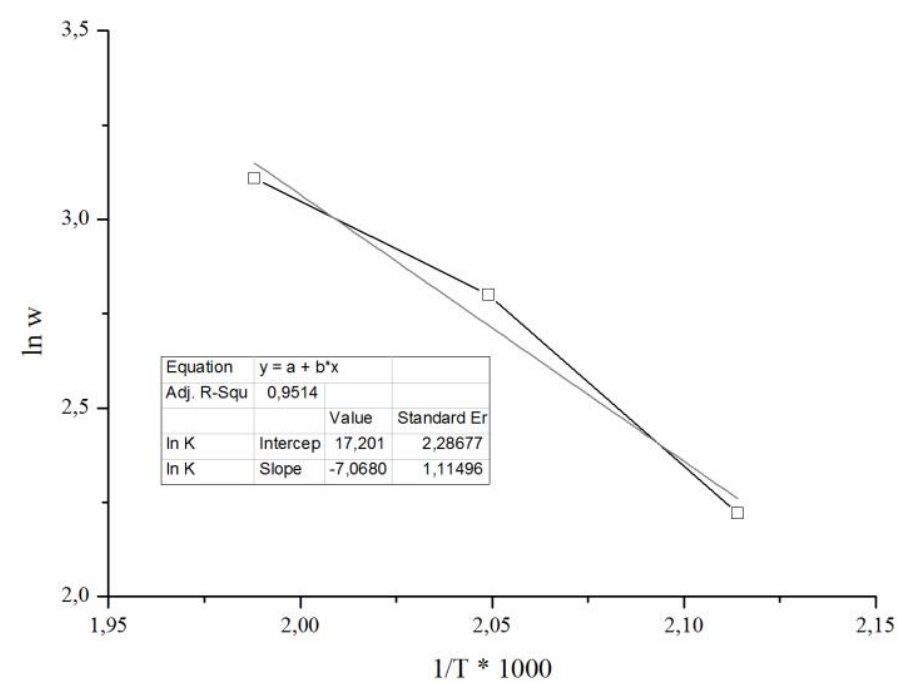

29. ábra DMC bomlás során a DMC fogyás sebességének hömérsékletfüggése $\mathrm{Cu}$ /Norit katalizátoron 
Magasabb hőmérsékleten (488 és 503 K) a konverzió erőteljesen nőtt, a termékösszetétel azonban csak arányaiban változott. A DMC fogyás sebességének hőmérsékletfüggéséből meghatároztuk a bomlás aktiválási energiáját (29. ábra) az Arrhenius egyenlet alapján, amely 58,7 kJ/mol. Ez az érték jóval kisebb, mint a $\mathrm{Cu} / \mathrm{MWCNT}$ katalizátoron hasonló körülmények között kapott 79,6 kJ/mol. Anderson és társai zeolit hordozós réz katalizátoron végzett DMC bontás során $90,4 \mathrm{~kJ} / \mathrm{mol}$ körüli értéket publikáltak, amely mind az MWCNT, mind az általunk bemutatott Norit hordozós réz katalizátoron mértnél magasabb [77]. A Cu/Norit esetében a DMC fogyás sebességének hömérsékletfüggését figyelembe véve a metanol oxidatív karbonilezésénél alkalmazott 393 K-re extrapoláltuk. Kiszámoltuk a DMC szintézis során lezajló DMC bomlás konverzióját $(0,6 \%)$, amelyből arra következethetünk, hogy a szintézis során a bomlás mértéke elhanyagolható.

A

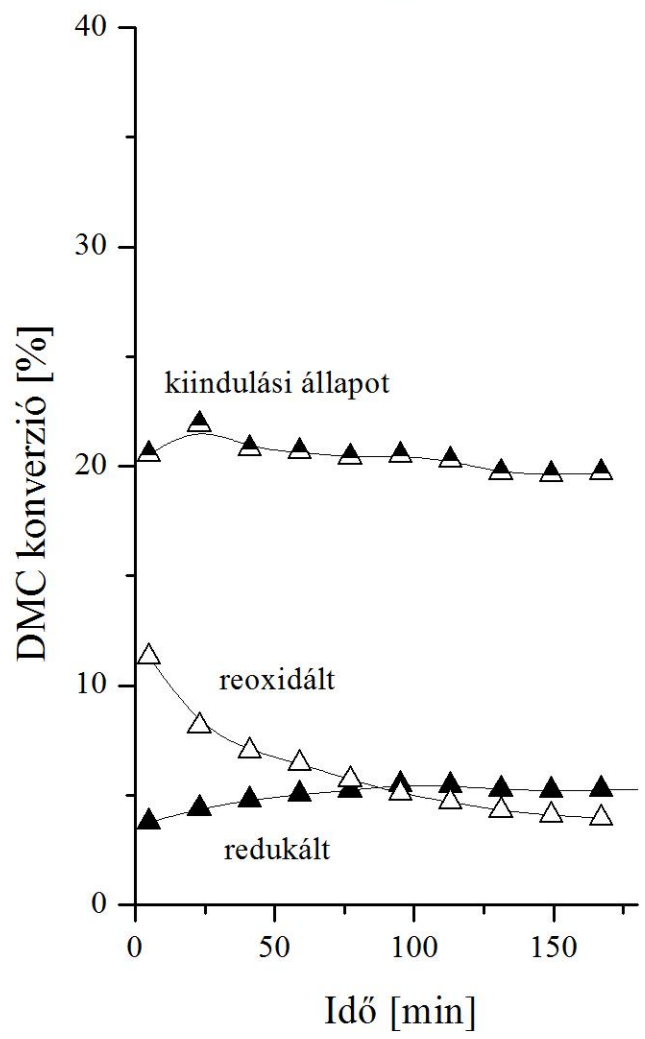

$\mathrm{B}$

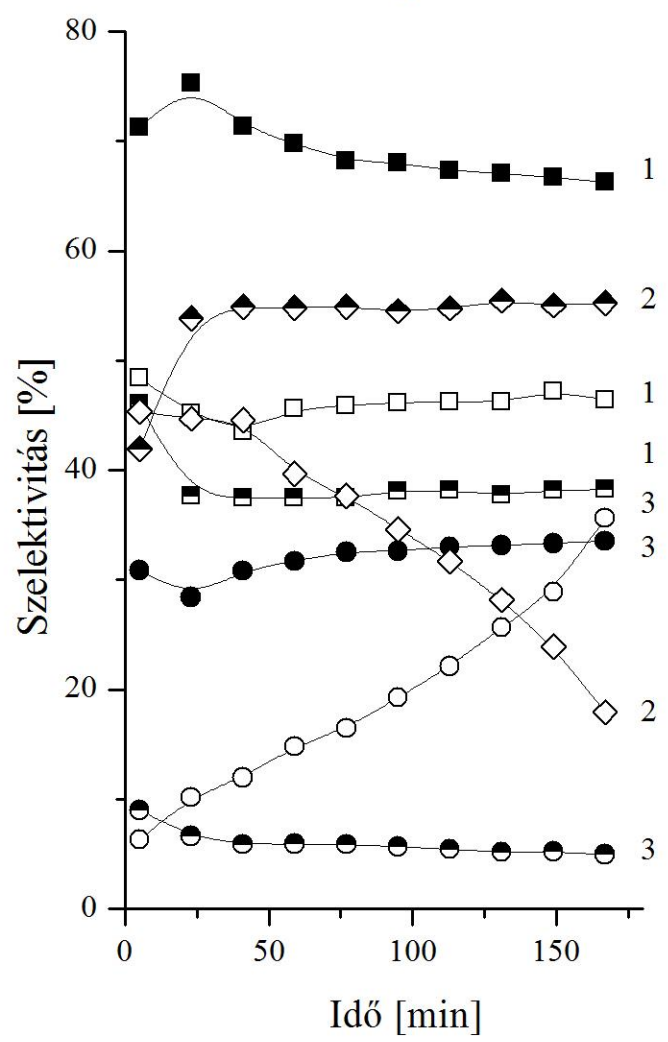


A katalizátor előkezelésének változtatása módosította a DMC reakció mechanizmusát 473 K-en (30. ábra). A Cu/Norit esetében, amikor a korábban leírtak szerint kezeltük elő a mintát, a DMC konverziója viszonylag stabil volt, körülbelül 7\% (28. ábra). Előkezelés nélkül a DMC konverzió sokkal magasabb volt és időben állandó maradt, körülbelül $20 \%$ (30. ábra). Amikor a katalizátort újra oxidáltuk a redukálás után, a DMC konverzió csökkent (12\%-ról 3\%-ra). A különböző előkezelések eredményeként különféleképpen alakultak a termékösszetételek (30. ábra), habár a fö termék továbbra is a DME és a $\mathrm{CO}_{2}$ volt. Amikor a katalizátor elökezelését megváltoztattuk a $\mathrm{Cu}$ /Noriton jelentős mennyiségü metanol keletkezett. A termékek összetétele és aránya is változott. Amikor a redukált mintát vizsgáltuk, $\mathrm{CO}_{2}$ és DME keletkezett. Amikor nem alkalmaztunk előkezelést, metanol és $\mathrm{CO}_{2}$ képződött, valamint kis mennyiségü DME. A termékek szelektivitásának aránya jelentősen megváltozott, amikor újra oxidáltuk a $\mathrm{Cu} /$ Noritot. Bár a $\mathrm{CO}_{2}$ képződés stabil volt időben, a DME szelektivitása nőtt, a metanol szelektivitása csökkent.

A

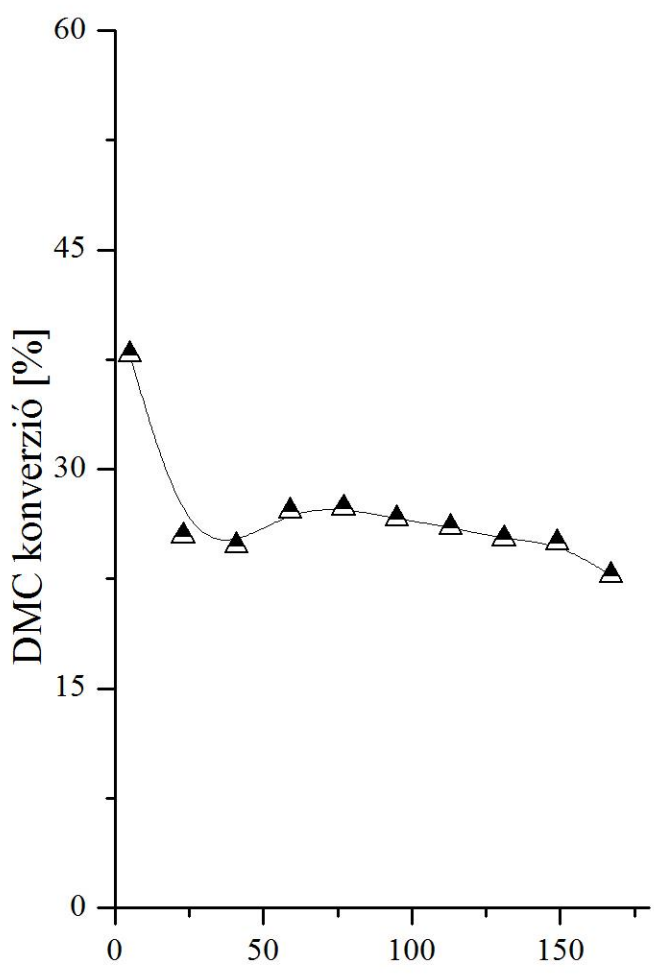

B

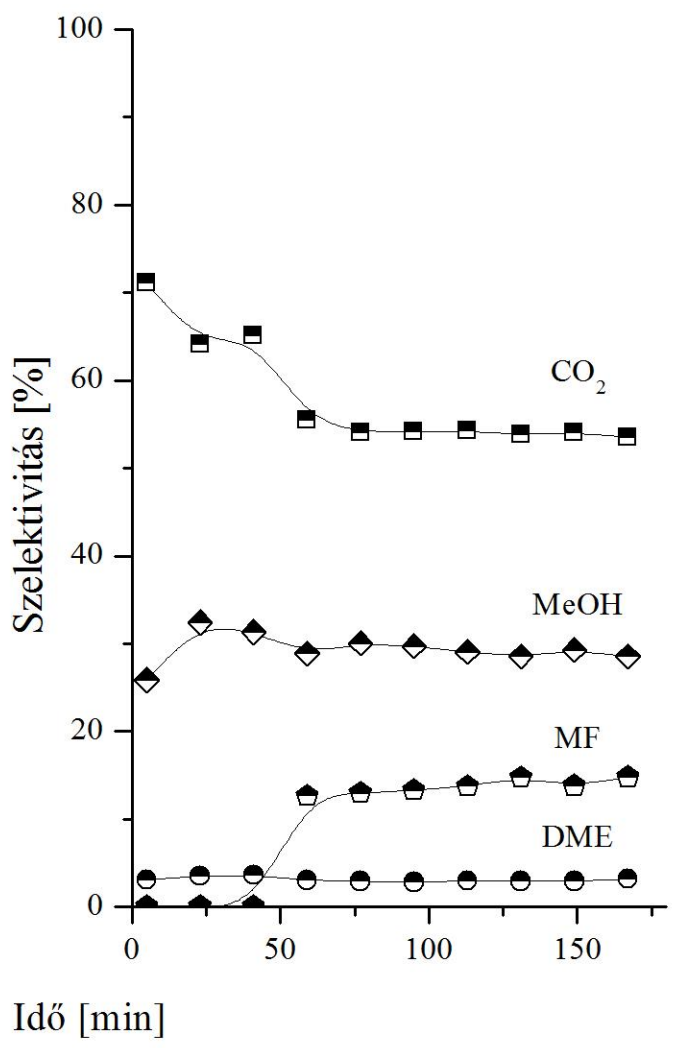


$\mathrm{Az}$ oxidált és redukált réz szerepének megértéséhez tanulmányoztuk az $\mathrm{O}_{2}$ hatását is. Amikor $\mathrm{O}_{2}$ - $\mathrm{t}\left(\mathrm{DMC} / \mathrm{O}_{2} / \mathrm{He}=1 / 2 / 2\right)$ is kevertünk a reakcióelegyhez, a DMC konverzió 473 K-en Cu/Noriton 38\%-ról 22\%-ra csökkent (31. ábra). A közel állandó aktivitású szakaszban a DMC fogyás több mint ötször nagyobb volt $\mathrm{O}_{2}$ jelenlétében, mint a hiányában. Számottevő mennyiségű metanolt és MF-ot detektáltuk a reakció alatt és csak kevés DME-t. A MF képződését másodlagos reakciók lezajlásával magyarázhatjuk, ahol a metanol oxidációjából hangyasav keletkezik, amely metanollal reagál.

Azért, hogy kizárjuk annak a feltételezett lehetőségét, hogy a DMC bomlás első lépésben metanol keletkezik, amely tovább reagálva DME-t képez, a metanol bomlását is tanulmányoztuk $473 \mathrm{~K}$-en $\mathrm{Cu} /$ Norit katalizátoron, hasonlóan a $\mathrm{Cu} / \mathrm{MWCNT}$ katalizátorhoz. A metanol ebben az esetben sem bomlott el, így joggal feltételezhetjük, hogy a DME, amit a DMC bontás során kimutattunk, közvetlenül a reakció során keletkezett.

\subsubsection{XP spektroszkópiás vizsgálatok}
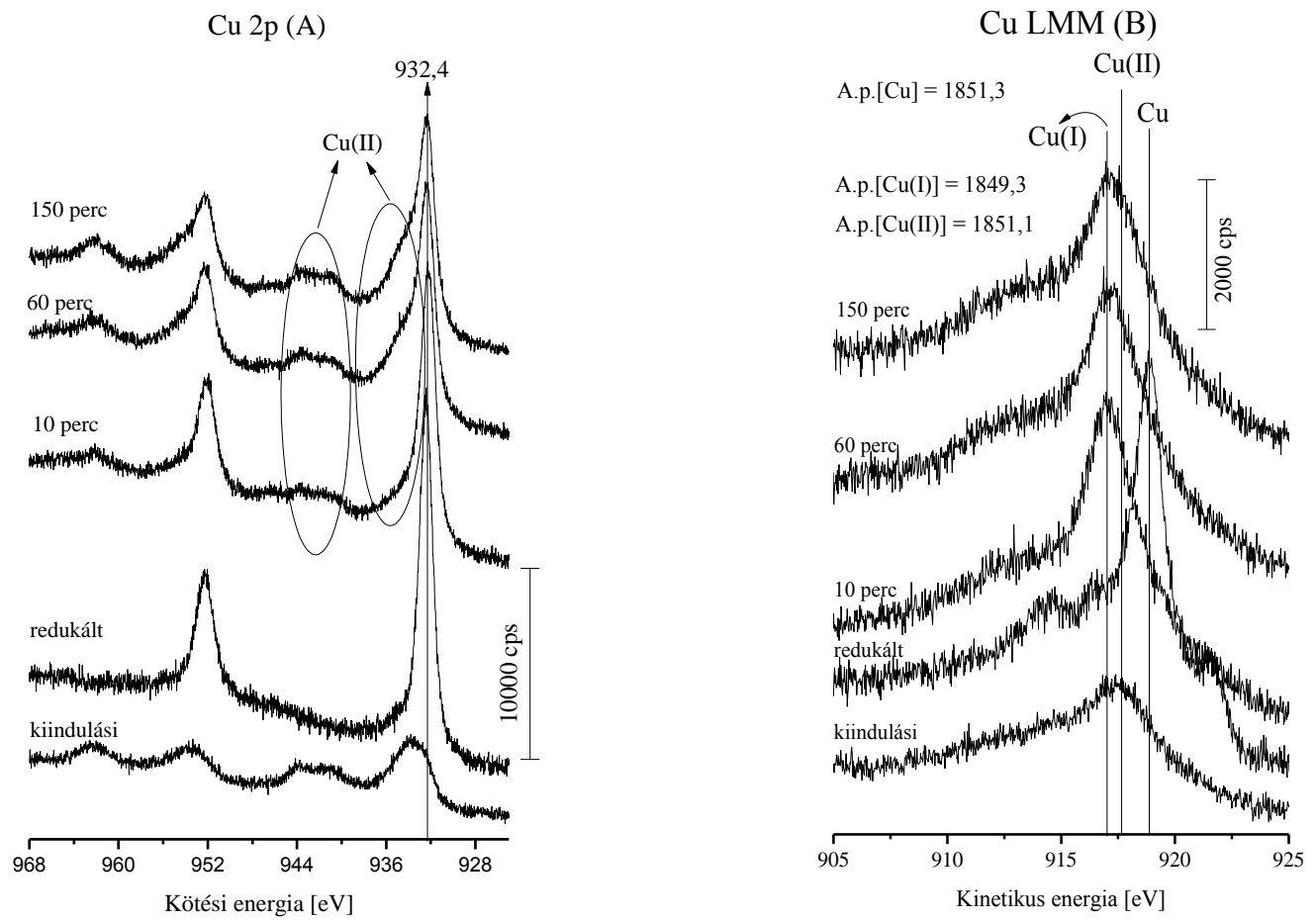

32. ábra Cu 2p XP spektrumok (A) és Cu LMM Auger spektrumok (B) Cu/Norit katalizátoron kiindulási és redukált állapotban valamint $\mathrm{CH}_{3} \mathrm{OH}+\mathrm{CO}+\mathrm{O}_{2}(2: 1: 1)$ reakció 10., 60., 150. percében $393 \mathrm{~K}$-en 
Nagy felbontású XP spektrumokat rögzítettünk $\mathrm{Cu}$ /Norit katalizátor felületén végbemenő változások követésére a $\mathrm{Cu} 2 \mathrm{p}, \mathrm{C} 1 \mathrm{~s}, \mathrm{O} 1 \mathrm{~s}$ és $\mathrm{Cu}$ LMM energia tartományban a kezelés minden szakaszában. A Cu $2 p$ csúcspár $\mathrm{Cu} 2 p_{3 / 2}$-es tagjának helyzete és alakja a kezeletlen mintán 933,6 eV-nál feltehetőleg a nitrát só bomlásából származó $\mathrm{Cu}\left(\mathrm{NO}_{3}\right)_{2}$ és $\mathrm{CuO}$ együttes jelenlétére utal, mint azt a $\mathrm{Cu} / \mathrm{MWCNT}$ esetében már bemutattuk. A csúcs helye a 60 perces redukció után 932,4 eV-ra tolódott és a szatellitek eltüntek (32. ábra). A réz oxidációs állapotainak azonosításához meghatároztuk az Auger paramétert. A $\mathrm{Cu}$ LMM csúcs a redukció után 918,8 eV-nál helyezkedett el, 1851,2 eV-os Auger paramétert adva. Megállapíthatjuk tehát, hogy a réz fémmé redukálódott [81] egyszersmind felületi koncentrációja jelentősen nőtt.

A metanol oxidatív karbonilezése során a $\mathrm{Cu} 2 \mathrm{p}_{3 / 2}$ elektronok kötési energiája és az öket reprezentáló csúcs intenzitása nem változott, de új csúcs alakult ki 944 eV körül. Ez a csúcs megfigyelhető volt már a reakció tízedik perce után is. 60 perccel később erősödő vállakat láttunk a $\mathrm{Cu} 2 \mathrm{p}$ csúcspár mindkét összetevőjének nagy kötési energiájú oldalán. Az Auger-spektrumok inkább a kiindulási állapotban rögzítettre hasonlítottak és nem a redukció utáni spektrumra, mint a $\mathrm{Cu} / \mathrm{MWCNT}$ esetében. Így itt is arra következtethetünk, hogy a réz oxidálódott a reakcióelegyben és jellemzően $\mathrm{Cu}^{+}$formában volt a felületen, némi $\mathrm{Cu}^{2+}$ jelenlétében. Az utóbbi mennyisége nőtt a reakcióidő előrehaladtával, amit bizonyít a réz spektrum intenzívebbé váló szatellit csúcsa és a fotocsúcson kialakuló váll egyaránt.

Hasonló spektrumokat rögzítettünk a $\mathrm{Cu}-\mathrm{Ni} / \mathrm{Norit}$ katalizátor $\mathrm{Cu}$ komponensére. Figyelembe véve a Ni 2p kötési energiáját a kiindulási minta esetében, NiO-ot $(855,6 \mathrm{eV})$ és kis mennyiségü fémes Ni-t $(852,7 \mathrm{eV})$ mutattunk ki, mint ahogy a Cu-Ni/MWCNT-nél is tapasztaltuk. A redukált katalizátor $\mathrm{Ni} 2 \mathrm{p}$ spektruma fémes $\mathrm{Ni}$ és $\mathrm{Ni}^{2+}(852,7$ és 855,6 $\mathrm{eV})$ jelenlétét mutatta, tehát redukálatlan $\mathrm{Ni}$ maradt a $\mathrm{H}_{2}$-es előkezelés után a $\mathrm{Cu}-\mathrm{Ni} / \mathrm{Norit}$ mintán.

A Ni/Norit mintán előkezelés előtt is NiO-ot $(855,6 \mathrm{eV})$ detektáltunk. A redukált mintán egy új szatellitet is megfigyeltünk 854,5 eV-nál a fémes $\mathrm{Ni}(852,7 \mathrm{eV})$ mellett, amely akár eltérő kémiai környezetben létező $\mathrm{Ni}^{2+}$-hoz is rendelhető [86]. 

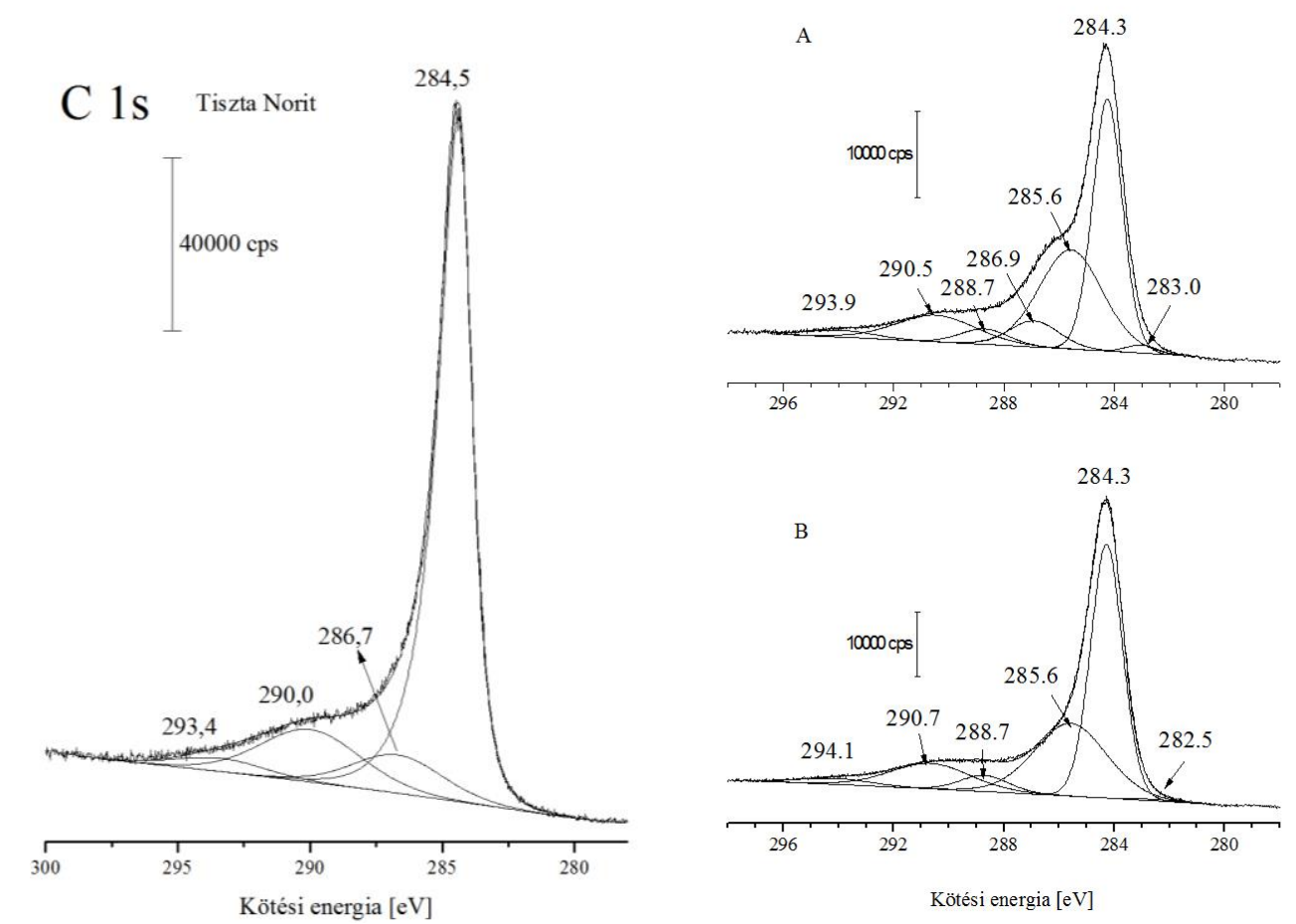

33. ábra $\mathrm{C} 1 \mathrm{~s}$ XP spektrumok tiszta Noriton kiindulási állapotban és $\mathrm{Cu} /$ Noriton kiindulási állapotban (A), és redukálás után $(\mathrm{B})$

Az C 1s régióban rögzített spektrumok nagyon intenzív csúcsot mutattak. Nagy felbontású szénspektrumokat rögzítettünk tiszta Norit és $\mathrm{Cu} /$ Norit katalizátoron, amelyek keskeny aszimmetrikus csúcsot mutattak (FWHM = 1,3-1,4 eV), jellegzetes, hosszú nyúlvánnyal és vállal a nagy kötési energiájú oldalon (33. ábra). A tiszta hordozón egy intenzív csúcs jelent meg 284,5 eV-nál a kiindulási állapotban, $\sim 286,7 \sim 290,0$ és $\sim 293,4 \mathrm{eV}$ komponensekkel, amelyek a $\mathrm{Cu} / \mathrm{MWCNT}$ mintán végzett méréseknél meghatározottakkal megfeleltethetőek.

A redukált $\mathrm{Cu} /$ Norit mintán (33. ábra) egy intenzív csúcsot regisztráltunk 284,3 eV-nál 285,6, 288,7, 290,7 és 294,1 eV komponensekkel, amelyek hasonlóan azonosíthatóak, mint a fent említettek. A felbontott spektrumon egy gyenge komponens is megfigyelhető 282,5 eV-nál, amely karbid jellegü anyag jelenlétére utal [86]. 


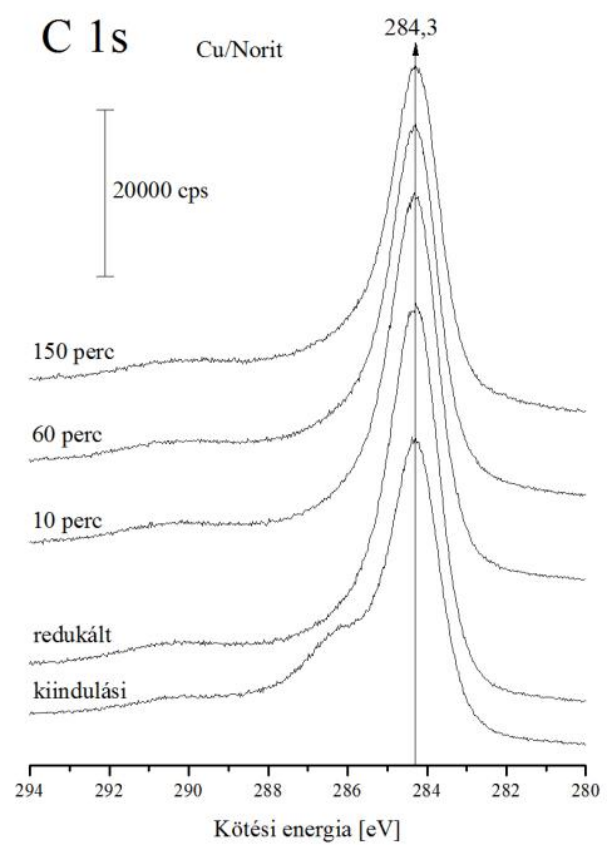

34. ábra $\mathrm{C} 1 \mathrm{~s} X P$ spektrumok $\mathrm{Cu} / \mathrm{Norit}$ katalizátoron $\mathrm{CH}_{3} \mathrm{OH}+\mathrm{CO}+\mathrm{O}_{2}(2: 1: 1)$ reakció során $393 \mathrm{~K}$-en

A kiindulási mintához képest nem tapasztaltunk jelentős változást a $\mathrm{Cu} / \mathrm{Norit}$ hordozó esetében 30 perces $\mathrm{H}_{2}$ áramban történt redukció után valamint a reakció alatt sem. A csúcs alakja és a csúcs alatti területek gyakorlatilag változatlanok maradtak az egész kísérlet során, a különbség 10\%-on belüli volt (33. ábra). A C-O csoportokat képviselő komponens intenzitása azonban jelentősen csökkent. A reakció közben nem tudtunk kimutatni új széntartalmú felületi formák kialakulását. 


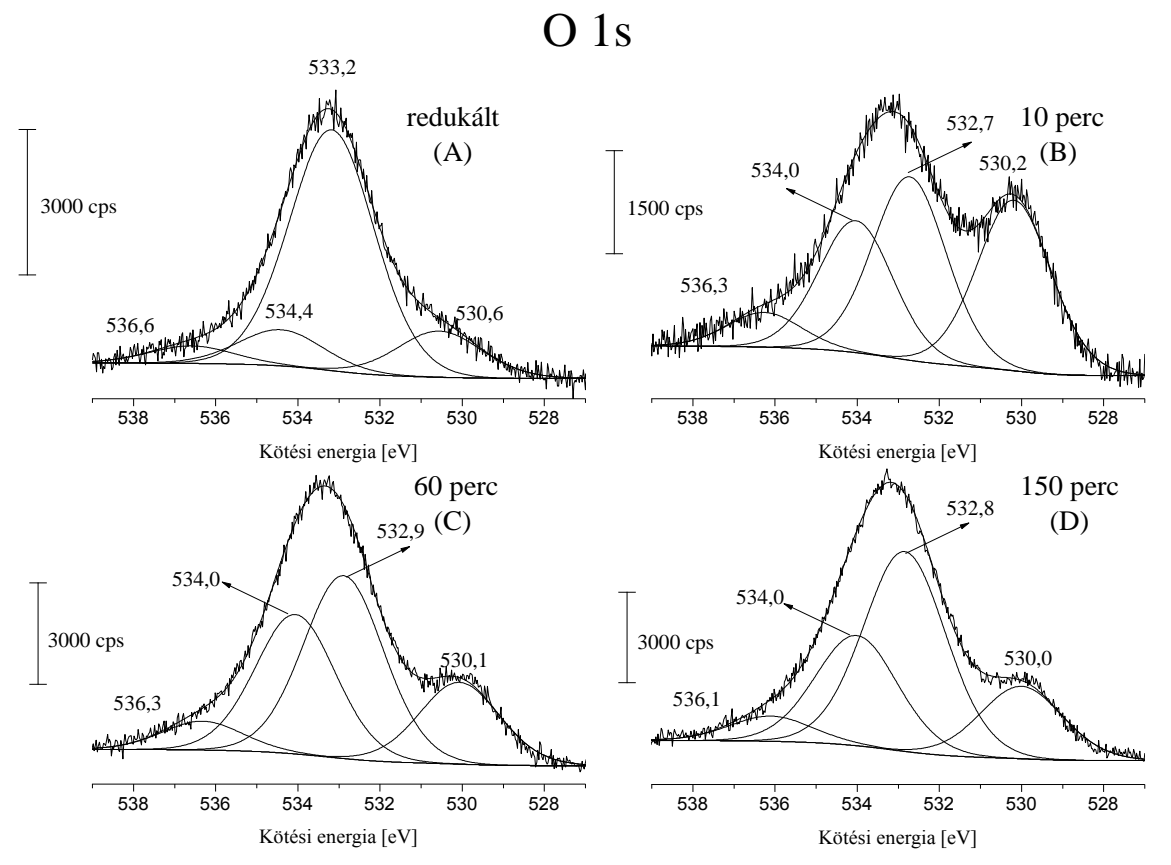

35. ábra $\mathrm{O} 1 \mathrm{~s} X P$ spektrumok $\mathrm{Cu} /$ Norit katalizátoron redukálás után, $\mathrm{CH}_{3} \mathrm{OH}+\mathrm{CO}+\mathrm{O}_{2}(2: 1: 1)$ reakció 10 , 60., 150. percében 393 K-en

Az O 1s régió nehezen látható, különösen a kezelt minták esetében. Azonban a nagy felbontású $\mathrm{O}$ 1s spektrumokból egyértelművé válik, hogy ennek a régiónak igen komplex szerkezete van. Az O 1s tartományban tiszta Norit esetében egy csúcs található $532,5 \mathrm{eV}$ nál, 537,4 eV-nál lévő vállal. A redukálást követően a fő csúcs intenzitása csökkent, de a helyzete nem változott. A kisebb komponens 536,3 eV-ra tolódott és intenzitása növekedett a fő csúcshoz képest (az ábrán nem látható).

A Cu/Norit 60 perces $393 \mathrm{~K}$-es redukálása után is rögzítettük a spektrumokat. Ebben az esetben az $\mathrm{O}$ 1s spektrumra négy komponenst lehet illeszteni, a legintenzívebb 533,2 eVnál található (35. ábra). Ugyanakkor két kisebb vállat lehetett azonosítani 536,6 és 530,6 eV-nál. A csúcsillesztő program feltételezi egy további elem jelenlétét 534,4 eV-nál. A metanol oxidatív karbonilezése után a jel alakja jelentősen megváltozott, egy intenzív csúcs 530,2 eV körül alakult ki 10 perc után, de az intenzitásban nem tapasztaltunk változást. Az oxigén komponensek azonosítása nem egyértelmü az irodalomban. Egyesek szerint [84] [85] [95] az 530-531 eV körüli csúcs a C=O kötés oxigénjéhez rendelhető, amíg Soria-Sánchez és társai ezt a komponenst 531,7 eV-hez rendelték [96]. Minthogy a $\mathrm{C}=\mathrm{O}$ kötések a szénszerkezet szélein különböző csoportokban fordulhatnak elö, mindkét 
feltételezés igaz lehet. A réz-oxigén kötésekből származó elektronok is hozzájárulhatnak ehhez a csúcshoz. Figueiredo és társai szerint [84] a redukció után rögzített 533,2 eV-os csúcs a -O- kötéshez rendelhető. Ez a csúcs eltünt a reakció alatt, azonban új csúcsok jelentek meg 532,7-532,9 eV-nál, amelyek intenzitása növekedett. Ez a komponens például az anhidridek $\mathrm{C}=\mathrm{O}$ kötéseiből eredhet. $\mathrm{A} \mathrm{OH}$ csoportok is hozzájárulhatnak a kialakulásukhoz. Az 534,0-534,4 eV környékén lévő csúcsok származhatnak karboxil csoportokból, amíg az 536,1-536,6 eV-nál lévők adszorbeált víztől. Amint azt már említettük, sem az intenzitásbeli, sem az alakbeli változás nem volt jelentős a C 1s spektrumon a reakció folyamán. Változások ugyan történtek az $\mathrm{O}$ 1s spektrumok szerkezetében, azonban ezek nem tükröződtek a szén spektrum lefutásában. Ennek oka az lehet, hogy redukció után a mintán a szén oxigén arány a felületen körülbelül 20:1 volt. 150 perc eltelte után az oxigéntartalom megduplázódott, mintegy 10\%-ra nőtt, de ez még mindig túl kevés volt ahhoz, hogy látható változásokat okozzon a szén spektrumokon.

A fémek felületi koncentrációját is meghatároztuk az XP spektrumok alapján az előkezelt mintákban. A redukált $\mathrm{Cu} / \mathrm{Noriton}$ a $\mathrm{Cu}$-tartalom 0,8 at.\% volt, a $\mathrm{Cu}-\mathrm{Ni} / \mathrm{Noriton} 2$ at.\% $\mathrm{Cu}$ és 4,8 at.\% Ni kimutatható. A Ni/Norit felszínén a fémtartalom 6,2 at.\% volt.

\subsubsection{Infravörös spektroszkópiás vizsgálatok}

A metanol oxidatív karbonilezése során a Cu/Noriton DRIFT cellában 393 K-en rögzített infravörös spektrumok föképp a gázfázisú CO és metanol sávjait mutatták. Háttérnek a tiszta Noriton megegyező kinetikai paraméterek mellett rögzített spektrumokat tekintettük, amelyeket az egyes kezelési szakaszokban felvett spektrumokból levontunk. A 2200-1000 $\mathrm{cm}^{-1}$ tartományban 2141, 1767, 1610, 1459, 1404, 1293-1291, 1068-1053, 1036-1034 és 1026-1021 cm $\mathrm{cm}^{-1}$-nél találtunk elnyelést. Ezek intenzitása különböző módon változott időben. Az $2141 \mathrm{~cm}^{-1}$-nél mért abszorpció csökkent, az 1767 és $1292 \mathrm{~cm}^{-1}$-nél lévő sávok felerősödtek az idő előrehaladtával. Az 1404, 1034 és $1021 \mathrm{~cm}^{-1}$-nél lévő sávok intenzitása először megnőtt, de a reakció 30. perce után csökkenni kezdett (36. ábra). 


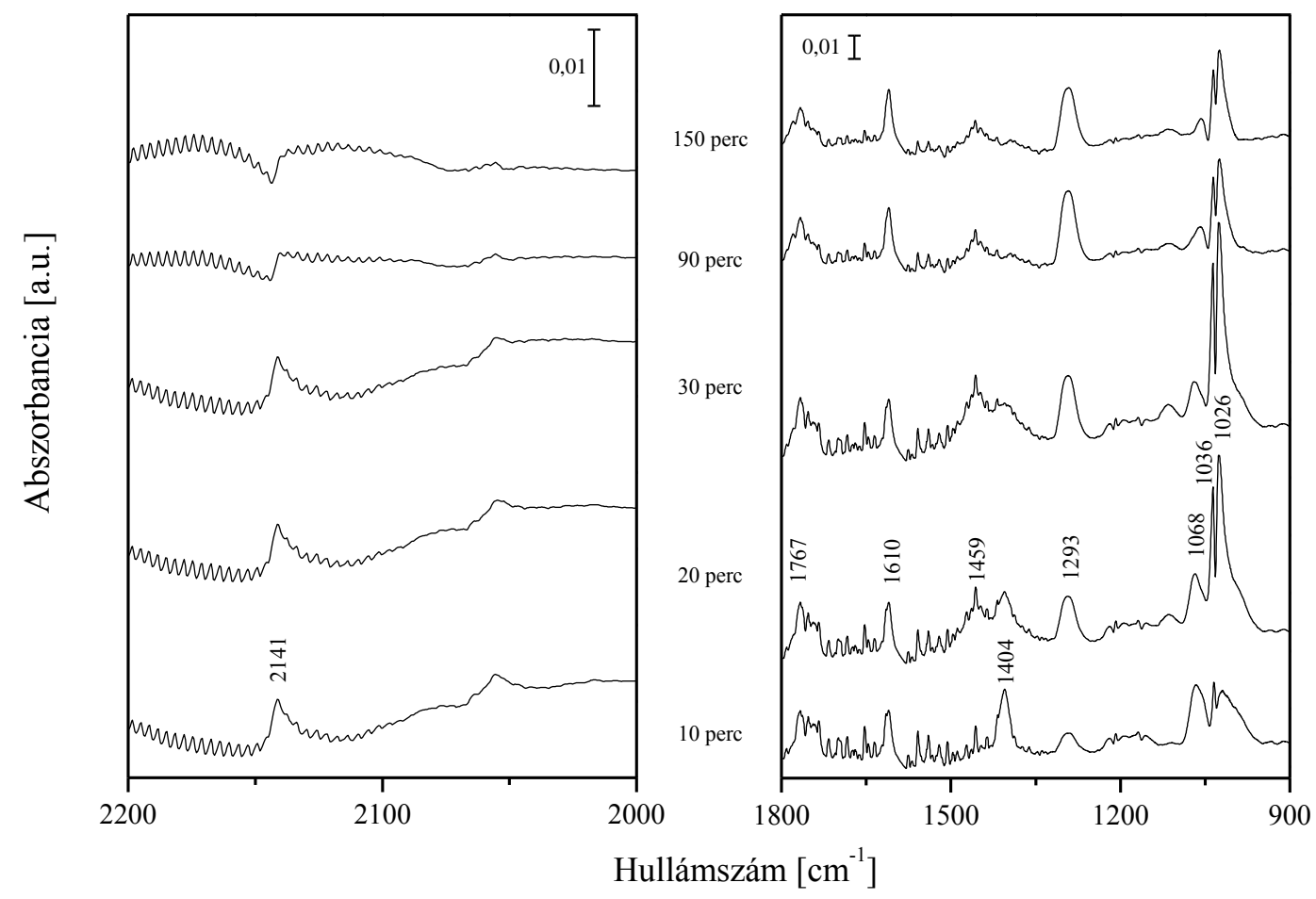

36. ábra IR spektrumok $\mathrm{Cu} /$ Norit katalizátoron $\mathrm{CH}_{3} \mathrm{OH}+\mathrm{CO}+\mathrm{O}_{2}(2: 1: 1)$ reakció 10., 20., 30., 90. és 150. percében 393 K-en

A $2141 \mathrm{~cm}^{-1}$-nél mért elnyelés a CO régióhoz köthető. Irodalmi adatok szerint a CO adszorpciója $\mathrm{Cu}^{2+}$-on vagy fém $\mathrm{Cu}$-en túlnyomó részben gyenge és reverzibilis $300 \mathrm{~K}$ felett, a CO legerősebben a $\mathrm{Cu}^{+}$-hoz kötött [97] [98]. London és Bell [99] egy éles sávot talált $2140 \mathrm{~cm}^{-1}$-nél a $\mathrm{CO}$ adszorpció során CuO-on. Engeldinger és társai [98] egy jellegzetes $\mathrm{Cu}(\mathrm{I})-\mathrm{CO}$ sávot figyeltek meg a Cu tartalomtól függően $2060-2146 \mathrm{~cm}^{-1}$ között $\mathrm{Cu}$ Y zeolit katalizátoron. XPS méréseink igazolják, hogy a $\mathrm{Cu}^{+}$és $\mathrm{Cu}^{2+}$ is megjelenik a katalizátor felületén. Eredményeink szerint a $2141 \mathrm{~cm}^{-1}$-nél lévő abszorpció intenzitása időben csökkent a reakció elörehaladtával, az XP spektrumok szerint a $\mathrm{Cu}^{2+}$ mennyisége nőtt a felületen, amiből arra következtetünk, hogy a $2141 \mathrm{~cm}^{-1}$-nél megfigyelt forma inkábba $\mathrm{Cu}^{+}$-hoz, mint a $\mathrm{Cu}^{2+}$-hoz kötött $\mathrm{CO}$ abszorpciójának felel meg.

Annak érdekében, hogy a reakció közben $2000 \mathrm{~cm}^{-1}$ alatt detektált sávokat azonosíthassuk, a $\mathrm{Cu}$ /Norit katalizátoron keletkező fö termékek infravörös spektrumát is rögzítettük. A DMC szobahőmérsékleti adszorpciója után a 2000-1100 cm közötti régióban: 1781,1768 , 1462, 1454, $1293 \mathrm{~cm}^{-1}$-nél figyeltünk meg sávokat. Hasonló spektrumokat rögzítettünk a többfalú szén nanocső hordozós Cu minta esetében is (15. ábra). Az 1781, 1768 és 1293 
$\mathrm{cm}^{-1}$-nél lévő sávokat már korábban, a $\mathrm{Cu} / \mathrm{MWCNT}$ mintán végzett hasonló kísérletek során a DMC-hoz rendeltük. Ez alapján feltételezhetjük, hogy a katalizátoron DMC is jelen van. A Cu/Noriton adszorbeáltatott MF spektruma a 2000 és $1100 \mathrm{~cm}^{-1}$ közötti régióban 1768, 1754 és $1743 \mathrm{~cm}^{-1}$-nél mutatott abszorpciós sávokat, valamint gyenge abszorpciót figyeltünk meg $1208 \mathrm{~cm}^{-1}$-nél. A fentiek egyezést mutatnak a Cu/MWCNT mintán kapott eredményekkel.

A reakció elején 1459 és $1404 \mathrm{~cm}^{-1}$-nél észlelt formák a C-H deformációs régióba esnek, amelyek a DMM $\mathrm{CH}_{3}$ és $\mathrm{CH}_{2}$ csoportjainak aszimmetrikus rezgéseitől eredhetnek [100].

Az $1610 \mathrm{~cm}^{-1}$-es sáv adszorbeált vízre utal.

A $\mathrm{CH}_{3} \mathrm{OH}$ és a $\mathrm{Cu}$ kölcsönhatásából származó változások az $1100 \mathrm{~cm}^{-1}$ alatti régióban jelennek meg. Kimutatták, hogy a metanol tiszta $\mathrm{Cu}$ felülettel csak gyengén lép kölcsönhatásba. Oxidált felületen, 20\%-os oxigén borítottság esetén érhető el a maximális mértékü metanol adszorpció [101]. A metanol disszociatívan adszorbeálódik $\mathrm{Cu}^{+}$-on, metoxi csoportok képződésével [98]. Ezek az eredmények arra utalnak, hogy a metanol és a CO aktiválása is a $\mathrm{Cu}^{+}$-on történik. A metanol adszorpciója $\mathrm{Cu}_{2} \mathrm{O}$-on 1064 és $1030 \mathrm{~cm}^{-1}$ nél mutat elnyelési sávokat, amelyeket a metoxi $\mathrm{C}-\mathrm{O}$ vegyérték rezgése és a $\mathrm{CH}_{3}$ kaszáló rezgéseinek tulajdonítanak [102]. A fentiek alapján 1068 és $1036 \mathrm{~cm}^{-1}$-nél megfigyelt sávok az oxidált $\mathrm{Cu}-$ hez kötött metoxi $\mathrm{C}-\mathrm{O}$ vegyérték rezgéseihez és $\mathrm{CH}_{3}$ kaszáló rezgéseihez rendelhetők. A metoxi, amelyben a $\mathrm{C}-\mathrm{O}$ a felületre merőlegesen áll, a $\mathrm{Cu}(100)$ felületen az irodalmi adatok szerint $984 \mathrm{~cm}^{-1}$-nél abszorbeál $210 \mathrm{~K}$-en [103]. A 1021-1026 $\mathrm{cm}^{-1}$-nél megfigyelt sáv egy ettől eltérő szerkezetü $\mathrm{CH}_{3}-\mathrm{O}$ C-O vegyérték rezgésének tudható be. 


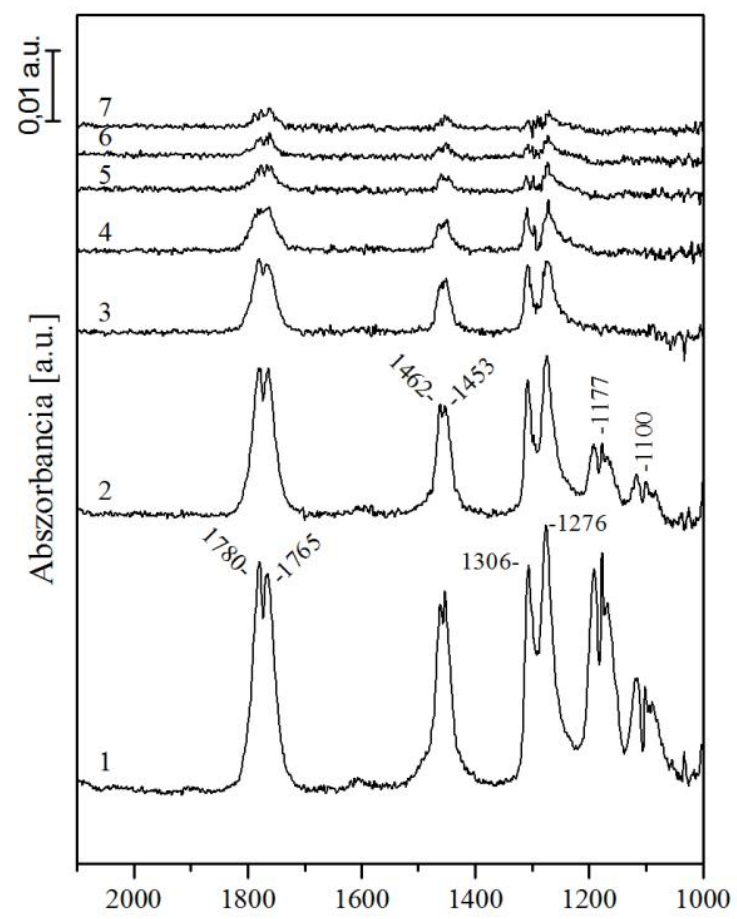

37. ábra $\mathrm{Cu} /$ Norit katalizátoron DMC bontás során $503 \mathrm{~K}$-en rögzített különbségi IR spektrumok, amelyeket az őket megelőzőekből kivontuk(10-5 $\min (1), 20-10 \min (2), 30-20 \min (3), 60-50 \min$ (4) 90-80 min (5),

\section{0-110 $\min (6), 180-170 \min (7))$}

A DMC bontás során $\mathrm{Cu} /$ Noriton $503 \mathrm{~K}$-en rögzített infravörös spektrumok föleg a gázfázisú DMC jellemzőit mutatták. A 2000-1100 cm-1 közötti régióban 1780, 1765, 1462, 1453, 1306, 1276, 1177, $1100 \mathrm{~cm}^{-1}$-nél figyeltünk meg abszorpciós sávokat, amelyek intenzitása csökkent az idő előrehaladtával. 30 perc elteltével a spektrumok már alig változtak tovább (37. ábra). Figyelembe véve a DMC adszorpció után rögzített abszorpciós sávokat arra következtettünk, hogy a reakció elején a megkötött DMC mennyisége nőtt. Az 1780, 1765, 1462, 1453 és $1306 \mathrm{~cm}^{-1}$ sávok a korábbiakban leírtak alapján a $\mathrm{DMC} v(\mathrm{C}=\mathrm{O})$ valamint a cisz-transz és cisz-cisz szerkezetü $\delta_{\mathrm{as}}\left(-\mathrm{CH}_{3}\right)$ rezgésekhez rendelhetőek. Az 1177 és $1100 \mathrm{~cm}^{-1}$-nél detektált sávok a DME $\rho\left(\mathrm{CH}_{3}\right)$ és $v_{\mathrm{a}}(\mathrm{COC})$ rezgései. 


\subsubsection{DMC TPD}

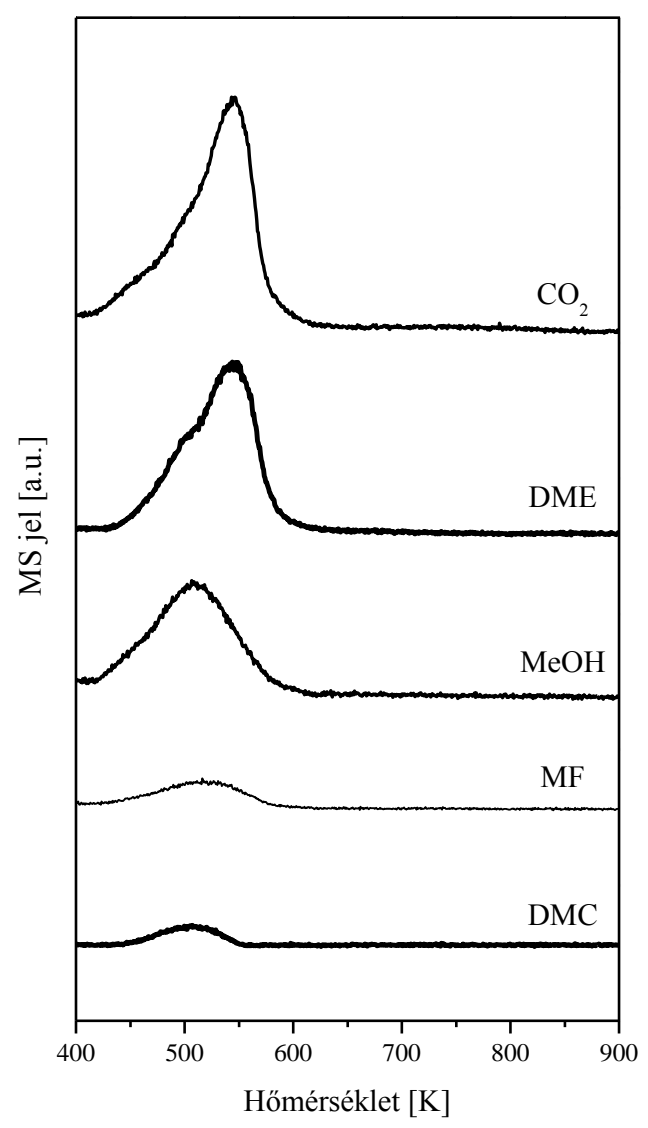

38. ábra Szobahőmérsékleten adszorbeáltatott DMC TPD spektrumok $\mathrm{Cu} /$ Norit katalizátoron

A DMC hőmérséklet programozott deszorpcióját áramlásos rendszerben $\mathrm{Cu} / \mathrm{Norit}$ katalizátorra 323 K-en történt adszorpció után tanulmányoztuk. Az adszorbeált DMC mennyisége $(165 \mathrm{mg} / \mathrm{g})$ folyamatosan nőtt az idő előrehaladtával, még 60 perc után sem érte el a telítettségi értéket. Ezután a reaktort He-mal 30 percig öblítettük, a mintát $\mathrm{He}$ áramban felfütöttük és a deszorbeált gázokat tömegspektrométerrel elemeztük.

A felfütés során $415 \mathrm{~K}$ felett $\mathrm{CH}_{3} \mathrm{OH}(\mathrm{m} / \mathrm{e}=31,32,15), \mathrm{CO}_{2}(\mathrm{~m} / \mathrm{e}=44)$ és $\mathrm{DME}(\mathrm{m} / \mathrm{e}=45$, 46) deszorpciót figyeltünk meg. A MF $(\mathrm{m} / \mathrm{e}=30)$ és a $\mathrm{DMC}(\mathrm{m} / \mathrm{e}=59)$ deszorpció is kimutatható közel ugyanabban a hőmérséklet-tartományban (38. ábra). A szén-monoxid $(\mathrm{m} / \mathrm{e}=28)$ képződés nem volt egyértelmü, az m/e=28 fragment több termékre is jellemző, a bizonytalanság túl nagy. $\mathrm{A} \mathrm{CO}_{2}$ és DME deszorpciós csúcs maximumai $550 \mathrm{~K}$-nél voltak. Ez az érték körülbelül 40 fokkal magasabb, mint a metanol és a DMC esetében (38. ábra). Nem lehet kizárni a $\mathrm{CH}_{4}$ képződését sem, de a keletkezett mennyiség sokkal kisebb, mint a többi terméké. Az eredmények arra utalnak, hogy két különböző DMC adszorpciós hely 
létezik a katalizátor felületén. Mindkét helyen reverzibilisen kötődik meg a DMC. Deszorbeálódhat mélyebb rétegekböl, vagy a bomlás során keletkező termékekből rekombinálódhat.

\subsection{6 $\mathrm{NH}_{3}$ és $\mathrm{CO}_{2} \mathrm{TPD}$}

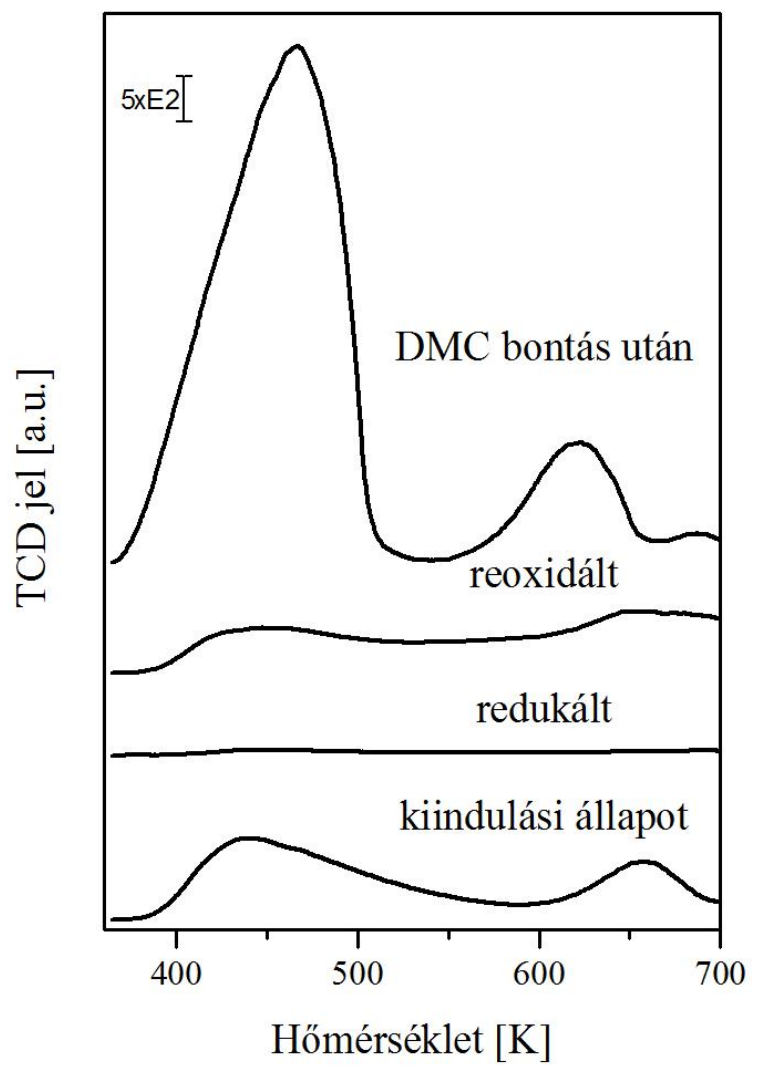

39. ábra $\mathrm{NH}_{3} \mathrm{TPD} \mathrm{Cu}$ /Norit katalizátoron különböző előkezelések valamint DMC bontás után

A $\mathrm{Cu}$ /Norit katalizátoron rögzített $\mathrm{NH}_{3}$ TPD görbe kétféle savas hely létezését mutatta a felületen kiindulási állapotban, amelyek szinte teljesen eltűntek a redukció hatására. Újra oxidálva a mintát a gyengén savas jelleg újra megjelent. A reakció után jelentősen nőtt a deszorbeált $\mathrm{NH}_{3}$ mennyisége, de a saverősségre jellemző TPD csúcs maximumok nem változtak lényegesen (39. ábra).

Amikor az $\mathrm{NH}_{3}$ TPD során kapott csúcs alatti területeket hasonítottuk össze, amelyek arányosak a savas centrumok számával, a redukált Cu/MWCNT (19. ábra) és Cu/Norit (39. ábra) minták esetében, a deszorbeált $\mathrm{NH}_{3}$ mennyisége nem volt sokkal nagyobb a $\mathrm{Cu} / \mathrm{Norit}$ esetében, mint a $\mathrm{Cu} / \mathrm{MWCNT}$ mintán. Ismeretes, hogy a karboxil-, fenol, laktol és lakton csoportok felelősek a $\mathrm{CuCl} / \mathrm{AC}$ savas tulajdonságaiért, amelyet $\mathrm{NH}_{3}$ TPD-val támasztottak 
alá [64] [35]. Megállapították, hogy a savas helyek száma befolyásolja a savas tulajdonságot, mennyisége pedig csökken a kalcinálási hőmérséklet növelésével. A gyengébben savas helyek gyorsabban tüntnek el kalcinálással [64]. Eredményeink alátámasztják ezt az állítást, miszerint a savas helyek száma drasztikusan csökkent a minták előkezelése alatt 873 K-en.

Az eredmények alátámasztják az XPS mérések esetében tett megfigyeléseket. A savas helyek kimutathatóak voltak a felületen a kiindulási állapotban. A redukció után nem voltak detektálhatóak, végül a reakció alatt folyamatosan erősödtek. Ahogy azt az előbbiekben leírtuk, a redukció hatására a felületi oxigén tartalmú formák mennyisége jelentősen csökkent (35. ábra).

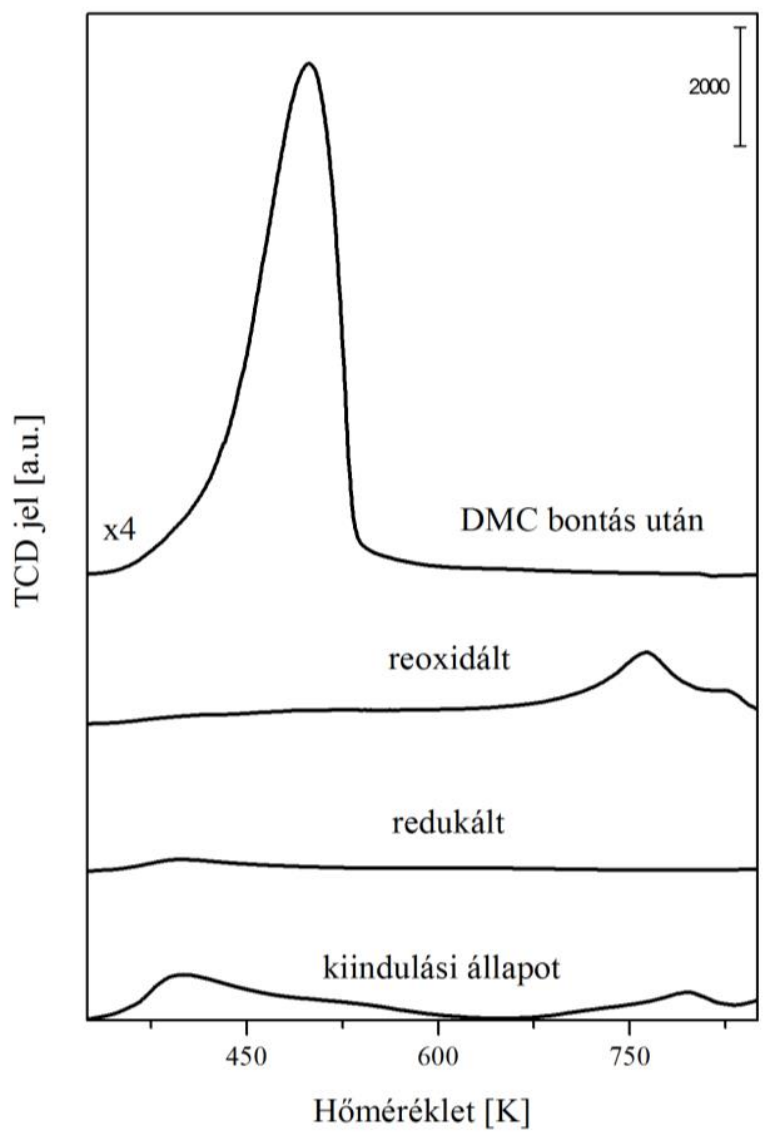

40. ábra $\mathrm{CO}_{2} \mathrm{TPD} \mathrm{Cu} /$ Norit katalizátoron különböző előkezelések után valamint DMC bontás után

A $\mathrm{CO}_{2}$ TPD görbék a kezeletlen $\mathrm{Cu} /$ Norit esetében 400 és $795 \mathrm{~K}$ körül mutattak deszorpciós csúcsot, amelyek a felületi bázikus helyekre jellemzőek. Redukció hatására szinte teljesen eltünt az alacsony hőmérsékletű TPD csúcs, de $762 \mathrm{~K}$ körül egy új forma alakult ki a reoxidált felületen. A DMC bontás után rögzített spektrumon egy nagyon 
intenzív TPD csúcsot regisztráltunk $\left(\mathrm{T}_{\max }=497 \mathrm{~K}\right)$, amely nagyszámú bázikus centrum kialakulását jelenti (40. ábra).

$\mathrm{CeO}_{2}$ hordozós katalizátorok felületi sav-bázis tulajdonságait vizsgálták $\mathrm{NH}_{3}$ és $\mathrm{CO}_{2}$ adszorpcióval. A katalizátorok savas és a bázikus helyeinek összmennyiségbeli növekedését a hordozóval hozták összefüggésbe, és hangsúlyozták a morfológiai elváltozások okozta különbségeket. Megállapították, hogy a nagy mennyiségü savas és a bázikus hely és azok erőssége pozitív hatást gyakorol a katalitikus teljesítményre [104].

A alumínium-szilikát nanocső hordozós Ni és $\mathrm{Cu}$ katalizátorok esetében meghatározták, hogy a fém felelős a bázikus helyekért, amíg a hordozón savas helyek voltak. A mérések szerint a sav-bázis egyensúly erősen befolyásolta a DMC szintézist [105]. 


\section{Eredmények kiértékelése}

A dimetil-karbonát szintézis részletes, a termékek képződését helyesen leíró mechanizmusa, nehezen feltárható. Ennek ellenére sok következtetés levonható a dolgozatban leírtak alapján.

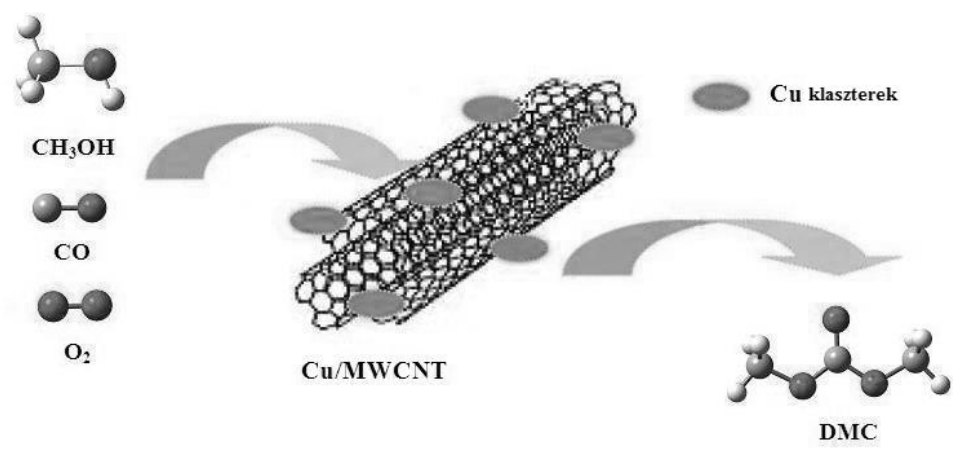

41. ábra A DMC kialakulásának sematikus ábrázolása $\mathrm{Cu} / \mathrm{MWCNT}$ katalizátoron

Eredményeink szerint a metanol oxidatív karbonilezésében a szén hordozós $\mathrm{Cu}$ katalizátorok aktívak voltak. A kétfémes katalizátorok használatakor a DMC kitermelés jelentősen kisebb volt, míg a Ni katalizátorok esetében DMC alig keletkezett.

A $\mathrm{Cu} / \mathrm{MWCNT}$ mintán a reakció állandó aktivitású szakaszában a metanol konverzió 4\% volt (1. ábra). A DMC képződési sebessége növekedett a reakció első szakaszában, majd enyhén csökkenni kezdett (3. ábra).

A Cu/Norit figyelemre méltó aktivitást mutatott a metanol oxidatív karbonilezése során. A metanol konverzió 35\% volt a reakció állandó aktivitású szakaszában, a CO konverzió a metanol konverzióval együtt változott (21. ábra). $\mathrm{A} \mathrm{CO}_{2}$ képződési sebessége először növekedett, majd csökkent, végül közel állandó maradt. A MF képződési sebessége 100 perc után maradt szinte teljesen azonos. A DMC képződése csak egy 100 perces indukciós periódus után kezdődött, majd hirtelen megindult a képződése és elérte a közel állandó aktivitású szakaszt (22. ábra).

A katalizátor eltérő előkezelése különböző hatását gyakorolt a DMC szintézisére a $\mathrm{Cu}$ /Norit esetében. Az alacsonyabb hőmérsékletű redukálás a DMC képződés indukciós idejét elnyújtotta és a DMC szelektivitás az állandó aktivitású szakaszban kisebb volt. Elökezelés nélkül a katalizátor teljesen inaktív volt a DMC szintézisben. Amikor az 
előkezelés után a katalizátort a reakció előtt oxidáltuk, a DMC képződés indukciós ideje enyhén csökkent (24. ábra).

A reakció hőmérséklet változtatása eltérő termékeloszlást eredményezett a DMC szintézisében $\mathrm{Cu} /$ Norit katalizátor használatakor. A $\mathrm{CO}_{2}$ képződési sebessége folyamatosan emelkedett a hőmérséklet függvényében, de a MF és a DMC képződési sebesség görbéinek 383 illetve 393 K-nél maximuma volt (25. ábra). Megállapítottuk, hogy a DMC szintézis optimális reakcióhőmérséklete 393 K.

$\mathrm{Cu} /$ Norit katalizátor alkalmazásakor a térsebesség változtatása eltérö hatást gyakorolt a termékeloszlásra a metanol oxidatív karbonilezése során. A DMC és a $\mathrm{CO}_{2}$ képződési sebessége közel lineárisan nőtt a kontaktidő növelésével. Ezzel szemben a MF képződési sebessége maximum görbe szerint változott (26. ábra).

Bian és munkatársai [28] megállapították, hogy az MWCNT hordozós Cu-Ni kétfémes katalizátorok aktívak DMC direkt szintézisében 393 K-en. Tapasztalataik szerint a DMC hozam 0,4 MPa nyomáson és $393 \mathrm{~K}$-en 0,9\% volt, ami a nyomás csökkentésével együtt csökkent. Az általunk végzett kísérletek során a DMC hozam körülbelül 2,1\% volt $\mathrm{Cu}$ Ni/MWCNT mintán atmoszferikus nyomáson a reakció elején. Ez az érték azonban folyamatosan csökkent a reakcióidővel. Négy óra után a DMC hozam már csak 0,99\% volt. Cu/MWCNT esetében az állandó aktivitású szakaszban a DMC kitermelés körülbelül 1,2\% volt. Mindkét érték magasabb, mint a közölt irodalmi adatok DMC szintézis során 0,4 MPa nyomáson $\mathrm{Cu}-\mathrm{Ni} / \mathrm{MWCNT}$ katalizátoron [28].

Az általunk végzett kísérletek közül a DMC kitermelés $\mathrm{Cu} /$ Noriton volt a legmagasabb az állandó aktivitású szakaszban $(13,2 \%)$ atmoszferikus nyomáson. Hasonló eredményeket az irodalomban leginkább nagy nyomáson tankreaktorokban végzett kísérletek során kaptak. $\mathrm{Cu} \mathrm{Y}$ zeoliton 13,1\%-os [49], $\mathrm{AC}$ hordozós $\mathrm{CuCl}_{2}$ katalizátoron 16,3\%-os [67] DMC kitermelést értek el 2,3 bar nyomáson autoklávban.

\begin{tabular}{|c|c|c|c|c|}
\hline \multirow{2}{*}{ Katalizátor } & \multicolumn{2}{|c|}{ Felületi fémtartalom } & \multirow{2}{*}{$\begin{array}{l}\text { BET } \\
\text { felület }\end{array}$} & \multirow{2}{*}{$\begin{array}{c}\text { DMC hozam } \\
\text { (DMC szintézis során) }\end{array}$} \\
\hline & $\mathrm{Cu}$ & $\mathbf{N i}$ & & \\
\hline & \multicolumn{2}{|c|}{ [atom\%] } & {$\left[\mathrm{m}^{2} / \mathrm{g}\right]$} & {$[\%]$} \\
\hline$C u-N i / M W C N T$ & 0,5 & 1 & 241 & 0,93 \\
\hline Cu/MWCNT & 0,3 & - & 235 & 1,2 \\
\hline $\mathrm{Cu}-\mathrm{Ni} / \mathrm{Norit}$ & 2 & 4,8 & 951 & 0,99 \\
\hline Cu/Norit & 0,8 & - & 1070 & 13,2 \\
\hline
\end{tabular}

3. táblázat A felületi fémtartalom az XPS mérések, BET felület, DMC hozam- katalitikus mérések alapján 
A DMC bontása során a $\mathrm{Cu} / \mathrm{MWCNT}$ és a $\mathrm{Cu} /$ Norit aktivitása különböző volt. A $\mathrm{Cu} / \mathrm{MWCNT}$ már sokkal alacsonyabb hőmérsékleten aktív volt, mint a $\mathrm{Cu} / \mathrm{Norit}$ (5. ábra, 27. ábra). Izoterm körülmények között, alacsony hőmérsékleten (473 K) mindkét katalizátoron $\mathrm{CO}_{2}$ és DME keletkezett. Eredményeink szerint, a termékek szelektivitásának arányai által is alátámasztott, feltételezett reakcióút a következő:

$$
\mathrm{CO}\left(\mathrm{CH}_{3} \mathrm{O}\right)_{2} \leftrightharpoons \mathrm{CO}_{2}+\left(\mathrm{CH}_{3}\right)_{2} \mathrm{O}
$$

A DMC izoterm bontása során a Cu/MWCNT mintán a DMC aktiválási energiája 79,6 $\mathrm{kJ} / \mathrm{mol}$, a Cu/Noriton pedig $58,7 \mathrm{~kJ} / \mathrm{mol}$ volt. Anderson és munkatársai zeolit hordozós réz katalizátoron végzett DMC bontás során $90,3 \mathrm{~kJ} / \mathrm{mol}$ körüli értéket publikáltak, amely mind az MWCNT, mind a Norit hordozós, általunk bemutatott réz katalizátorokon kapott értéknél magasabb [77]. A DMC bontás során számolt aktiválási energiákat figyelembe véve a metanol oxidatív karbonilezésénél használt reakció hőmérsékletre (393 K) kiszámoltuk a DMC szintézis során lezajlódó DMC bomlás konverzióját. Megállapítottuk, hogy a szintézis során a bomlás mértéke nem számottevő.

Annak ellenére, hogy a savas helyek száma és a BET felület (2. táblázat) a Norit hordozó esetében volt a nagyobb, mégis a $\mathrm{Cu} / \mathrm{MWCNT}$ bizonyult aktívabbnak a DMC bontásban. Az újra oxidált mintán magasabb konverziót értünk el, mint a redukált katalizátoron. A $\mathrm{Cu} /$ Norit esetében a termékösszetétel is megváltozott. A redukált mintán föként DME, míg a reoxidált mintán jellemzően metanol keletkezett (30. ábra). Külön kísérletben kimutattuk, hogy a metanol, az izoterm DMC bontásnál alkalmazott reakciókörülmények között, nem bomlik el. Eredményeinket összegezve megállapíthatjuk, hogy a reakcióút ebben az esetben megváltozott.

Lacroix és munkatársai [106] szerint az Y zeolit hordozós Zn katalizátoron a DMC dekarbonilezése során DME és $\mathrm{CO}_{2}$ keletkezik, ami reverzibilis folyamat:

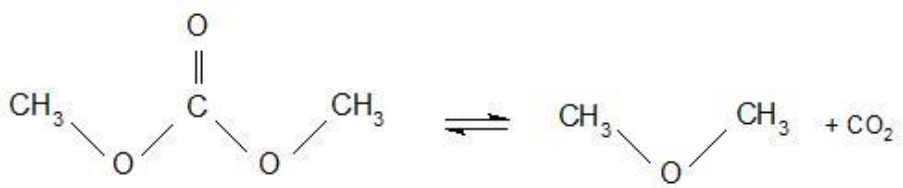

Rámutattak, hogy a reakció kimenetele során a fő befolyásoló tényező a hőmérséklet, ami vagy a karbonát képződése vagy bomlása felé tolja el a reakciót. Alacsonyabb hőmérsékleten a $\mathrm{CO}_{2}$ beékelődése, magasabb hőmérsékleten a $\mathrm{CO}_{2}$ képződése megy 
végbe. [106]. A DMC kitermelést is ehhez az egyensúlyhoz kötötték a DMC direkt szintézise során:

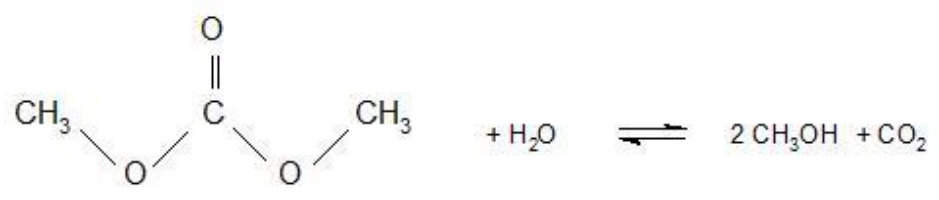

Ezekből az eredményekből arra következtettünk, hogy a redukált $\mathrm{Cu} /$ Norit esetében az DMC dekarbonilezése, amíg az újraoxidált minta esetében a DMC hidrolízise játszódik le.

$\mathrm{Az} \mathrm{NH}_{3}$ és $\mathrm{CO}_{2}$ hőmérséklet programozott deszorpciós mérések a $\mathrm{Cu} / \mathrm{MWCNT}$ és a $\mathrm{Cu} /$ Norit katalizátor esetében hasonlóságot mutattak (19. ábra, 20. ábra, 39. ábra, 40. ábra). Kiindulási állapotban nagy számban voltak savas és bázikus helyek a felületen, a redukálás után ezek azonban alig voltak kimutathatóak. Anderson és munkatársai [77] szerint a DMC bomlása a réz zeolit katalizátoron a részleges $\mathrm{Cu}$ ioncsere eredményeként kialakuló Brönsted savas helyeken megy végbe. A katalizátor redukálásával a savas helyek száma csökkent, mivel a bontás számára rendelkezésre álló aktív centrumok száma is csökkent. Fu és munkatársai [78] összefüggésbe hozták a minták sav-bázis karaktereiét a DMC bomlás során mutatott katalitikus aktivitásukkal. Ugyan a bázikus helyeket is aktívnak vélték ebben a reakcióban, de MgO-on a DMC konverzió alacsonyabb volt, mint a $\mathrm{H}$ ZSM-5 minta esetében, még annak ellenére is, hogy a reakció hőmérséklete $50 \mathrm{~K}$-nel magasabb volt az első esetben.

A redukált minták esetében (19. ábra, 39. ábra) kevés savas helyet találtunk. A DMC bontása során mennyiségük jelentősen megnőtt függetlenül attól, hogy a DMC bomlás mértéke időben állandó vagy csökkenő volt. A hordozó savas karaktere a $\mathrm{Cu} / \mathrm{MWCNT}$ és $\mathrm{Cu} /$ Norit katalizátorok esetében nem meghatározó tényező.

Az XPS mérések szerint a DMC szintézis alatt mind a $\mathrm{Cu} / \mathrm{MWCNT}$, mind a $\mathrm{Cu} / \mathrm{Norit}$ katalizátoron a felületi $\mathrm{Cu}$ oxidálódott, $\mathrm{Cu}^{+}$és $\mathrm{Cu}^{2+}$ egyaránt keletkezett, az utóbbi mennyisége a reakcióidővel nőtt (10. ábra, 32. ábra). A felületi $\mathrm{Cu}$ tartalom ugrásszerủen növekedett az első órában, majd nagyjából változatlan maradt. A 932,3-932,4 eV-os csúcs területe összefüggésben van a felületi $\mathrm{Cu}$ mennyiségével. Feltételezhetö, hogy a $\mathrm{CH}_{3} \mathrm{OH}$ fogyás mértéke függ a felületi $\mathrm{Cu}$ atomok mennyiségétől. A DMC szintézis első perceiben $\mathrm{Cu}^{0}$ volt a felszínen, majd $\mathrm{Cu}^{+}$, ezekben az esetekben DMC nem keletkezett. Elöször a 
$\mathrm{Cu}^{+}$, később a $\mathrm{Cu}^{2+}$ mennyisége is nőtt időben. $\mathrm{A} \mathrm{Cu}^{2+}$ mennyiségének növekedésével a DMC képződése megindult, majd az idő előrehaladtával mennyisége is nőtt. A reakció indukciós periódusában a DMC képződés igen csekély volt (2. ábra, 22. ábra). Ebben a szakaszban rögzített XPS mérések a felületi $\mathrm{Cu}^{+}$és $\mathrm{Cu}^{2+}$ arányainak változását mutatták. Ezekből az eredményekből levonhatjuk azt a következtetést, hogy a DMC szintézis során nem csak a $\mathrm{Cu}$ oxidációs állapota, de azok mennyisége és egymáshoz viszonyított aránya is meghatározó tényező. Amikor a katalizátort az előkezelés után újra oxidáltuk a reakció kezdete elött, a konverzió magasabb volt, de a DMC képződés kezdete eltolódott (24. ábra). Megállapítottuk, hogy egy oxidált felület, amely föként $\mathrm{Cu}^{2+}-\mathrm{t}$ tartalmaz, inaktív katalizátor a DMC szintézisben.

Az említett katalitikus és XPS mérések eredményeinek összevetése alapján arra következtettünk, hogy a DMC és a MF kialakulását az oxidált fém katalizálja, amíg a $\mathrm{CO}_{2}$ termelés erőteljesebb a fém rézen.

A $\mathrm{Cu} / \mathrm{MWCNT}$ mintán és a $\mathrm{Cu} /$ Noriton a $\mathrm{DMC}$ szintézis közben rögzített infravörös mérések során a dimetil-karbonát kimutatható a katalizátor felszínén a reakció alatt (15. ábra, 36. ábra). A Cu/MWCNT reoxidálása után rögzített IR spektrumon megjelenő gyenge abszorpció $3600 \mathrm{~cm}^{-1}$-nél $\mathrm{OH}$ csoporthoz rendelhető, ami a rézhez kötődő metanol disszociációjából keletkező hidrogén reakciója során alakult ki. Bár a metoxi csoportok jelenléte nem egyértelműen bizonyított a reakció közben, de ez magyarázható a nagy reaktivitással és az ebből fakadó alacsony felületi koncentrációval. Jelenléte azonban alátámasztja azt a feltevésünket, amely szerint a metoxi csoportok csak az oxidált fém felületen alakulnak ki. Tehát a reakció első lépése a réz oxidációja, majd ezt követi a metoxi csoportok kialakulása.

A Cu/Noriton a DMC szintézise közben rögzített IR spektrumokon (36. ábra) $2141 \mathrm{~cm}^{-1}$ nél megjelenő sávok a CO-hoz köthetőek. Az XP spektrumok szerint a $\mathrm{Cu}^{+}$és $\mathrm{Cu}^{2+}$ is megjelenik a katalizátor felületén (32. ábra). A fenti abszorpció intenzitása időben csökkent, az XPS eredmények szerint a $\mathrm{Cu}^{2+}$ mennyisége nőtt a felületen, amiből arra következtettünk, hogy a $\mathrm{CO}$ inkább $\mathrm{Cu}^{+}$-hoz, mint a $\mathrm{Cu}^{2+}$-hoz kötődött.

A korábbiakban leírtak szerint a DMC direkt szintézisének katalitikus ciklusa aktív szén hordozós minták esetében a következők szerint épül fel: először kialakulnak a metoxi csoportok, majd a $\mathrm{CO}_{2}$ aktiválódik a fémen, végül a kialakult csoportok reagálnak. A 
hordozó szerepét promóterként említik, amely az aktív fém fajlagos felületének növelésére szolgál [29]. A tiszta hordozók a DMC szintézisében nem voltak aktívak, csak $\mathrm{CO}_{2}$ keletkezett kis mennyiségben. A $\mathrm{Cu} / \mathrm{MWCNT}$ és $\mathrm{Cu} /$ Norit esetében rögzített XP spektrumok bizonyították, hogy nem következett be jelentős változás a hordozók felületén (12. ábra, 34. ábra), bár az O 1s spektrumok enyhe változást mutattak a katalizátor oxigén tartalmában (13. ábra, 35. ábra).

A metanol fogyását vagy a DMC képződési sebességét összefüggésbe hozva az XP spektrumokból meghatározott felületi fém koncentrációval a $\mathrm{Cu} / \mathrm{MWCNT}$ mintán és $\mathrm{Cu} /$ Noriton elért DMC kitermelés sokkal jelentősebb, mint a $\mathrm{Cu}-\mathrm{Ni} / \mathrm{MWCNT}$ mintán és $\mathrm{Cu}-\mathrm{Ni} /$ Noriton (3. táblázat). Kísérleteinkben a DMC kitermelés a $\mathrm{Cu} /$ Norit katalizátoron volt a legmagasabb a közel állandó aktivitású szakaszban atmoszferikus nyomáson. Következésképpen a hordozónak más szerepe is van a reakcióban, mint csak a fajlagos felület növelése. Feltehetőleg a hordozó szerkezete is meghatározó lehet. Az XP spektrumok szerint egyértelmüen ötvözet jött létre a $\mathrm{Cu}-\mathrm{Ni} / \mathrm{MWCNT}$ és $\mathrm{Cu}-\mathrm{Ni} / \mathrm{Norit}$ minták esetében. Feltételezhető, hogy ez az oka a tiszta réz hordozós katalizátoron mértnél alacsonyabb aktivitásnak.

A $\mathrm{Cu}^{+}$ionok aktívak a metanol oxidatív karbonilezésében [107] [31]. Számos munka foglalkozik a DMC képződés mechanizmusával és kinetikájával a CuCl-on [108] [107] [31] vagy a zeolit hordozós $\mathrm{Cu}$ katalizátoron [100]. A DMC kialakulásának két módját feltételezik. Az egyikben a CO beékelödése a dimetoxi csoportokhoz a meghatározó lépés, a másikban pedig a monometil-karbonát (MMC) és a metanol reakciója [100].

A DMC szintézisét $\mathrm{CuCl}_{2}$ tartalmú katalizátorokon tanulmányozták és egy kétlépéses oxidációs-redukciós folyamatot javasoltak. Az első lépés a réz-klorid oxidációja réz metoxi-kloriddá:

$$
\mathrm{CuCl}_{2}+2 \mathrm{CH}_{3} \mathrm{OH} \rightarrow \mathrm{Cu}\left(\mathrm{OCH}_{3}\right) \mathrm{Cl}+\mathrm{CH}_{3} \mathrm{Cl}+\mathrm{H}_{2} \mathrm{O}
$$

A réz metoxi-klorid $\mathrm{CO}$-dal reagálva a $\mathrm{CuCl}_{2}$-ot regenerálta és közben $\mathrm{DMC}$ keletkezett [6] [15] [10]:

$$
2 \mathrm{Cu}\left(\mathrm{OCH}_{3}\right) \mathrm{Cl}+\mathrm{CO} \rightarrow\left(\mathrm{CH}_{3} \mathrm{O}\right)_{2} \mathrm{CO}+2 \mathrm{CuCl}
$$

Sebesség meghatározó lépésként a CO beékelődését adták meg, amely karbonsavmetilésztert eredményezett. Ez a metoxi csoporttal reagálva DMC-ot alkotott [10]. 
Engeldinger és munkatársai azonban feltételezték, hogy a DMC szintézis köztiterméke a MMC [109].

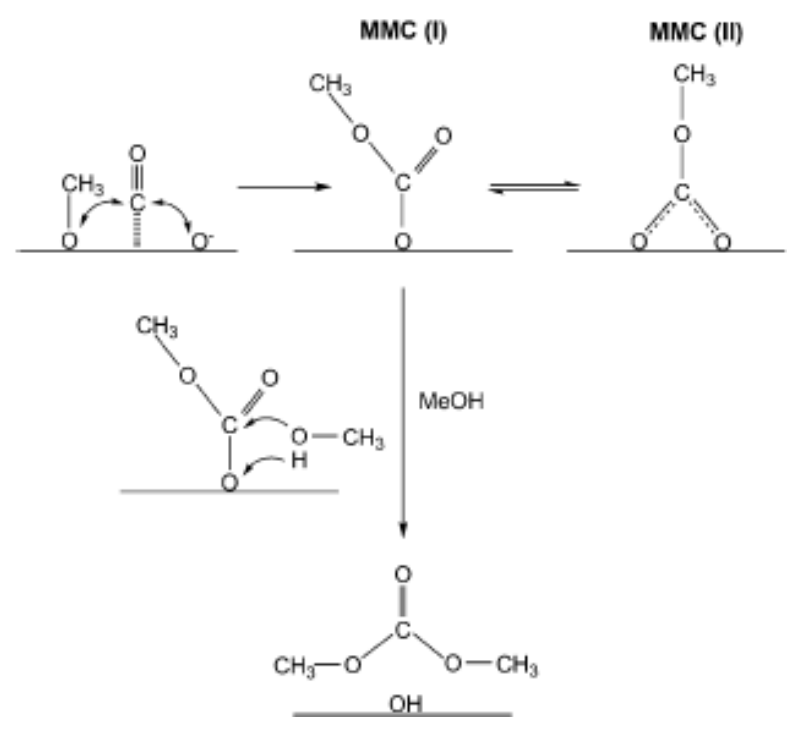

$\mathrm{Az}$ AC felületen végbemenő DMC képződésben elméleti megfontolások alapján a reakció termékek a $\mathrm{Cu}^{0} / \mathrm{AC}$ felületen adszorbeálódnak [74]. A számítások szerint a DMC képződés a MMC és a metanol reakciójának eredménye.

Zhang és munkatársai szerint a $\mathrm{Cu}_{2} \mathrm{O}(111)$ felületen a $\mathrm{CH}_{3} \mathrm{O}$ gátolja a $\mathrm{CO}$ adszorpciót, elősegítve ezzel a $\mathrm{CO}$ beékelődését a metoxi csoportokhoz, tehát a MMC keletkezését. A fő reakcióút alapvetően ezen csoportok reakciója a metoxi csoportokkal, amely végül DMC képződéshez vezet [110].

Irodalmi adatok szerint $\mathrm{Cu}^{2+}$-on vagy fém rézen a $\mathrm{CO}$ adszorpció igen gyenge és reverzibilis $300 \mathrm{~K}$-en és magasabb hőmérsékleten, de a $\mathrm{CO}$ a $\mathrm{Cu}^{+}-h o z$ erősebben kötödik [97]. Hasonlókat tapasztaltak a $\mathrm{CH}_{3} \mathrm{OH}$ és a réz felület kölcsönhatásának vizsgálatakor. Korábban azt találták, hogy a metanol gyenge kölcsönhatásba lép a tiszta $\mathrm{Cu}$ felülettel. Ehhez azonban szükséges volt a felület aktiválása, amely például parciális oxidációval érhető el. 20\%-os felszíni oxigén borítottság szükséges a maximális mértékü metanol adszorpcióhoz [101]. A metanol disszociatívan adszorbeál $\mathrm{Cu}^{+}$-on miközben metoxi csoportok jönnek létre [98]. Megfigyeléseink alapján a metanol és a CO aktiválása ugyanazon a helyen történik, a $\mathrm{Cu}^{+}$-on. $\mathrm{Az}$ eredményeink igazolják az oxidált $\mathrm{Cu}$ alapvető szerepét a DMC szintézis során. Feltehetően a CO beékelődik az adszorbeált metoxi csoportokhoz és így keletkezik a DMC. 
A fent említett DMC szintézis folyamatából méréseink néhány állítást igazolnak, különösen azt, hogy a MMC csoportok a metanollal reagálnak. A metanol disszociatív adszorpciója $\mathrm{Cu}^{+}$-on metoxi csoportok kialakulásával kísérve [98], valamint az erős $\mathrm{CO}$ adszorpció a $\mathrm{Cu}^{+}$-on [97] a vonatkozó irodalomban megtalálható.

Az alábbiakban a DMC szintézis feltételezhető reakcióútja látható, amelyben a megjelenő csoportoknak fontos szerepe van a reakció folyamán:

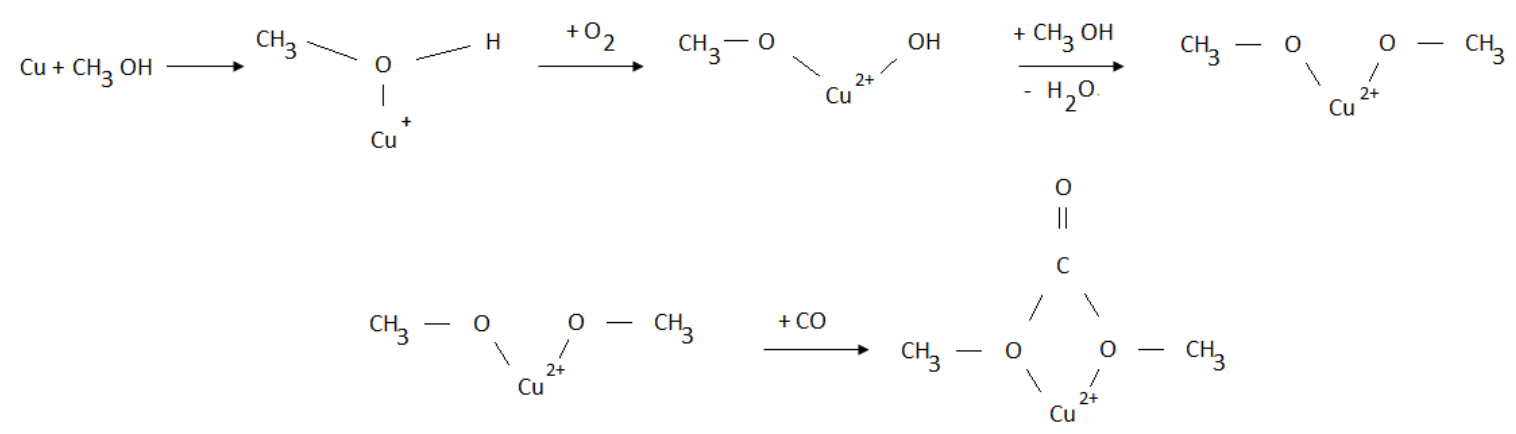

42. ábra A DMC szintézis reakcióútja

A reakció első lépése a réz oxidációja $\mathrm{Cu}^{+}$-ná. Ezt követően a metanol adszorbeálódik a $\mathrm{Cu}^{+}$kationon. Az adszorbeált metanol a reakcióelegy oxigénjével reagálva metoxi csoportot alakít ki, ami a katalizátor rezének tovább oxidálásával jár. A következö lépésben a $\mathrm{CH}_{3} \mathrm{OH}$ molekula víz kiválása mellett olyan kötött formát alakít ki, amely két metoxi csoporttal rendelkezik. A CO beékelödésnek eredménye ehhez a formához vezet, tehát a DMC kialakulásához. Állításainkat az XPS eredmények is alátámasztják, továbbá Zhang és Bell [100] hasonló mechanizmus létezését hangsúlyozta.

A 26. ábra arra utal, hogy a MF képződése másik reakcióúton keresztül is történhet. A katalizátorok O 1s spektruma szerint a felületi karboxil csoportok mennyisége fokozatosan növekszik a reakció elörehaladtával, így az adszorbeált metoxi és karboxil csoportok közvetlen kölcsönhatása eredményezheti a MF képződését. A metanol adszorpció a CuO felületén lévő oxidált $\mathrm{Cu}$-en formiát csoportok kialakulását eredményezi [111], ami metanollal reagálva $\mathrm{MF}$ képződését vagy $\mathrm{CO}_{2}$-dá való bomlását eredményezheti. Ez magyarázhatja a MF képződési sebesség maximum függvény jellegét hőmérséklet és a kontaktidő tekintetében. A MF képződése és bomlása vagy deszorpciója redukálja a $\mathrm{Cu}^{2+}$ centrumokat, amelyeket oxigénnel újra oxidálhatunk. 


\section{7. Összefoglalás}

A zöld kémia a környezetbarát anyagok előállítására és tanulmányozására összpontosít, olyan hosszú távon, gazdaságosan alkalmazható (azaz fenntartható) anyagokat és eljárásokat keresve, amelyek mind kísérleti mind ipari méretekben kivitelezhetőek.

A dimetil-karbonát környezetbarát, nem toxikus, biológiai úton könnyen lebontható vegyület. Sokrétüen felhasználható, kémiai reaktivitása irányítható a reakció körülményeitől függően. Egyre fejlődő előállítási eljárás kialakítása azonban a zöld kémia elvárásainak nem felel meg.

Napjainkban az aktív szén hordozós katalizátorokat előszeretettel használják, hiszen előállítási és beszerzési költségük alacsony. Nagy fajlagos felületük és jó elektromos tulajdonságaik előnyösek a katalitikus reakciókban. A szén hordozós katalizátorokon a DMC szintézise ugyan hatékony, de az irodalomban megtalálható előállítási módok a környezetvédelmi kritériumoknak nem tesznek eleget, például a klorid tartalmú katalizátorok használata miatt sem.

Munkám célja a dimetil-karbonát környezetbarát katalitikus szintézisének fejlesztése volt, alacsony környezeti hatású reagensek használatával, a káros melléktermékek keletkezésének minimalizálásával. Az előállítási lehetőségek közül a metanol oxidatív karbonilezési reakció elemzésével foglalkoztam, amelyet egy áramlásos rendszerben álló ágyas reaktorban, atmoszferikus nyomáson kiviteleztem. A reakciórendszerek komplexitása megkövetelte több párhuzamos kísérletsorozat végrehajtását. A katalizátorok és a felületi folyamatok jellemzését röntgen fotoelektron spektroszkópiás, infravörös spektroszkópiás valamint hőmérséklet programozott deszorpciós vizsgálatokkal végeztük.

A metanol oxidatív karbonilezését az összehasonlíthatóság érdekében megegyező reakciókörülmények között $\mathrm{Cu}, \mathrm{Cu}-\mathrm{Ni}$ és Ni MWCNT és Norit hordozós katalizátoron tanulmányoztuk. Eredményeink szerint a metanol oxidatív karbonilezésében az MWCNT és Norit hordozós $\mathrm{Cu}$ katalizátorok aktívak voltak, így ezek részletes vizsgálatával is foglalkoztunk. A kétfémes katalizátorok használatakor a DMC kitermelés jelentősen kisebb volt, míg a Ni katalizátorok esetében DMC alig keletkezett.

A metanol oxidatív karbonilezése során a $\mathrm{CH}_{3} \mathrm{OH}$ konverzió a $\mathrm{Cu} / \mathrm{MWCNT}$ mintán 4\%, $\mathrm{Cu}-\mathrm{Ni} / \mathrm{MWCNT}$ mintán 3\% volt az állandó aktivitású szakaszban. A Cu/Norit katalizátor 
volt a legaktívabb a metanol oxidatív karbonilezésében. A metanol konverzió 35\% volt a reakció állandó aktivitású szakaszában. A DMC képződése csak egy indukciós periódus után kezdődött, majd megindult a képződése és elérte a közel állandó aktivitású szakaszt. $\mathrm{Az}$ általunk végzett kísérletekben a DMC kitermelés a $\mathrm{Cu} /$ Noriton volt a legmagasabb a közel állandó aktivitású szakaszban, 13,2\%.

A katalizátor eltérő elökezelése különböző hatását gyakorolt a DMC szintézisére a $\mathrm{Cu} /$ Norit esetében. Az alacsonyabb hőmérsékletü redukálás a DMC képződés indukciós idejét elnyújtotta és a DMC szelektivitás az állandó aktivitású szakaszban kisebb volt. Előkezelés nélkül a katalizátor teljesen inaktív volt a DMC szintézisben. Amikor az előkezelés után a katalizátort a reakció előtt oxidáltuk, a DMC képződés indukciós ideje enyhén csökkent.

$\mathrm{Cu} /$ Norit katalizátoron DMC szintézis során a reakció hőmérséklet változtatása eltérö termékeloszlást eredményezett. $\mathrm{A} \mathrm{CO}_{2}$ képződési sebessége folyamatosan emelkedett a hőmérséklet függvényében, de a MF és a DMC képzödési sebesség görbéinek 383 illetve 393 K-nél maximuma volt. Megállapítottuk, hogy a DMC szintézis optimális reakcióhőmérséklete $393 \mathrm{~K}$.

$\mathrm{Cu} /$ Norit katalizátor alkalmazásakor a térsebesség változtatása eltérő hatást gyakorolt a termékeloszlásra a metanol oxidatív karbonilezése során. A DMC és a $\mathrm{CO}_{2}$ képződési sebessége közel lineárisan nőtt a kontaktidő növelésével. Ezzel szemben a MF képződési sebessége maximum görbe szerint változott.

A hőmérséklet programozott DMC bontás során a $\mathrm{Cu} / \mathrm{MWCNT}$ és a $\mathrm{Cu} /$ Norit aktivitása különböző volt. A $\mathrm{Cu} / \mathrm{MWCNT}$ már sokkal alacsonyabb hőmérsékleten aktív volt, mint a $\mathrm{Cu} /$ Norit. Izoterm körülmények között alacsony hömérsékleten mindkét katalizátoron $\mathrm{CO}_{2}$ és DME keletkezett.

Annak ellenére, hogy a savas helyek száma és a BET felület a $\mathrm{Cu} / \mathrm{Norit}$ esetében volt magasabb, mégis a $\mathrm{Cu} / \mathrm{MWCNT}$ bizonyult aktívabbnak a DMC bontásban. Az újra oxidált minták esetében a DMC konverzió magasabb volt, mint a redukált katalizátoron és $\mathrm{Cu}$ /Norit alkalmazásakor a termékösszetétel is megváltozott. A redukált mintán főként DME, míg a reoxidált mintán jellemzően metanol keletkezett. Megállapítottuk, hogy a metanol, az izoterm DMC bontásnál alkalmazott reakciókörülmények között, nem bomlik 
el egyik katalizátor esetében sem. A DMC bomlása során a redukált mintán feltehetőleg a DMC dekarbonilezése játszódik le, míg a reoxidált katalizátoron annak hidrolízise.

$\mathrm{Az} \mathrm{NH}_{3}$ és a $\mathrm{CO}_{2}$ hőmérséklet programozott deszorpciója a $\mathrm{Cu} / \mathrm{MWCNT}$ és a $\mathrm{Cu} / \mathrm{Norit}$ katalizátor esetében hasonlóságot mutattak. A redukált mintákon kevés savas helyet találtunk. A DMC bontása során mennyiségük jelentősen megnőtt függetlenül attól, hogy a DMC bomlás időben állandó vagy csökkenő volt. A hordozó savas karaktere $(\mathrm{Cu} / \mathrm{MWCNT}$ és $\mathrm{Cu} / \mathrm{Norit}$ ) a DMC bomlásában nem meghatározó tényező.

Az XPS vizsgálatok szerint a metanol oxidatív karbonilezése során a $\mathrm{Cu} / \mathrm{MWCNT}$ és a $\mathrm{Cu} /$ Norit katalizátoron a felületi réz a redukció hatására fém rézzé redukálódott. A reakció alatt oxidálódott, $\mathrm{Cu}^{+}$és $\mathrm{Cu}^{2+}$ egyaránt keletkezett, az utóbbi mennyisége a reakcióidővel nőtt. $\mathrm{Cu}$ /Norit esetében a DMC képződése egy hosszabb indukciós szakasz után indult meg, amely alatt rögzített XPS mérések a felületi $\mathrm{Cu}^{+}$és $\mathrm{Cu}^{2+}$ arányainak változását mutatták. Ezekből az eredményekből levonhatjuk azt a következtetést, hogy a DMC szintézis során nem csak a $\mathrm{Cu}$ oxidációs állapota, de azok mennyisége és egymáshoz viszonyított aránya is meghatározó tényező. A kétfémes katalizátorok esetében $\mathrm{Cu}-\mathrm{Ni}$ ötvözet jött létre, ami felelős lehet e katalizátorok gyengébb katalitikus aktivitásáért. Jóllehet az XPS eredmények alapján számított felületi $\mathrm{Cu}$ tartalom mindkét hordozó esetében magasabb volt a kétfémes katalizátoron, a DMC hozam értéke mégis ellentétesen alakult.

Az IR vizsgálatok során a DMC szintézis alatt a $\mathrm{Cu} / \mathrm{MWCNT}$ és a $\mathrm{Cu} /$ Norit esetében is felületen adszorbeálódott DMC jelenlétét mutattuk ki. A Cu/MWCNT esetében rögzített spektrumokból megállapítottuk, hogy metoxi csoportok csak oxidált rézen keletkeznek. A DMC szintézis alatt $\mathrm{Cu} /$ Norit esetében rögzített spektrumokból arra következtettünk, hogy a $\mathrm{CO}$ a katalizátor felületén nagyobb valószínűséggel a $\mathrm{Cu}^{2+}$-hoz kötődik, mint a $\mathrm{Cu}^{+}$-hoz.

$\mathrm{A} \mathrm{Cu} / \mathrm{MWCNT}$ mintán végzett DMC hömérséklet programozott deszorpciója során kapott eredmények szerint az adszorbeált DMC teljesen elbomlott a reakció közben.

$\mathrm{A} \mathrm{Cu} /$ Norit katalizátoron végzett $\mathrm{DMC}$ hőmérséklet programozott deszorpciója során elért eredmények arra utalnak, hogy két különböző DMC adszorpciós hely létezik a katalizátor felületén, amelyek a DMC-ot reverzibilisen kötik meg. A DMC deszorbeálódhat mélyebb rétegekből, vagy a bomlás során keletkező termékekből rekombinálódhat. 
Eredményeink alapján a feltételezhető DMC szintézis első lépése a réz oxidációja $\mathrm{Cu}^{+}$-ná. Ezt követően a metanol adszorbeálódik a $\mathrm{Cu}^{+}$kationon. Az adszorbeált metanol a reakcióelegy oxigénjével reagálva metoxi csoportot alakít ki, ami a katalizátor rezének tovább oxidálásával jár. A következő lépésben a $\mathrm{CH}_{3} \mathrm{OH}$ molekula víz kiválása mellett olyan kötött formát alakít ki, amely két metoxi csoporttal rendelkezik. A CO beékelődése ehhez a formához vezet, tehát a DMC kialakulásához. 


\section{Summary}

Green chemistry is a new branch of chemistry which focuses on the production and on the research of environmentally friendly materials by sustainable methods on laboratory and industrial scale.

Dimethyl carbonate is an environmentally friendly, non-toxic compound that exhibits versatile and tuneable chemical reactivity, depends on the reaction conditions. However, the methods of production still do not met the criteria of green chemistry.

Today, activated carbon supported catalysts are frequently used because of the associated low production and purchasing costs. The high specific surface area and the good electrical properties are advantageous for catalytic reactions. The synthesis of DMC is highly effective on carbon supported catalysts but the methods found in the literature still not meet the environmental criteria as chloride containing catalysts are still used.

The aim of the dissertation was to contribute to the development of an environmentally friendly catalytic synthesis of dimethyl carbonate by using reagents with lowenvironmental impact and minimizing subsequent harmful by-products. Among the various options for synthesis the methanol oxidative carbonylation was in our focus. The reactions were carried out in a continuous flow system in a fixed bed reactor at atmospheric pressure. The complexity of the reaction systems required that several series of parallel experiments shall be performed. The characterization of the catalysts and surface forms was carried out by X-ray photoelectron and infrared spectroscopy as well as by temperature programmed desorption studies.

To be able to compare the results obtained in the oxidative carbonylation of methanol the reactions were performed on $\mathrm{Cu}, \mathrm{Ni}$ and $\mathrm{Cu}-\mathrm{Ni}$ MWCNT and Norit supported catalysts under the same reaction conditions. According to our results the MWCNT and Norit supported $\mathrm{Cu}$ catalysts were active in the oxidative carbonylation of methanol thus, these were studied in detail. In case of the bimetallic catalysts the DMC yield was significantly lower, while on the Ni catalysts DMC was hardly formed.

In the oxidative carbonylation of methanol the $\mathrm{CH}_{3} \mathrm{OH}$ conversion was $4 \%$ on $\mathrm{Cu} / \mathrm{MWCNT}$ and $3 \%$ on $\mathrm{Cu}-\mathrm{Ni} / \mathrm{MWCNT}$ in the initial stage. In our experiments $\mathrm{Cu} / \mathrm{Norit}$ proved to be the most active catalyst in the oxidative carbonylation of methanol. The 
methanol conversion was $35 \%$ in the steady state of the reaction. The formation of DMC started only after an induction period and after the formation reached a nearly constant stage. The yield of DMC was the highest on $\mathrm{Cu} / \mathrm{Norit}$ near the steady state $13.2 \%$.

The different pre-treatment of the catalysts had diverse impact on the DMC synthesis in case of $\mathrm{Cu} /$ Norit. Reduction at lower temperature resulted in the extension of the induction period for the DMC formation and DMC selectivity was also less at the initial state. Without pre-treatment the catalyst was completely inactive in the DMC synthesis. When, the catalyst was oxidized after the pre-treatment, prior to the reaction, the period of DMC formation induction slightly decreased.

During the DMC synthesis on $\mathrm{Cu} /$ Norit the different reaction temperatures resulted in different product distribution. The formation rate of $\mathrm{CO}_{2}$ gradually increased as a function of the temperature, but the MF and DMC formation rate curves had a maximum at 383 and $393 \mathrm{~K}$. We have found that the optimum reaction temperature is $393 \mathrm{~K}$ for DMC synthesis.

In case of $\mathrm{Cu} /$ Norit catalyst the different space velocity also had impact on the product distribution in the methanol oxidative carbonylation. The $\mathrm{DMC}$ and the $\mathrm{CO}_{2}$ production rate increased nearly linearly with increasing the in contact time. In contrast, the MF formation rate curve went through a maximum.

During the temperature-programmed decomposition of DMC $\mathrm{Cu} / \mathrm{MWCNT}$ and $\mathrm{Cu} / \mathrm{Norit}$ showed different activities. $\mathrm{Cu} / \mathrm{MWCNT}$ was much more active at lower temperature than $\mathrm{Cu} /$ Norit. Under isotherm conditions at low temperature on both catalysts $\mathrm{CO}_{2}$ and $\mathrm{DME}$ were formed.

Despite the fact that the number of acid sites was more and the BET surface area was higher in case of $\mathrm{Cu} / \mathrm{Norit}$ the $\mathrm{Cu} / \mathrm{MWCNT}$ was more active in the DMC decomposition. In the case of re-oxidized samples, the DMC conversion was higher than on the reduced catalyst and on the $\mathrm{Cu} / \mathrm{Norit}$ the product distribution changed as well. On the reduced sample mainly DME, on the reoxidized sample mainly methanol was formed. The methanol, using the same experimental conditions as in the isotherm DMC decomposition, did not decompose on neither of the catalysts. On the reduced sample DMC decarbonylation occurs while on the reoxidized sample the hydrolysis of it. 
$\mathrm{NH}_{3}$ and $\mathrm{CO}_{2}$ temperature-programmed desorption of $\mathrm{Cu} / \mathrm{MWCNT}$ and $\mathrm{Cu} / \mathrm{Norit}$ catalyst showed similarities. On the reduced samples only a few acidic sites were found. During the decomposition of DMC their quantity increased significantly regardless of the DMC decomposition, whether it was constant or decreasing in time. The acidic character of the support $(\mathrm{Cu} / \mathrm{MWCNT}$ and $\mathrm{Cu} /$ Norit catalysts $)$ is not a determining factor in the decomposition of DMC.

According to XPS studies in the case of $\mathrm{Cu} / \mathrm{MWCNT}$ and $\mathrm{Cu} / \mathrm{Norit}$ the copper on the surface of the catalyst was in its metallic form after reduction. $\mathrm{Cu}$ was oxidized during the reaction, $\mathrm{Cu}^{+}$and $\mathrm{Cu}^{2+}$ were both formed, and the amount of the latter increased with reaction time in the methanol oxidative carbonylation. In case of $\mathrm{Cu} / \mathrm{Norit}$ the $\mathrm{DMC}$ formation started after an extended induction period, during which the recorded XPS measurements showed changes in the ratio of surface of $\mathrm{Cu}^{+}$and $\mathrm{Cu}^{2+}$. From these results, we can conclude that in the DMC synthesis not only the formation of the appropriate oxidation state of $\mathrm{Cu}$ was the determining factor but their amount and ratio as well. On the catalysts $\mathrm{Cu}-\mathrm{Ni}$ alloy was formed, which could be responsible for the inferior activity of these catalysts. Although the surface $\mathrm{Cu}$ content calculated from the XPS data was higher for the bimetallic catalysts on both supports, the DMC yield was found to be the opposite.

During the synthesis of DMC on $\mathrm{Cu} / \mathrm{MWCNT}$ and $\mathrm{Cu} /$ Norit the presence of adsorbed DMC was detected on the surface in the IR studies. On the spectra recorded on $\mathrm{Cu} / \mathrm{MWCNT}$ methoxy groups were identified only on oxidized copper. From the spectra recorded during the DMC synthesis on $\mathrm{Cu} /$ Norit it is clear that $\mathrm{CO}$ was found to bind rather to $\mathrm{Cu}^{2+}$ than to $\mathrm{Cu}^{+}$on the surface of the catalyst.

The DMC TPD recorded on Cu/MWCNT showed that the adsorbed DMC completely decomposed during the reaction.

The DMC TPD recorded on Cu/Norit suggested that two different DMC adsorption sites existed on the surface of the catalyst, on which the DMC was adsorbed reversibly. The DMC could desorb from multilayers, or recombine form the products of the decomposition.

Based on our results the first step of the DMC synthesis is probably the oxidation of copper to cuprous ion. Subsequently, methanol adsorbs on the $\mathrm{Cu}^{+}$cations. The adsorbed methanol reacting with the oxygen of the reaction mixture produced methoxy groups, 
leading to further oxidation of the surface copper. The next $\mathrm{CH}_{3} \mathrm{OH}$ molecule develops a new form having two methoxy groups. This step is accompanied by the separation of water. The $\mathrm{CO}$ insertion into this form results in the formation of DMC. 


\section{Köszönetnyilvánítás}

Köszönöm témavezetőmnek, Dr. Erdőhelyi András egyetemi tanárnak és Dr. Kónya Zoltán tanszékvezető egyetemi tanárnak, amiért lehető vétették számomra, hogy kutatásaimat a Fizikai Kémiai és Anyagtudományi Tanszéken végezhessem. Hálás vagyok a sok segítségért, és ösztönzésért, amit az évek során tőlük kaptam. Köszönöm, hogy szakmai irányítással és tanácsokkal mindvégig segítették munkámat.

Köszönettel tartozom László Balázsnak az IR mérésekért és Dr. Oszkó Albertnek az XPS mérésekért. Továbbá köszönöm, hogy alapos és lelkiismeretes munkájukkal segítettek cikkeim és e dolgozat létrejöttében.

Hálával tartozom a volt Szilárdtest és Radiokémiai Tanszék valamennyi munkatársának, amiért az elmúlt évek során kellemes és vidám légkörben dolgozhattunk együtt. Köszönöm Tóth Mariannak, hogy mindig bizalommal fordulhattam hozzá segítségért és tanácsért.

Külön köszönet az egész családomnak és barátaimnak a mindenkori támogatásukért és a belém vetett bizalmukért. Nagyon hálás vagyok szerető szüleimnek, akik mindig mellettem álltak és erejükön felül segítettek mindenben egyetemi és doktori tanulmányaim alatt egyaránt. 


\section{Irodalomjegyzék}

1 P. T. Anastas, J. C. Warner. Green Chemistry: Theory. Oxford University Press, New York, 2000.

2 P. Tundo, P. Anastas, D. Black, J. Breen, T. Collins, S. Memoli, J. Miyamoto, M. Polyakoff, W. Tumas. Pure Appl. Chem., 72 (2000), 1207.

3 P. T. Anastas, T. Williamson. In Designing Chemistry for the Environment. American Chemical Society, 1996.

4 L. B. Wen, C. Y. Xin, S. C. Yang. Appl. Energ., 87 (2010), 115.

5 P. Tudo, M. Selva. Acc. Chem. Res., 35 (2002), 706.

6 N. Keller, G. Rebmann, V. Keller. J. Mol. Catal. A: Chem., 317 (2010), 1.

7 F. Rivetti. C. R. Acad. Sci. II C, 3 (2000), 497.

8 P. Tundo. Pure Appl. Chem., 73 (2001), 1117.

9 Y. Ono. Catal. Today, 35 (1997), 15.

10 D. Delledonne, F. Rivetti, U. Romano. Appl. Catal. A: Gen., 221 (2001), 241.

11 Z. H. Fu, Y. Ono. J. Mol. Catal., 91 (1994), 399.

12 M. E. Jenkin, G. D. Hayman. Atmos. Environ., 33 (1999), 1275.

13 Ono, Y. Appl. Catal. A: Gen., 155 (1997), 133.

14 M. Aresta, M. Galatola. J. Cleaner Production, 7 (1999), 181.

15 U. Romano, R. Tesel, G. Cipriani, L. Micucci. US Patent, 4,218,391 (1980).

16 M. A. Pacheco, C. L. Marshall. Energy \& Fuels, 11 (1997), 2. 
17 H. Miyazaki, Y. Shiomi, S. Fujitsu, K. Masunaga, H. Yanagisawa. US Patent, 4,384,133 (1983).

18 T. Matsuzaki, A. Nakamura. Catal. Surv. Jpn., 1 (1997), 77.

19 W. A. Hoffman. J. Org. Chem., 47 (1982), 5209.

20 S. Fang, K. Fujimoto. Appl. Catal. A: Gen., 142 (1996), 1.

21 K. Tomishige, T. Sakaihori, Y. Ikeda, K. Fujimoto. Catal. Lett., 58 (1999), 225.

22 K. T. Jung, A. T. Bell. Top. Catal., 20 (2002), 97.

23 C. J. Jiang, Y. H. Guo, C. G. Wang, C. W. Hu, Y. Wu, E. B. Wang. Appl. Catal. A: Gen., 256 (2003), 203.

24 M. Aresta, A. Dibenedetto, C. Pastore, C. Cuocci, B. Aresta, S. Cometa, E. De Giglio. Catal. Today, 137 (2008), 125.

25 Y. Yoshida, Y. Arai, S. Kado, K. Kunimori, K. Tomishige. Catal. Today, 115 (2006), 95.

26 X. J. Wang, M. Xiao, S. J. Wang, X. Y. Lu, Y. Z. Meng. J. Mol. Catal. A: Chem., 278 (2007), 92.

27 X. L. Wu, Y. Z. Meng, M. Xiao, X. Y. Lu. J. Mol. Catal. A: Chem., 249 (2006), 93.

28 J. Bian, M. Xiao, S. J. Wang, Y. Lu, Y. Meng. Appl. Surf. Sci., 255 (2009), 7188.

29 J. Bian, M. Xiao, S. J. Wang, Y. X. Lu, Y. Z. Meng. J. Colloid Interf. Sci., 334 (2009), 50 .

30 J. Bian, X.W. Wie, L. Wang, Z. P. Guan. Chin. Chem. Lett., 22 (2011), 57.

31 K. Tomishige, K. Kunimori. Appl. Catal. A: Gen., 237 (2002), 103.

32 J. Bian, M. Xiao, S. Wang, Y. Lu, Y. Meng. Catal. Com., 10 (2009), 1142. 
33 J. Bian, M. Xiao, S. J. Wang, Y. X. Lu, Y. Z. Meng. Chin. Chem. Lett., 20 (2009), 352.

34 J. Bian, M. Xiao, S. Wang, X. Wang, Y. Lu, Y. Meng. Chem. Eng. J., 147 (2009), 287.

35 J. Bian, X. W. Wei, Y. R. Jin, L. Wang, D. C. Luan, Z. P. Guan. Chem. Eng. J, 165 (2010), 686.

36 G. L. Curnutt. The Dow Chemical Company, US Patent, 5,004,827 (1991).

37 A. Emmons, J. Gilpin. US Patent, 3,803,201 (1974).

38 I. V. Fernandez. US Patent, 7,803,961 (2010).

39 H. Osora, K. Kobayashi, Y. Seiki, T. Yasutake, M.i lijima, A. Oguchi. US Patent, 7,674,742 (2010).

40 H. Y. Zheng, J. Ren, Y. Zhou, Y. Y. Niu, Z. Li. J. Fuel Chem. Technol., 39 (2011), 282.

41 J. Ren, S. Liu, Z. Li, X. Lu, K. Xie. Appl. Catal. A: Gen., 366 (2009), 93.

42 M. Iwamoto, H. Hamada. Catal.Today, 10 (1991), 57.

43 C. Torre-Abreu, M. F. Ribeiro, C. Henriques, F. R. Ribeiro. Appl. Catal. B: Environ., 13 (1997), 251.

44 A. J. Hernandez-Maldonado, R. T. Yang. J. Am. Chem. Soc., 126 (2004), 992.

45 A. Takahashi, R. T. Yang, C. L. Munson, D. Chinn. Langmuir, 17 (2001), 8405.

46 King, S. T. J. Catal., 161 (1996), 530.

47 M. Richter, M. J. G. Fait, R. Eckelt, E. Schreier, M. Schneider, M.-M. Pohl, R. Fricke. Appl. Catal. B: Environ., 73 (2007), 269.

48 M. Richter, M. J. G. Fait, R. Eckelt, M. Schneider, J. Radnik, D. Heidemann, R. Fricke. J. Catal., 245 (2007), 11. 
49 J. K. Nam, M. J. Choi, D-H. Cho, J. K. Suh, S. B. Kim. J. Mol. Catal. A: Chem., 370 (2013), 7 .

50 S. T. Anderson, T. W. Root. J. Catal., 217 (2003), 396.

51 S. T. Anderson, T. W. Root. J. Mol. Catal. A: Chem., 220 (2004), 247.

52 Y. Zhang, I. J. Drake, D. N. Briggs, A. T. Bell. J. Catal., 244 (2006), 219.

53 R. Wang, Z. Li. Chin. J. Catal., 35 (2014), 134.

54 M. S. Dresselhaus, G. Dresselhaus, Ph. Avouris. Top. Appl. Phys., 80 (2001), 391.

55 E. Auer, A. Freund, J. Pietsch, T. Tacke. Appl. Catal. A: Gen., 173 (1998), 259.

56 W. Li, C. Han, W. Liu, M.H. Zhang, K.Y. Tao. Catal. Today, 125 (2007), 278.

57 P. Serp, M. Corrias, P. Kalck. Appl. Catal. A: Gen., 253 (2003), 337.

58 J. M. Nhut, L. Pesant, J. P. Tessonnier, G. Wine, J. Guille, C. P. Huu, M. J. Ledoux. Appl. Catal. A: Gen., 254 (2003), 345.

59 R. Barthos, F. Solymosi. J. Catal., 249 (2007), 289.

60 R. Barthos, A. Széchenyi, Á. Koós, F. Solymosi. Appl. Catal. A: Gen., 327 (2007), 95.

61 F. Solymosi, R. Barthos, A. Kecskeméti. Appl. Catal. A: Gen., 350 (2008), 30.

62 G. Marbán, A. López, I. López, T. V. Solís. Appl. Catal. B: Environ., 99 (2010), 257.

63 P. Tolmacsov, A. Gazsi, F. Solymosi. Appl. Catal. A: Gen., 362 (2009), 58.

64 T. C. Liu, C. S. Chang. J. Chin. Inst. Chem. Eng., 38 (2007), 29.

65 K. Tomishige, T. Sakaihori, S. Sakai, K. Fujimoto. Appl. Catal. A: Gen., 181 (1999), 95.

66 J. Ren, C. Guo, L. Yang, Z. Li. Chin. J. Catal., 34 (2013), 1734. 
67 M. S. Han, B. G. Lee, I. Suh, H. S. Kim, B. S. Ahn, S. I. Hong. J. Mol. Catal. A: Chem., 170 (2001), 225.

68 M. S. Han, B. G. Lee, B. S. Ahn, H. S. Kim, D. J. Moon, S. I. Hong. J. Mol. Catal. A: Chem., 203 (2003), 137.

69 G. Zhang, Z. Li, , H. Zheng, T. Fu, Y. Ju, Y. Wang. Appl. Catal. B: Environ., 179 (2015), 95.

70 M. S. Han, B. G. Lee, B. S. Ahn, D. J. Moon, S. I. Hong. Appl. Surf. Sci., 211 (2003), 76.

71 Y. Yamamoto, T. Matsuzaki, K. Ohdan, Y. Okamoto. J. Catal., 161 (1996), 577.

72 V. V. Kriventsov, O. V. Klimov, O. V. Kikhtyanin, K. G. Ione, D. I. Kochubey. Nucl. Instrum. Meth. A, 448 (2000), 318.

73 A. Punnoose, M. S. Seehra, B. C. Dunn. E. M. Eyring, Energ. Fuels, 16 (2002), 182.

74 J. Ren, W. Wang, D. Wang, Z. Zuo, J. Lin, Z. Li. Appl. Catal. A: Gen., 472 (2014), 47.

75 J. G. M.-S. Monteiro, O. Q. F. Araújo, J. L. Medeiros. Clean Techn. Environ. Policy, 11 (2009), 209.

76 B. A. V. Santosa, V. M. T. M. Silva, J. M. Loureiro, D. Barbosa, A. E. Rodrigues. Fluid Phase Equilibr., 336 (2012), 41.

77 S. A. Anderson, S. Manthata, T. W. Root. App. Catal. A: Gen., 280 (2005), 117.

78 Y. Fu, H. Zhu, J. Shen. Thermochimica Acta, 434 (2005), 88.

79 K. Niesz, A. Siska, I. Vesselényi, K. Hernadi, D. Méhn, G. Galbács, Z. Kónya, I. Kiricsi. Catal. Today, 76 (2002), 3.

80 Handbook of Auger Electron Spectroscopy. Physical Electronics Ind., 1976.

81 G. Pótári. Katalizátorok felületének jellemzése. SZTE TTIK, 2014. 
82 E. T. Saw, U. Oemar, X. R. Tan, Y. Du, A. Borgna, K. Hidajat, S. Kawi. J. Catal., 314 (2014), 32 .

83 P. F. Barbieri, A. de Siervo, M. F. Carazzolle, R. Landers, G. G. Kleiman. J. Electron Spectrosc. Relate Phenom., 135 (2004), 113.

84 J. L. Figueiredo, M. F. R. Pereira, M. M. A. Freitas, J. J. M. Órfão. Carbon, 37 (1999), 1379 .

85 M. Polovina, B. Babic, B. Kaluderovic, A. Dekanski. Carbon, 35 (1997), 1047.

86 L. Guczi, G. Stefler, O. Geszti, I. Sajó, Z. Pászti, A. Tompos, Z. Schay. Appl Catal A: Gen., 375 (2010), 236.

87 V.I. Nefedov, E. K. Zhumadilov, T. Y. Kopytova. J. Struct. Chem. USSR, 18 (1977), 692.

88 J. P. Tobin, W. Hirschwald. Appl Surf. Sci., 16 (1983), 441.

89 P. B. Kar, N. Ramanathan, K. Sundararajan, K. S. Viswanathan. J. Mol. Struct., 1024 (2012), 84 .

90 H. Bohets, B. J. van der Veken. Phys. Chem. Chem. Phys., 1 (1999), 1817.

91 Wilmhurst, J. K. J. Mol. Spectrosc., 1 (1957), 201.

92 B. A. Sexton, A. E. Hughes N. R. Avery. Surf. Sci., 155 (1985), 366.

93 D. M. Monti, N. W. Cant, D. L. Trimm, M. S. Wainwright. J. Catal., 100 (1986), 17.

94 B. Zhang, G. Ding, H. Zheng, H. Zhu. Appl Catal B: Environ., 152 (2014), 226.

95 A. M. Puziy, O. I. Poddubnaya, R. P. Socha, J. Gurgul, M. Wisniewski. Carbon, 46 (2008), 2113.

96 M. S. Sánchez, A. M. Valiente, A.G. Ruiz, D. M. Nevskaia. J Colloid Interface Sci., 343 (2010), 194. 
97 A. Dandekar, M. A. Vannice. J Catal., 178 (1998), 621.

98 J. Engeldinger, C. Domke, M. Richter, U. Bentrup. Appl Catal A: Gen., 382 (2010), 303.

99 J. W. London, A. T. Bell. J Catal., 31 (1973), 32.

100 Y. Zhang, A. T. Bell. J Catal., 255 (2008), 153.

101 I. E. Wachs, R. J. Madix. J Catal., 53 (1978), 208.

102 S. D. Lin, H. Cheng, T. C. Hsiao. J Mol Catal A: Chem., 342 (2011), 35.

103 J. P. Camplin, E. M. McCash. Surf Sci., 360 (1996), 229.

104 M. Zhang, M. Xiao, S. Wang, D. Han, Y. Lu. J. Cleaner Production, 103 (2015), 847.

105 Y. Zhou, S. Wang, M. Xiao, D. Han, Y. Lu. J. Cleaner Prod. , 103 (2015), 925.

106 J. F. Lacroix, A. Soldera, L. M. Lavoie. J CO2 Utilization, 7 (2014), 46.

107 Z. Li, K. Su, B. Cheng, J. Ming, L. Zhang, Y. Xu. Catal. Commun., 12 (2011), 932.

108 A. B. Shivarkar, S. P. Gupte, R. V. Chaudhari. J. Mol. Catal. A: Chem. 2005, 226, 49, 226 (2005), 49.

109 J. Engeldinger, M. Richter, U. Bentrup. Phys. Chem. Chem. Phys., 14 (2012), 2183.

110 R. Zhang, L. Song, B. Wang, Z. Li. J. Comput. Chem., 33 (2012), 1101.

111 S. Poulston, E. Rowbotham, P. Stone, P. Parlett, M. Bowker. Catal. Lett., 52 (1998), 63. 